\title{
Reference Tables for the Pt-30 Percent Rh Versus Pt-6 Percent Rh Thermocouple
}

\author{
George W. Burns and John S. Gallagher \\ Institute for Basic Standards, National Bureau of Standards, Washington, D.C.
}

(December 9, 1965)

\begin{abstract}
Reference tables for the platinum-30 percent rhodium versus platinum- 6 percent rhodium thermocouple have been established for the range 0 to $1820^{\circ} \mathrm{C}$ based upon the calibrations of thermocouples furnished by three manufacturers in the United States and by one European manufacturer. The thermocouples were calibrated by comparison with standard instruments such as platinum resistance thermometers, platinum-10 percent rhodium versus platinum thermocouples and optical pyrometers. The test procedures and facilities used for the calibrations are described and the accuracy of the measurements is discussed. The platinum-rhodium elements of the thermocouples were examined by a general qualitative spectrochemical method and the results of the analyses are given. Tables of emf of the individual elements of the thermocouple versus $\mathrm{Pt}-27$ for the range 0 to $1500^{\circ} \mathrm{C}$ are also presented. In addition, the effect of variations in the alloying percentages of platinum and rhodium on the temperature-emf relationships of the elements are shown. The results of calibrations for other Pt-30 percent $\mathrm{Rh}$ versus Pt-6 percent $\mathrm{Rh}$ thermocouples, which were received for routine calibration at NBS during the period from May 1963 to March 1965, are also shown.
\end{abstract}

Key Words: Accuracy, calibration, emf, platinum-rhodium elements, platinum-30 percent rhodium versus platinum- 6 percent rhodium, reference tables, spectrochemical analyses, thermocouple.

\section{Introduction}

Studies by Ehringer [1] ${ }^{1}$ and by Walker, Ewing, and Miller [2, 3], have demonstrated that thermocouples in which both legs are platinum-rhodium alloys are capable of reliable temperature measurements at high temperatures. Such thermocouples have been shown to offer the following distinct advantages over the more familiar platinum-10 percent rhodium versus platinum and platinum-13 percent rhodium versus platinum thermocouples at high temperatures: (1) improved stability, (2) increased mechanical strength, and (3) higher operating temperature. The three most common platinum-rhodium combinations in use today are the platinum-20 percent rhodium versus platinum5 percent rhodium, or $20-5$ thermocouple; the platinum-30 percent rhodium versus platinum-6 percent rhodium, or 30-6 thermocouple; and the platinum- 40 percent rhodium versus platinum-20 percent rhodium, or 40-20 thermocouple. The temperature-emf curves for these thermocouples and the more familiar Pt-10 percent $R h$ versus $P t$ and $P t-13$ percent $R h$ versus $P t$ thermocouples are shown in figure 1.

'Figures in brackets indicate the literature references at the end of this paper.

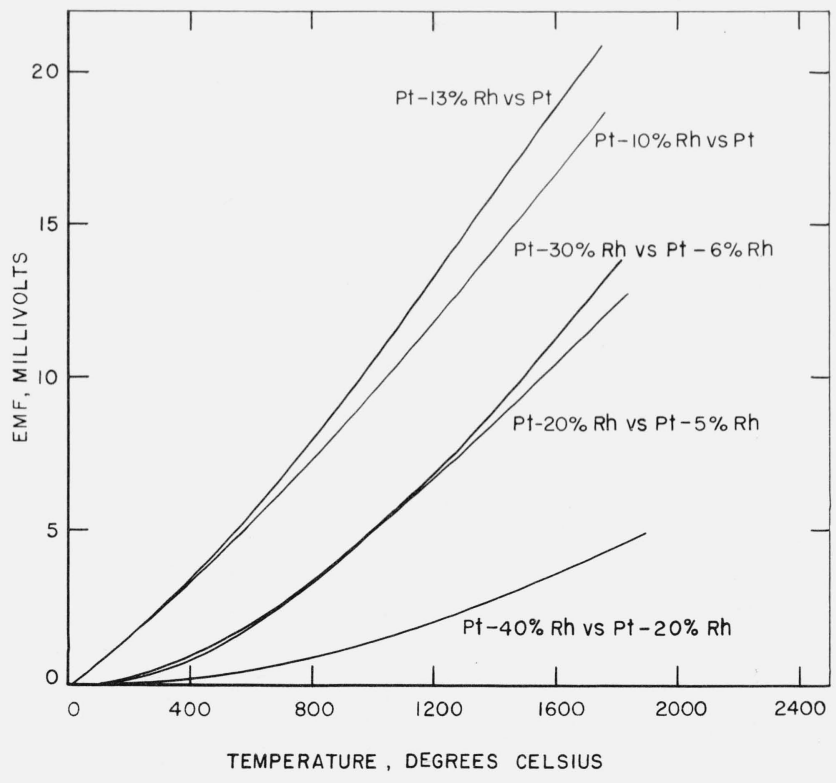

Figure 1. Temperature-emf curves for platinum-rhodium thermocouples, reference junctions at $0{ }^{\circ} \mathrm{C}$. 
Of the three platinum-rhodium combinations the 30-6 thermocouple offers the most favorable overall characteristics. Although the thermoelectric characteristics of the 30-6 thermocouple and the 20-5 thermocouple are similar, the 30-6 thermocouple does offer a slightly greater thermoelectric power at the higher temperatures and it also has a somewhat higher tensile strength than the 20-5 thermocouple. The 40-20 thermocouple is a special combination intended primarily for use in the 1700 to $1850{ }^{\circ} \mathrm{C}$ range [4]. Even though the 40-20 thermocouple may be used at slightly higher temperatures than the 30-6 thermocouple, its relatively low thermoelectric power limits its usefulness at lower temperatures.

Studies made with the 30-6 thermocouple have shown it can be used intermittently (for several hours) up to $1800{ }^{\circ} \mathrm{C}$ and continuously (for several hundred hours) at temperatures up to about $1750{ }^{\circ} \mathrm{C}$ with only small changes in calibration. The maximum temperature limit for the thermocouple is governed, primarily, by the liquidus of the Pt-6 percent $\mathrm{Rh}$ element which is estimated to be about $1820{ }^{\circ} \mathrm{C}[5]$. The thermocouple is most reliable when used in a clean oxidizing atmosphere (air) but has also been used with some success in neutral atmospheres [2] and vacuum $[3,6]$. The stability of the thermocouple at high temperatures has been shown [2] to depend, primarily, upon the quality of the materials used for protecting and insulating the thermocouple. High purity alumina with low iron-content appears to be the most suitable material available today for the purpose.

The 30-6 thermocouple was first introduced in Europe by Degussa, Hanau, Germany. Recently a reference curve for the thermocouple was published by Obrowski and Prinz [7] of the Degussa Laboratories. The curve, which is represented by a set of cubic equations, was developed by determining the emfs of numerous Degussa thermocouples at various thermometric fixed points. This curve is often referred to as the new Degussa curve since it replaces an older curve formerly used with the Degussa thermocouples. The emfs of the old and new Degussa reference curves [7] are given at $100 \mathrm{deg}$ intervals in table 1 for the range 0 to $1800^{\circ} \mathrm{C}$.

Because of its favorable characteristics, the 30-6 thermocouple has rapidly gained acceptance and become more widely used in this country. Consequently, the National Bureau of Standards was requested by the American Society for Testing and Materials, Committee E-20, Subcommittee IV to prepare reference tables for the thermocouple to facilitate its use and calibration. A testing program was initiated by the Temperature Section at NBS for this purpose. In this program thermocouples were obtained from three manufacturers in the United States and from one European manufacturer and were calibrated by conventional methods of test. The methods included calibration by comparison with standard instruments, such as platinum-10 percent rhodium versus platinum thermocouples, platinum resistance thermometers, and optical pyrometers, and the determination of the emfs of the individual elements of the thermocouples against the platinum thermoelectric standard maintained at NBS known as Pt-27. These methods of test are discussed in NBS Circular 590. Reference tables for the 30-6 thermocouple were calculated from the results of the calibrations and the tables are presented in the appendix of this paper. The temperature-emf relationship given by the reference tables is believed to be representative of materials being produced by manufacturers in this country at the present time.

TABLE 1. Emf of old and new Degussa reference curves for the 30-6 thermocouple

\begin{tabular}{c|r|r}
\hline \hline & \multicolumn{2}{|c}{ Emf } \\
Temperature & \multicolumn{2}{|c}{} \\
& & \\
(Int. 1948) & Old curve & New curve \\
\hline & & \\
${ }^{\circ} \mathrm{C}$ & $m V$ & $m V$ \\
0 & 0.000 & 0.000 \\
100 & .056 & .033 \\
200 & .162 & .177 \\
300 & .419 & .430 \\
400 & .790 & .789 \\
500 & 1.245 & 1.247 \\
600 & 1.796 & 1.795 \\
700 & 2.442 & 2.433 \\
800 & 3.162 & 3.159 \\
900 & 3.964 & 3.966 \\
1000 & 4.839 & 4.847 \\
1100 & 5.791 & 5.795 \\
1200 & 6.811 & 6.806 \\
1300 & 7.890 & 7.871 \\
1400 & 9.000 & 8.977 \\
1500 & 10.130 & 10.113 \\
1600 & 11.260 & 11.267 \\
1700 & 12.390 & 12.428 \\
1800 & 13.520 & 13.583 \\
& & \\
\hline
\end{tabular}

Some of the preliminary work in the reference table program, concerned with the selection of thermocouple materials, was described in a previous paper [8]. The testing procedures and methods used in the program were also discussed in the previous paper but are described again in this paper in more detail.

\section{Thermocouple Materials}

\subsection{Thermocouple Materials Used in the Preparation of the Reference Table}

Thermocouple materials were supplied by three American manufacturers; (1) Engelhard Industries, Inc., (2) Sigmund Cohn Corporation, (3) J. Bishop and Company, and by one European manufacturer, Degussa, Hanau, Germany. A length of 0.020 in. (nominal) diameter wire, between 9 and $10 \mathrm{ft}$ long, of both the Pt-6 percent Rh and the Pt-30 percent Rh alloy was furnished by each manufacturer. The alloy wires supplied by the American manufacturers were fabricated to have compositions of Pt-6.12 percent Rh and $\mathrm{Pt}-29.60$ percent $\mathrm{Rh}$ [8]. The alloy wires submitted by Degussa were taken from stock and were reported to have nominal compositions of Pt-6.15 percent $\mathrm{Rh}$ and $\mathrm{Pt}-29.50$ percent $\mathrm{Rh}^{2}$

${ }^{2}$ For convenience in the ensuing discussion and presentation of the test results the platinum-rhodium wires submitted by Degussa will be referred to as Pt-6.12 percent Rh and $\mathrm{Pt}-29.60$ percent $\mathrm{Rh}$ alloys. 
Eleven thermocouples were prepared from the alloy wires supplied, three thermocouples from each of the American manufacturers and two thermocouples from Degussa. For purposes of this report, letter designations $\mathrm{A}, \mathrm{B}$, and $\mathrm{C}$ are assigned to the three American manufacturers (in an arbitrary way), and D is assigned to Degussa. The thermocouples of the various manufacturers are identified as shown in table 2.

TABLE 2. Description of thermocouples used in preparation of reference table

\begin{tabular}{c|c|c}
\hline $\begin{array}{c}\text { Manufacturer } \\
\text { designation }\end{array}$ & $\begin{array}{c}\text { Thermocouple } \\
\text { identification }\end{array}$ & Material received \\
\hline A & A1, A2, A3 & Jan. 1963 \\
B & B1, B2, B3 & Dec. 1962 \\
C & C1, C2, C3 & Jan. 1963 \\
D & D1, D2 & Oct. 1962 \\
\hline
\end{tabular}

Samples of the platinum-rhodium wires submitted by manufacturers A, B, C, and D were examined by a general qualitative spectrochemical method ${ }^{3}$ and the results of the analyses are given in table 3 . The results of an analysis for a thermocouple quality (reference grade) platinum wire are also shown for purposes of comparison. groups of 0.020 in. diam platinum-rhodium wires were supplied by manufacturer B for study. The two groups consisted of one group of wires with rhodium percentages of $5.90,5.95,6.00,6.05$, and 6.10 and a second group of wires with rhodium percentages of $29.50,29.75,30.00$, and 30.25 . Also, during the period of test program, a number of 30-6 thermocouples were submitted by industrial users and thermocouple manufacturers for routine calibration. The results of the calibrations for some of the thermocouples submitted will be discussed in this paper. In most cases the manufacturers of these thermocouples were known. Some descriptive information about the thermocouples to be discussed is given in table 4 .

TABLE 4. Description of other thermocouples

\begin{tabular}{c|c|c|c}
\hline \hline Manufacturer a & $\begin{array}{c}\text { Approximate } \\
\text { wire diameter }\end{array}$ & $\begin{array}{c}\text { Thermocouple } \\
\text { identification }\end{array}$ & $\begin{array}{c}\text { Material } \\
\text { received }\end{array}$ \\
\hline & inches & & \\
$\mathrm{A}$ & 0.025 & $\mathrm{~A} 11$ & Jan. 1964 \\
$\mathrm{A}$ & .020 & $\mathrm{~A} 22$ & Mar. 1965 \\
$\mathrm{B}$ & .020 & B11 & Dec. 1963 \\
$\mathrm{B}$ & .032 & B22 & May 1964 \\
$\mathrm{C}$ & .020 & $\mathrm{C} 11$ & Oct. 1963 \\
D & .020 & D11 & Oct. 1964 \\
D & .020 & D22 & Oct. 1964 \\
E & .020 & E11 & May 1963 \\
Unknown & .025 & X11 & Oct. 1963 \\
\hline
\end{tabular}

a In cases where two thermocouples from the same manufacturer are listed, the thermocouples are from different lots.

מManufacturer: Johnson Matthey and Company, London, England.

TABLE 3. Results of spectrochemical analyses of platinum-rhodium thermoelements

\begin{tabular}{|c|c|c|c|c|c|c|c|c|c|}
\hline \multirow{2}{*}{$\begin{array}{l}\text { Elements } \\
\text { detected }\end{array}$} & \multicolumn{2}{|c|}{ Manufacturer A } & \multicolumn{2}{|c|}{ Manufacturer B } & \multicolumn{2}{|c|}{ Manufacturer C } & \multicolumn{2}{|c|}{ Manufacturer D } & \multirow{2}{*}{$\begin{array}{c}\text { Reference } \\
\text { grade } \\
\text { platinum }\end{array}$} \\
\hline & $\begin{array}{c}\text { Pt-6.12\%Rh } \\
\text { element }\end{array}$ & $\begin{array}{c}\mathrm{Pt}-29.60 \% \mathrm{Rh} \\
\text { element }\end{array}$ & $\begin{array}{c}\text { Pt-6.12\%Rh } \\
\text { element }\end{array}$ & $\begin{array}{c}\text { Pt.29.60\%Rh } \\
\text { element }\end{array}$ & $\begin{array}{c}\text { Pt-6.12\%Rh } \\
\text { element }\end{array}$ & $\begin{array}{c}\text { Pt-29.60\%Rh } \\
\text { element }\end{array}$ & $\begin{array}{c}\text { Pt-6.12\%Rh } \\
\text { element }\end{array}$ & $\begin{array}{c}\mathrm{Pt}-29.60 \% \mathrm{Rh} \\
\text { element }\end{array}$ & \\
\hline $\mathrm{Ag}$ & $-?$ & $-?$ & $-?$ & $-?$ & - ? & - ? & - ? & - ? & - ? \\
\hline $\mathrm{Al}$ & - & $-\bar{v}$ & - & $\mathrm{w}$, & - & - & - & $-\overline{\mathrm{V}}$ & - \\
\hline $\begin{array}{l}\mathrm{Au} \\
\mathrm{B}\end{array}$ & -? & $\begin{array}{l}\text { FW } \\
\text { FT }\end{array}$ & -? & -? & -? & $\overrightarrow{\mathrm{FT}}$ & -? & VW & -? \\
\hline $\mathrm{Ca}$ & - & $\mathrm{T}$ & - & - & - & $\mathrm{T}$ & 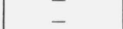 & FT & - \\
\hline $\mathrm{Cu}$ & FT & $T^{1}$ & FT & FT & FT & FT & FT & $\mathrm{T}$ & $\mathrm{T}$ \\
\hline $\mathrm{Fe}$ & VW & W & FT & VW & ${ }_{T}^{1}$ & VW & ${ }_{T}^{1}$ & W & - \\
\hline $\begin{array}{l}\mathrm{re} \\
\mathrm{Ir}\end{array}$ & _o & $\mathrm{W}$ & - & VW & -1 & VW & ${ }_{-}^{1}$ & W & - \\
\hline $\mathrm{Mg}$ & $-?$ & $\mathrm{~T}$ & - & - & $\mathrm{T}$ & - & $V W$ & $\mathrm{~T}$ & - \\
\hline $\mathrm{Ni}$ & - & - & $-\overline{y X}$ & $-?$ & - & $\overline{\mathrm{V}}$ & - & $-{ }_{W}$ & - \\
\hline $\mathrm{Pt}$ & vs & VS & VS & VS & vS & VS & vS & $\mathrm{vS}$ & $\overline{v S}$ \\
\hline $\mathrm{Rh}$ & $\mathrm{S}$ & vS & $\mathrm{s}$ & vS & $\mathrm{s}$ & VS & $\mathrm{s}$ & vS & - \\
\hline $\mathrm{Si}$ & W & $\mathrm{VW}$ & $-?$ & $\mathrm{VW}$ & $\mathrm{VW}$ & $\mathrm{VW}$ & $-?$ & - & - \\
\hline $\mathrm{Tl}$ & $-?$ & - & $-?$ & - & $-?$ & - & $-?$ & - & $-?$ \\
\hline
\end{tabular}

NoTE: In general, VS, greater than $10 \% ; \mathrm{S}, 1-10 \% ; \mathrm{W}, 0.01-0.1 \% ; \mathrm{VW}, 0.001-0.01 \% ; \mathrm{T}, 0.0001-0.001 \%$; FT, less than $0.0001 \%$; not detected; - ?, probably not detected.

\subsection{Other Thermocouples and Thermocouple Materials}

In addition to the materials supplied specifically for purposes of preparing the reference tables, other thermocouples and thermocouple materials were also obtained and various other tests performed. Two

\footnotetext{
${ }^{3}$ Spectrochemical analysis performed by the Spectrochemistry Section of the National Bureau of Standards.
}

\section{Apparatus}

Four stirred liquid baths were used for calibrations in the range 0 to $450{ }^{\circ} \mathrm{C}$. Each of the baths employed a different liquid medium and each was used to cover a separate portion of the temperature range. Temperatures in the stirred liquid baths were determined with a calibrated platinum resistance thermometer. The baths are described in more detail in section 5.1c 
of NBS Monograph 90. Also in the range 0 to $450{ }^{\circ} \mathrm{C}$ and for temperatures up to $1100{ }^{\circ} \mathrm{C}$ a horizontal tube type furnace was used. The furnace has a nickel (80)-chromium (20) tube which serves as a heating element. The tube has an inside diameter of $13 / 16$ in., an outside diameter of $15 / 16 \mathrm{in}$. and is $24 \mathrm{in}$. long. The furnace is described in section 4.1 of NBS Circular 590. Temperatures in the tube furnace were determined with standard $\mathrm{Pt}-10$ percent $\mathrm{Rh}$ versus $\mathrm{Pt}$ thermocouples. The $\mathrm{Pt}-10$ percent $\mathrm{Rh}$ versus $\mathrm{Pt}$ thermocouples were calibrated by the fixed point method (see sections 3 and 5.1 of NBS Circular 590) and met the requirements of the International Practical Temperature Scale of 1948 for standard thermocouples (see NBS Monograph 37). The calibrations of the standard thermocouples above $1063{ }^{\circ} \mathrm{C}$ were extrapolated by the method described in section 5.1 of Circular 590 .

Platinum reference wires were used in the calibrations performed in the stirred liquid baths and the tube furnace, and were also used in several other tests described in the paper. The emf's of the platinum reference wires were known relative to the platinum thermoelectic standard maintained at NBS, known as Standard Pt-27 (see section 7 of NBS Circ. 590).

The emf measurements for the calibrations in the stirred liquid baths in the 0 to $450{ }^{\circ} \mathrm{C}$ range were made with a six dial Rubicon thermal free potentiometer and the resistance measurements of the platinum resistance thermometer were made with a Leeds and Northrup Type G-2 resistance thermometer bridge. In all other tests, the emf measurements were made with Leeds and Northup Type $\mathrm{K}-3$ potentiometers. The $\mathrm{K}-3$ potentiometers were calibrated by comparison with a calibrated six dial precision potentiometer.

In the range 1063 to $1790{ }^{\circ} \mathrm{C}$ blackbodies were used for calibrations by direct comparison with an optical pyrometer. Two blackbodies were fabricated from 4 in. long, round, alumina rods, one with a diameter of $13 / 8$ in. and one with a diameter of $1 \frac{1 / 2}{}$ in. In one end of each rod a $1 / 8$ in. diam axial sight hole was drilled to a depth of $2 \mathrm{in}$. and a $1 / 4 \mathrm{in}$. diam axial hole was drilled in the opposite end of each rod to a depth of $15 / 16$ in. The $1 / 8$ in. diam axial sight holes approximate a blackbody very closely when the walls of the holes are at a uniform temperature. The spectral emissivity of the sight holes at a wavelength of $0.65 \mu$ was assumed to be 1 for measurements described in this paper which involve temperature determinations with an optical pyrometer (see sec. 7 for a discussion of the errors associated with the use of the blackbodies). For convenience, the alumina rods will, henceforth, be referred to as the alumina "blackbodies." A cross section of the $1^{1 / 2}$ in. diam alumina "blackbody" is shown in figure 2 .

The $13 / 8$ in. diam alumina "blackbody" was heated in a high temperature tube furnace. The heating element of the furnace was a silicon carbide tube with an inside diameter of about $13 / 8$ in., and outside diameter of $23 / 8 \mathrm{in}$. and an overall length of $28 \mathrm{in}$. The alumina "blackbody" was located in the furnace at

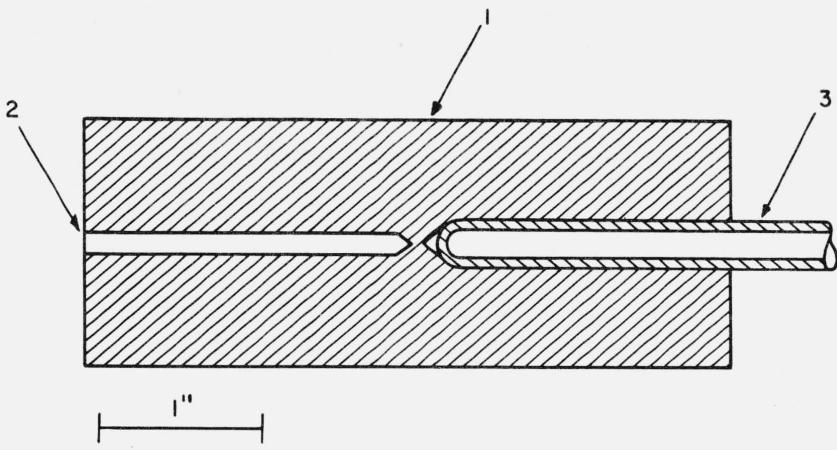

Figure 2. Cross section of alumina "blackbody": (1) alumina rod; (2) blackbody cavity or sight hole; (3) alumina protecting tube.

the center of the silicon carbide tube, and a series of alumina disks was positioned on either side of the rod. The disks served as radiation shields and reduced the power loses out the ends of the furnace. An alumina protecting tube with an o.d. of about $1 / 4$ in. was inserted through central holes in the series of alumina disks and into the $1 / 4 \mathrm{in}$. hole in one end of the alumina "blackbody." A cross section of the furnace is shown in figure 3 .

The 1/2-in. diam alumina "blackbody" was heated in a horizontal wire wound tube furnace. The furnace had three separate heater windings, two end windings, and a center winding of platinum- 40 percent rhodium wire. The windings were wound on an alumina tube which had an inside diameter of about $1 \frac{1 / 2}{2}$. and was $24 \mathrm{in}$. long. The inside of the alumina tube was lined with a Pt-10 percent $\mathrm{Rh}$ tube which was rolled from a piece of sheet stock $0.005 \mathrm{in}$. thick. The alumina "blackbody," alumina disks, and an alumina protecting tube were arranged in the furnace similar to the arrangement used in the silicon carbide tube furnace. A cross section of the wire wound tube furnace is shown in figure 4.

The temperatures of the alumina "blackbodies" were determined with a calibrated Leeds and Northrup Type 8636-C visual optical pyrometer. The optical pyrometer was calibrated by comparison with the NBS visual standard optical pyrometer ${ }^{4}$ using a tungsten strip lamp as a transfer source. The calibration consisted of determining the relationship between the brightness or blackbody temperatures indicated by the instrument and the pyrometer lamp current. The calibration procedure is described in section 5.1 of NBS Monograph 41. In use the current through the pyrometer lamp was controlled with a rheostat and determined by measuring the voltage drop across a $1 \Omega$ standard resistor in series with the lamp. 4 This pyrometer is known as the Fairchild pyrometer and it is described in section 2.2
of NBS Monograph 41 . The calibration and accuracy of the instrument are discussed in section 4 of the Monograph. 


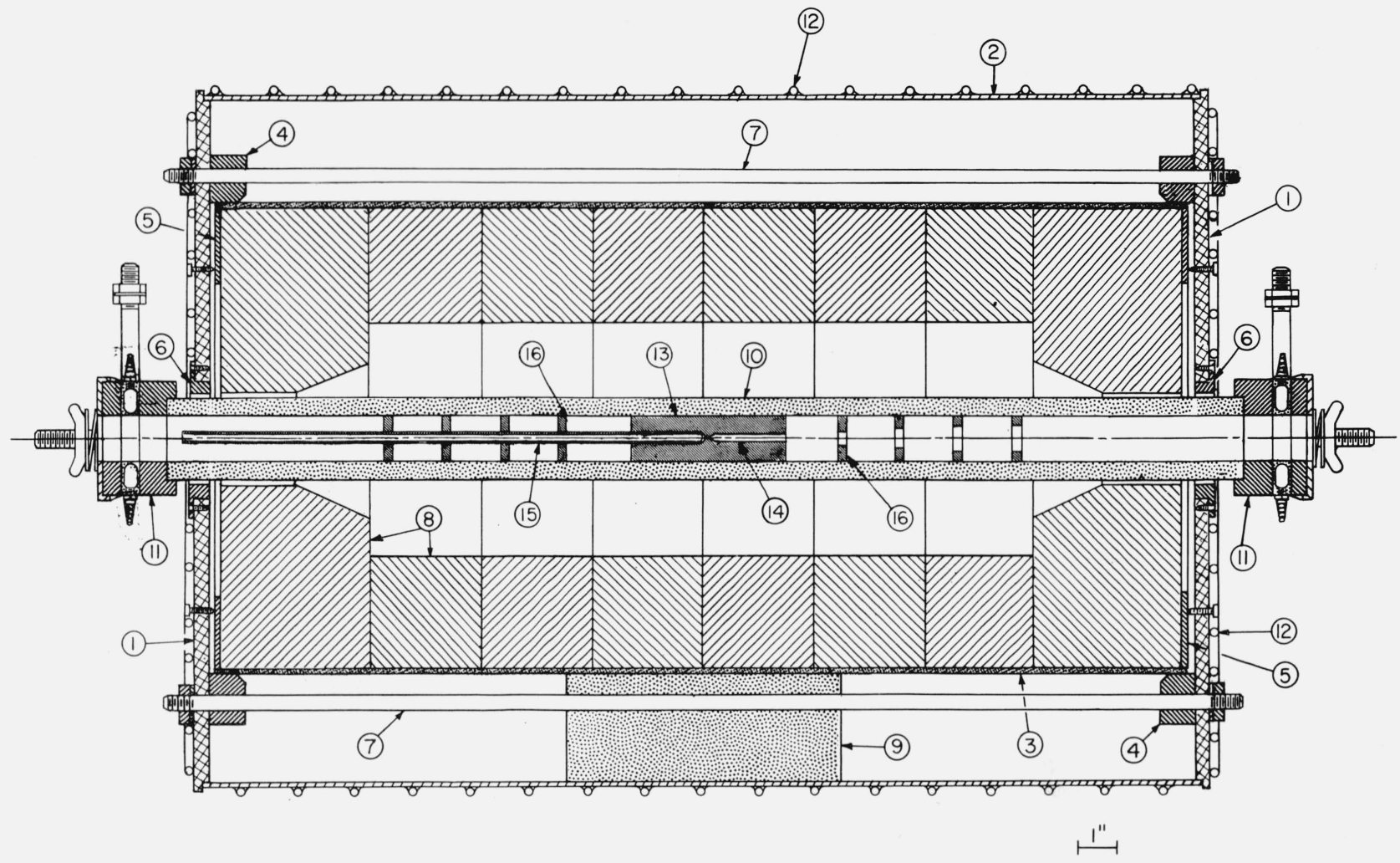

Figure 3. Cross section of silicon carbide tube furnace: (1) brass end plate; (2) brass shell; (3) inconel liner; (4) stainless steel support ring; (5) stainless steel retaining disk; (6) transite insulator ring; (7) inconel tie rod; (8) refractory insulating liner; (9) refractory support; (10) silicon carbide heating tube; (11) terminal assembly; (12) copper tubing; (13) alumina "blackbody"; (14) blackbody cavity or sight hole; (15) alumina protecting tube; (16) alumina disk.

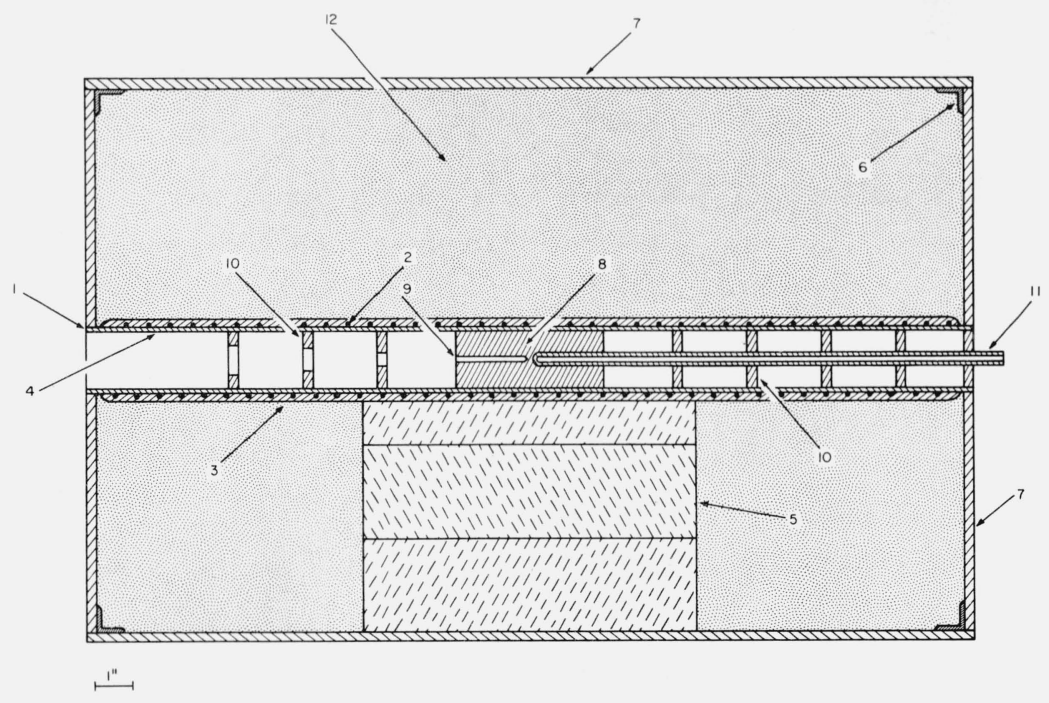

FIgURE 4. Cross section of Pt-Rh wire wound tube furnace: (1) alumina tube; (2) Pt-40 percent Rh winding; (3) alumina cement; (4) 0.005 inch thick Pt-10 percent Rh liner; (5) refractory brick support; (6) steel angle frame; (7) transite shell; (8) alumina "blackbody"; (9) blackbody cavity or sight hole; (10) alumina disk; (11) alumina protecting tube; (12) bubbled alumina insulation. 


\section{Experimental Procedure}

\subsection{Tests of Thermocouples in Table 2}

The platinum-rhodium wires submitted by the four manufacturers were prepared for test by annealing them electrically in air for $1 \mathrm{hr}$ at about $1450{ }^{\circ} \mathrm{C}$. The annealing temperature of the wires was determined with an optical pyrometer, assuming the spectral emissivity of the wires was 0.3 at a wavelength of $0.65 \mu$. The wires were then cut and paired to form the 11 thermocouples listed in table 2. The measuring junctions of the thermocouples were welded with an oxygen-gas torch and the thermocouples were assembled in double bore alumina insulating tubes. The thermocouples were then tested as described in the following sections. The tests are described in the following sections in chronological order and are also summarized in table 5 . All the tests were performed in air, and the reference junctions of the thermocouples and thermoelements were maintained at $0{ }^{\circ} \mathrm{C}$ in ice baths.

TABLE 5. Summary of tests on the thermocouples in table 2

\begin{tabular}{|c|c|c|c|}
\hline Section & $\begin{array}{c}\text { Thermocouple } \\
\text { tested }\end{array}$ & Description of test & $\begin{array}{l}\text { Temperature } \\
\text { reference }\end{array}$ \\
\hline $4.1 \mathrm{a}$ & $\begin{array}{l}\mathrm{A} 1, \mathrm{~A} 2, \mathrm{~A} 3, \mathrm{~B} 1 \\
\mathrm{~B} 2, \mathrm{~B} 3, \mathrm{C} 1, \mathrm{C} 2 \\
\mathrm{C} 3, \mathrm{D} 1 \text { and } \mathrm{D} 2\end{array}$ & $\begin{array}{l}\text { Calibration of thermoelements by } \\
\text { comparison with platinum ref- } \\
\text { erence wires in chromel tube } \\
\text { furnace in } 0 \text { to } 1100^{\circ} \mathrm{C} \text { range. }\end{array}$ & $\begin{array}{c}\mathrm{Pt} \text { versus } \mathrm{Pt}-10 \\
\text { percent } \mathrm{Rh} \\
\text { thermocouple. }\end{array}$ \\
\hline $4.1 \mathrm{~b}$ & $\mathrm{~A} 1, \mathrm{~B} 3$ and $\mathrm{C} 2$ & $\begin{array}{l}\text { Calibration of thermoelements by } \\
\text { comparison with platinum ref- } \\
\text { erence wires in stirred liquid } \\
\text { baths in } 0 \text { to } 4500^{\circ} \mathrm{C} \text { range. }\end{array}$ & $\begin{array}{l}\text { Platinum } \\
\text { resistance } \\
\text { thermometer. }\end{array}$ \\
\hline $4.1 \mathrm{c}$ & $\begin{array}{l}\mathrm{A} 1, \mathrm{~A} 2, \mathrm{~B} 2, \mathrm{~B} 3, \\
\mathrm{C} 1, \mathrm{C} 2, \mathrm{D} 1 \text { and } \\
\mathrm{D} 2\end{array}$ & $\begin{array}{l}\text { Calibration of thermocouples by } \\
\text { direct comparison with optical } \\
\text { pyrometer in range } 1050 \text { to } 1600 \\
{ }^{\circ} \mathrm{C} \text { (thermocouples heated in } \\
\mathrm{SiC} \text { tube furnace). }\end{array}$ & Optical pyrometer. \\
\hline $4.1 d$ & $\begin{array}{l}\text { A1, B2, C1 and } \\
\text { D2 }\end{array}$ & $\begin{array}{l}\text { Calibration of thermoelements by } \\
\text { comparison with platinum ref- } \\
\text { erence wires in range } 1063 \\
\text { to } 1500{ }^{\circ} \mathrm{C} \text {. }\end{array}$ & Thermocouple B3. \\
\hline $4.1 \mathrm{e}$ & $\begin{array}{l}\mathrm{A} 1, \mathrm{~A} 2, \mathrm{~B} 2, \mathrm{~B} 3 \\
\mathrm{C} 1, \mathrm{C} 2, \mathrm{D} 1 \\
\text { and D2 }\end{array}$ & $\begin{array}{l}\text { Calibration of thermocouples } \\
\text { by comparison with } \mathrm{Pt} \text { versus } \\
\mathrm{Pt}-10 \text { percent } \mathrm{Rh} \text { thermo- } \\
\text { couple in range } 1063 \text { to } 1450^{\circ} \mathrm{C} \text {. }\end{array}$ & $\begin{array}{l}\mathrm{Pt} \text { versus } \mathrm{Pt}-10 \\
\text { percent } \mathrm{Rh} \\
\text { thermocouple. }\end{array}$ \\
\hline 4.1f & $\begin{array}{l}\mathrm{A} 2, \mathrm{~A} 3, \mathrm{~B} 1, \mathrm{~B} 3 \\
\mathrm{C} 2, \mathrm{C} 3, \mathrm{D} 1 \\
\text { and D2 }\end{array}$ & $\begin{array}{l}\text { Calibration of thermocouples by } \\
\text { direct comparison with optical } \\
\text { pyrometer in range } 1063 \text { to } \\
1750{ }^{\circ} \mathrm{C} \text { a (thermocouples } \\
\text { heated in Pt-Rh wire wound } \\
\text { tube furnace). }\end{array}$ & Optical pyrometer. \\
\hline
\end{tabular}

a Thermocouples A3, B1, and C3 calibrated to $1790^{\circ} \mathrm{C}$.

a. Tests in Nickel-Chromium Tube Furnace in Range 0 to $1100{ }^{\circ} \mathrm{C}$

In these tests the emf of both thermoelements of each of the eleven thermocouples was determined against platinum reference wires in the horizontal nickel-chromium tube furnace. Determinations were made with decreasing furnace temperature at $50 \mathrm{deg}$ intervals in the range 1100 to $50{ }^{\circ} \mathrm{C}$, as well as at $1063{ }^{\circ} \mathrm{C}, 630.5$, and $419.5{ }^{\circ} \mathrm{C}$. These measurements were followed by a second set of determinations made with increasing furnace temperature at $50 \mathrm{deg}$ in- tervals from 425 to $1075^{\circ} \mathrm{C}$ and the determinations at $400,419.5,630.5$, and $1063{ }^{\circ} \mathrm{C}$ were repeated. For these tests the measuring junctions of several 30-6 thermocouples, a platinum-10 percent rhodium versus platinum thermocouple and a platinum reference wire were welded into a common junction. The thermocouples and reference wire were placed in a closed end alumina protecting tube and inserted into the tube furnace until the common measuring junction was at the center of the furnace. The temperature of the furnace was regulated by the manual control of the power with an adjustable transformer. The emf of the platinum-rhodium thermoelement against the platinum reference wire and the emf of the platinum-10 percent rhodium versus platinum thermocouple were determined simultaneously by the two-potentiometer method. The two-potentiometer method is described in section 4.1 of NBS Circular 590 .

\section{b. Tests in Stirred Liquid Baths in Range 0 to $450{ }^{\circ} \mathrm{C}$}

Thermocouples A1, B3, and C2 were selected for testing in the stirred liquid baths in the range 0 to $450{ }^{\circ} \mathrm{C}$. For these tests the $\mathrm{Pt}-6.12$ percent Rh elements of the three thermocouples and a platinum reference wire were assembled in a four bore alumina insulating tube and the measuring junction of the wires welded together. The Pt-29.60 percent Rh elements and a platinum reference wire were assembled in the same manner. Each of the alumina insulating tubes was inserted into a closed end Pyrex protecting tube.

The assemblies were immersed in the stirred liquid bath along with a platinum resistance thermometer. The temperature of the bath was regulated by manually controlling the power input to the bath with an adjustable transformer. With the temperature of the bath held nearly constant the emfs of the Pt-6.12 percent $\mathrm{Rh}$ and $\mathrm{Pt}-29.60$ percent $\mathrm{Rh}$ wires against the platinum reference wires were measured. The measurements were preceded and followed by determinations of the bath temperature with the platinum resistance thermometer. In this manner, measurements were made at $25 \mathrm{deg}$ intervals from 25 to $450^{\circ} \mathrm{C}$. Four different stirred liquid baths were required for this purpose.

\section{c. Calibration of Thermocouples by Direct Comparison With Optical Pyrometer in Range 1050 to $1600{ }^{\circ} \mathrm{C}$ (Thermocouples Heated in SiC Tube Furnace)}

Thermocouples A1, A2, B2, B3, C1, C2, D1, and D2 were calibrated one at a time in the range 1050 to $1600{ }^{\circ} \mathrm{C}$ in the $\mathrm{SiC}$ tube furnace (see fig. 3). The thermocouple to be calibrated was inserted into the alumina protecting tube so that the measuring junction was in contact with the closed end of the tube. The temperature of the alumina "blackbody" was controlled near a desired calibration point by manually regulating the input power to the $\mathrm{SiC}$ tube with an adjustable transformer. An optical pyrometer was optically alined with the axis of the $1 / 8$ in. diam sight 
hole in the alumina "blackbody" and focused on the hole near the surface. Brightness matches were made with the optical pyrometer by two experienced observers. With the temperature of the "alumina blackbody" held nearly constant (changing less than a few tenths of a deg per minute), a set of four independent brightness matches was made with the optical pyrometer by each observer. For every brightness match the pyrometer lamp current was determined and the emf of the thermocouple was measured simultaneously. A group of such readings was taken at about $1063{ }^{\circ} \mathrm{C}$ and then at approximately $50 \mathrm{deg}$ intervals from 1050 to $1600{ }^{\circ} \mathrm{C}$ for each of the thermocouples. Some of the thermocouples were calibrated with increasing temperature, some with decreasing temperature, and others with both increasing and decreasing temperature. Approximately 6 to $8 \mathrm{hr}$ was required to complete the calibration of each thermocouple in the range 1050 to $1600{ }^{\circ} \mathrm{C}$.

Several problems were encountered with the measurements in the $\mathrm{SiC}$ tube furnace at the higher temperatures. Occasionally, the $\mathrm{SiC}$ tube would develop a "smoking condition" at the higher temperatures (usually above $1500{ }^{\circ} \mathrm{C}$ ). When this occurred the furnace was cooled and the smoke was blown from the inside of the tube before attempting to make any further measurements with the optical pyrometer. Even so, a slight haze was sometimes noticeable inside the tube during the measurements. The effect of the haze on the optical pyrometer measurements was not known.

Also at temperatures above about $1500{ }^{\circ} \mathrm{C}$ a problem was experienced with the emf measurements which was attributed to electrical leakage between the thermocouple wires and the $\mathrm{SiC}$ heating element, through the alumina insulating parts and "blackbody." When the furnace power was turned off (briefly) at temperatures above about $1500{ }^{\circ} \mathrm{C}$ a difference in the emf of the thermocouple was usually observed. The magnitude and direction of the change in emf was unpredictable and would vary from thermocouple to thermocouple and from run to run. However, the change in emf was never observed to be more than $6 \mu \mathrm{V}$.

For measurements above $1500{ }^{\circ} \mathrm{C}$ the change in emf was determined after each set of readings and the appropriate correction was applied to the measured emfs. By this procedure it is estimated that the uncertainty in the emf measurements, because of the electrical leakage, was reduced to about $1 \mu \mathrm{V}$ or less.

Finally, a chemical reaction apparently occurred between the alumina "blackbody" and the SiC heating element at the higher temperatures. The electrical properties or characteristics of the $\mathrm{SiC}$ tube changed in the central region where the $\mathrm{SiC}$ tube and the alumina were in contact, and a "hot spot" developed in the tube. Consequently, the temperature distribution over the alumina "blackbody" became progressively less uniform and some additional uncertainty was introduced in the measurements. However, the temperature gradients were not severe and the error introduced by the nonuniform temperature probably did not exceed more than 1 or $2 \mathrm{deg}$ at $1600{ }^{\circ} \mathrm{C}$.

\section{d. Calibration of Thermoelements by Comparison With Platinum Reference Wires in Range 1063 to $1500{ }^{\circ} \mathrm{C}$}

The emfs of the thermoelements of thermocouples $\mathrm{A} 1, \mathrm{~B} 2, \mathrm{C} 1$, and D2 were determined against platinum reference wires at $1063{ }^{\circ} \mathrm{C}$ and then at $50 \mathrm{deg}$ intervals with increasing temperature from 1100 to $1500{ }^{\circ} \mathrm{C}$. The tests were made in the $\mathrm{SiC}$ tube furnace. For these tests another $\mathrm{SiC}$ heating tube was assembled in the furnace and a large diameter, closed end, alumina protecting tube (18 in. long with an inside diameter of $3 / 4$ in.) was positioned inside the $\mathrm{SiC}$ heating tube. During the tests the thermocouples were located inside the alumina protecting tube and the tube was supported near the open end so as not to be in contact with the $\mathrm{SiC}$ heating tube. The test procedures were similar to those described in section 4.la except that the temperature was determined with a 30-6 thermocouple (thermocouple B3), instead of a $\mathrm{Pt}-10$ percent $\mathrm{Rh}$ versus $\mathrm{Pt}$ thermocouple.

e. Calibration of Thermocouples by Comparison With Pt-10 Percent $\mathrm{Rh}$ versus $\mathrm{P}$ t Thermocouple in Range 1063 to $1450{ }^{\circ} \mathrm{C}$

Thermocouples A1, A2, B2, B3, C1, C2, D1, and D2 were tested by comparing them directly with a $\mathrm{Pt}-10$ percent $\mathrm{Rh}$ versus $\mathrm{Pt}$ thermocouple in the 1063 to $1450{ }^{\circ} \mathrm{C}$ range. The thermocouples were heated in the $\mathrm{SiC}$ tube furnace. The emf of each 30-6 thermocouple was determined at $1063{ }^{\circ} \mathrm{C}$ and then at $50 \mathrm{deg}$ intervals with increasing temperature from 1100 to $1450{ }^{\circ} \mathrm{C}$ by using the two-potentiometer method.

\section{f. Calibration of Thermocouples by Direct Comparison With Optical Pyrometer in Range 1063 to $1790{ }^{\circ} \mathrm{C}$ (Thermocouples Heated in Pt-Rh Wire Wound Tube Furnace)}

Thermocouples A2, A3, B1, B3, C2, C3, D1, and D2 were calibrated by comparison with an optical pyrometer and the thermocouples were heated in the $\mathrm{Pt}-\mathrm{Rh}$ wire wound tube furnace shown in figure 4 . During these tests the $\mathrm{Pt}-\mathrm{Rh}$ shield in the furnace was electrically grounded, and no difficulty was experienced with the emf measurements due to electrical leakage between the thermocouples and heater windings. The temperature control of the furnace was considerably more difficult than for the $\mathrm{SiC}$ tube furnace and rather tedious adjustments of the power to the various heater windings were required. The temperature profile in the region of the alumina "blackbody" was checked frequently with the 30-6 thermocouple being tested. The temperature was controlled and the temperature gradients minimized by manual regulation of the power to the various heater windings with variable transformers.

The calibration procedures for the thermocouples were similar to the procedures described in section 4.1c. Sets of brightness matches were taken by two different observers with the optical pyrometer and the emfs of the thermocouples were determined at about 
$1063{ }^{\circ} \mathrm{C}$ and then at approximately $50 \mathrm{deg}$ intervals from 1100 to $1600{ }^{\circ} \mathrm{C}$.

After completing the tests in the 1063 to $1600{ }^{\circ} \mathrm{C}$ range, each of the thermocouples was reassembled in double bore beryllium oxide insulating tube. The thermocouples were then calibrated at about 1600, 1650,1700 , and $1750{ }^{\circ} \mathrm{C}$. Three of the thermocouples (A3, B1, C3) were also calibrated at about $1790{ }^{\circ} \mathrm{C}$.

The calibrations described in this section were made with increasing furnace temperature. The thermocouples were removed from the furnace after taking the measurements at each calibration point and then reinserted after the temperature of the furnace was increased to the next calibration point. In general, the time required for checking the temperature gradients in the central portion of the furnace, for allowing the temperature of the furnace to stabilize, and for the two observers to take a set of observations with the optical pyrometer seldom exceeded $20 \mathrm{~min}$ at a calibration point for each thermocouple.

Several of the thermocouples were recalibrated at $1063{ }^{\circ} \mathrm{C}$ by the procedures described in section 4.1 a following completion of the test to $1600{ }^{\circ} \mathrm{C}$ and then again following the tests to 1750 and $1790^{\circ} \mathrm{C}$.

\subsection{Tests of Platinum-Rhodium Wires With Various Percentages of Rhodium}

The platinum-rhodium wires were prepared for test by annealing them electrically in air for $1 \mathrm{hr}$ at about $1450{ }^{\circ} \mathrm{C}$. The wires were then assembled in alumina insulating tubes. The emfs of the platinumrhodium wires with rhodium percentages of 5.90, $5.95,6.00,6.05$, and 6.10 were determined against a Pt-6.12 percent $\mathrm{Rh}$ wire (negative leg of thermocouple B2). Similarly, the emf of the platinumrhodium wires with rhodium percentages of 29.50, $29.75,30.00$, and 30.25 were determined against a Pt-29.60 percent $\mathrm{Rh}$ wire (positive leg of thermocouple B2). In the first set of measurements the measuring junctions of the various $\mathrm{Pt}-6$ percent $\mathrm{Rh}$ wires and a $\mathrm{Pt}-10$ percent $\mathrm{Rh}$ versus $\mathrm{Pt}$ thermocouple were welded into a common junction and the wires and the thermocouple were inserted into the nickelchromium tube furnace. The emf of the Pt-Rh wires against the $\mathrm{Pt}-6.12$ percent $\mathrm{Rh}$ wire and the emf of the $\mathrm{Pt}-10$ percent $\mathrm{Rh}$ versus $\mathrm{Pt}$ thermocouple were measured simultaneously by the two-potentiometer method. Measurements were made at $100 \mathrm{deg}$ intervals with decreasing furnace temperature from 1100 to $100{ }^{\circ} \mathrm{C}$. The $\mathrm{Pt}-10$ percent $\mathrm{Rh}$ versus thermocouple was then replaced with a $30-6$ thermocouple (thermocouple B3) and measurements were made by the same method at $100 \mathrm{deg}$ intervals from 1100 to $1600{ }^{\circ} \mathrm{C}$ in the $\mathrm{SiC}$ tube furnace. Measurements were also made at $100 \mathrm{deg}$ intervals with the various $\mathrm{Pt}-30$ percent $\mathrm{Rh}$ wires from 0 to $1600{ }^{\circ} \mathrm{C}$ by the same procedure.

\subsection{Tests of Thermocouples in Table 4}

Each of the thermocouples in table 4 was electrically annealed in air for $1 \mathrm{hr}$ at about $1450{ }^{\circ} \mathrm{C}$ and then assembled in a double bore alumina insulating tube before testing. The thermocouples were calibrated by direct comparison with calibrated thermocouples using the two-potentiometer method. The thermocouples were heated in the nickel-chromium tube furnace and a $\mathrm{Pt}-10$ percent $\mathrm{Rh}$ versus $\mathrm{Pt}$ thermocouple was used to determine the temperature in the range up to $1063{ }^{\circ} \mathrm{C}$. Above $1063{ }^{\circ} \mathrm{C}$ the thermocouples were heated in the $\mathrm{SiC}$ tube furnace and one of the 30-6 thermocouples in table 2 was used to determine the temperature.

\section{Computations}

From the results of the tests described in sections $4.1 \mathrm{a}$ and $4.1 \mathrm{~b}$ corresponding values of temperature and emf were calculated at $25 \mathrm{deg} C$ intervals from 0 to $1050{ }^{\circ} \mathrm{C}$ and at $419.5,630.5$, and $1063{ }^{\circ} \mathrm{C}$ for each thermocouple. Similarly, from the tests described in section 4.1f corresponding values of temperature and emf were calculated at $1063{ }^{\circ} \mathrm{C}$ and at $50 \mathrm{deg}$ intervals from 1100 to $1750{ }^{\circ} \mathrm{C}$ for each thermocouple. In the latter calculations the four readings of each observer with the optical pyrometer were averaged to obtain a single emf value for each thermocouple at about $1063{ }^{\circ} \mathrm{C}$ and at about $50 \mathrm{deg}$ intervals from 1100 to $1750{ }^{\circ} \mathrm{C}$. These values were adjusted to obtain values at exactly $1063{ }^{\circ} \mathrm{C}$ and at the nearest integral multiples of $50{ }^{\circ} \mathrm{C}$ and then the values of each observer for each thermocouple were averaged to obtain a single value of emf at each temperature. Since the measured values were nearly always within the equivalent of $5 \mathrm{deg}$ of integral multiples of $50 \mathrm{deg}$, the adjustment could be made without introducing any significant error by using an approximate value for the thermoelectric power $\left(\frac{d E}{d T}\right)$ of the thermocouple at each
temperature.

With the use of an IBM 7094 digital computer cubic equations were fitted by the method of least squares to the sets of emf and temperature values obtained for each thermocouple. One of the cubic equations was selected arbitrarily to serve as a rough "standard curve" with which to compare all the individual thermocouples. The deviations of the measured emf values for each thermocouple from the "standard curve" were plotted graphically and an "average deviation curve" was drawn by visually estimating the best fit. From the "average deviation curve" corresponding values of emf and temperature were calculated at $25 \mathrm{deg} \mathrm{C}$ intervals from 0 to $1825^{\circ} \mathrm{C}$.

This set of values was taken as the "principal points" upon which the reference table would be based. Several methods were considered for constructing an expanded set of temperature and emf values (the reference table) at $1 \mathrm{deg}$ intervals from the "principal points." Hand calculation of the reference table using graphical interpolation and smoothing was a possible, but tedious solution. This method was not seriously considered, since a primary requirement was to adopt a method for representing the table that could be 
easily adapted to computer use. The method of second degree Lagrange interpolation applied to the "principal points" was given serious consideration, but was rejected in favor of using a single equation or several smoothly jointing equations.

The use of equations to represent the table instead of the Lagrange interpolation scheme seemed preferable for two reasons. First, equations require less storage space in the computer and their use is preferred by most people. Second, a set of "key values" can be generated from the equations and then the Lagrange interpolation scheme can be used for repsenting the table, if it is preferred. From preliminary curve fitting it was determined that a single polynomial equation of fairly low degree would not give an adequate representation of the temperature-emf relationship. Consequently, with the use of the IBM 7094 computer a series of polynomial equations was fitted to the "principal points" by the method of least squares. By trial, it was found that a good fit was obtained with a series of three quartic equations of the form: $E=a+b t+c t^{2}+d t^{3}+e t^{4}$, where $E$ is the emf in absolute millivolts and $t$ is the temperature in degrees C (Int. 1948). The ranges of the three equations are 0 to $800{ }^{\circ} \mathrm{C}, 800$ to $1175^{\circ} \mathrm{C}$, and 1175 to 1820 ${ }^{\circ} \mathrm{C}$, and the coefficients of the equations were computed such that, at the crossover points of 800 and $1175{ }^{\circ} \mathrm{C}$ the emfs from each of the joining equations were equal and also the first derivatives $\left(\frac{d E}{d t}\right)$ of emf with respect to temperature were equal. The largest or maximum deviation of the equations from the "principal points" was $0.56 \mu \mathrm{V}$ below $1175^{\circ} \mathrm{C}$ and $0.88 \mu \mathrm{V}$ in the region above $1175{ }^{\circ} \mathrm{C}$, while the standard deviations for the fit of the three equations to the "principal points" were $0.31,0.36$, and $0.40 \mu \mathrm{V}$ for the ranges 0 to 800 , 800 to 1175 , and 1175 to 1825 , respectively.

By substituting for $t$ in the equations the relationship $5 / 9\left(t_{f}-32\right)$, where $t_{f}$ is the temperature in degrees Fahrenheit, a set of three equations was calculated with the temperature expressed in degrees Fahrenheit. The coefficients and temperature ranges for the two sets of equations are given in table 6 .

A method of successive approximations was developed for obtaining values of temperature from the equations at exact integral values of the emf. Sufficient accuracy was obtained with this inversion method by merely continuing the approximation until the required number of significant figures was achieved.

Using the results of the tests described in sections $4.1 \mathrm{a}, 4.1 \mathrm{~b}$, and $4.1 \mathrm{~d}$ and curve fitting techniques similar to those described previously, smoothed emf values for Pt-6.12 percent $\mathrm{Rh}$ versus $\mathrm{Pt}-27$ were determined at $50{ }^{\circ} \mathrm{C}$ intervals from 0 to $1500{ }^{\circ} \mathrm{C}$. A set of emf values for $\mathrm{Pt}-29.60$ percent $\mathrm{Rh}$ versus $\mathrm{Pt}-27$ was then obtained by adding the set of emf values for $\mathrm{Pt}$ 6.12 percent $\mathrm{Rh}$ versus $\mathrm{Pt}-27$ to the temperature-emf values given by the reference table for the thermocouple.

TABLE 6. Coefficients and temperature ranges of equations for 30-6 thermocouple reference table Equations of the form $\left(E=a+b t+c t^{2}+d t^{3}+e t^{4}\right)^{*}$ where $\mathrm{E}$ is given in abs. millivolts.

\begin{tabular}{c|c|c|c|c|c|c}
\cline { 2 - 6 } & \multicolumn{5}{|c}{} & \multicolumn{3}{c}{${ }^{*} t$ expressed in degrees Fahrenheit } \\
\hline Coefficients & Ranges & $0-800{ }^{\circ} \mathrm{C}$ & $800-1175^{\circ} \mathrm{C}$ & $1175-1820{ }^{\circ} \mathrm{C}$ & $32-1472{ }^{\circ} \mathrm{F}$ & $1472-2147^{\circ} \mathrm{F}$ \\
a & 0 & -1.5120133 & 6.5238699 & $0.60419 \times 10^{-2}$ & -1.6253233 \\
$\mathrm{~b}$ & $-2.37021 \times 10^{-4}$ & $6.286779 \times 10^{-3}$ & $-0.17621535 \times 10^{-1}$ & $-.24594442 \times 10^{-3}$ & $0.35904493 \times 10^{-2}$ & $-0.10239859 \times 10^{-1}$ \\
$\mathrm{c}$ & $0.5767866 \times 10^{-5}$ & $-0.4764704 \times 10^{-5}$ & $.2258695 \times 10^{-4}$ & $.17906004 \times 10^{-5}$ & $-.15858965 \times 10^{-5}$ & $.70950713 \times 10^{-5}$ \\
$\mathrm{~d}$ & $-.6332156 \times 10^{-9}$ & $.6930475 \times 10^{-8}$ & $-.7488765 \times 10^{-8}$ & $-.10798282 \times 10^{-9}$ & $.12139161 \times 10^{-8}$ & $-.12948876 \times 10^{-8}$ \\
$\mathrm{e}$ & $-.48653 \times 10^{-13}$ & $-.209649 \times 10^{-11}$ & $.8862174 \times 10^{-12}$ & $-.46346781 \times 10^{-14}$ & $-.19971135 \times 10^{-12}$ & $.84420950 \times 10^{-13}$ \\
\hline
\end{tabular}

\section{Results}

\subsection{Results of Tests on Thermocouple Materials Used in the Preparation of the Reference Table}

Reference tables (tables $1 \mathrm{~A}$ and $3 \mathrm{~A}$ ) for the 30-6 thermocouple for a reference junction temperature of $0{ }^{\circ} \mathrm{C}\left(32{ }^{\circ} \mathrm{F}\right)$ were generated from the polynomial equations (see table 6 for coefficients of the polynomial equations). In reference table $1 \mathrm{~A}$ values of emf are given in absolute millivolts at $1 \mathrm{deg} C$ intervals for the range 0 to $1820{ }^{\circ} \mathrm{C}$. Similarly, table $3 \mathrm{~A}$ gives values of emf at 1 degree $\mathrm{F}$ intervals for the range 32 to $3308{ }^{\circ} \mathrm{F}$. Reference tables $2 \mathrm{~A}$ and $4 \mathrm{~A}$ are an inversion of tables $1 \mathrm{~A}$ and $3 \mathrm{~A}$, respectively, and were developed by the computer technique described in the computation section. Table $2 \mathrm{~A}$ gives values of the temperature in degrees $\mathrm{C}$ at $0.01 \mathrm{mV}$ intervals, while table $4 \mathrm{~A}$ gives values of temperature in degrees $\mathrm{F}$ at $0.01 \mathrm{mV}$ intervals.

The thermoelectric power $\left(\frac{d E}{d t}\right)$ of the thermocouple was calculated from the polynomial equations and is plotted against temperature in figure 5. The thermo- 


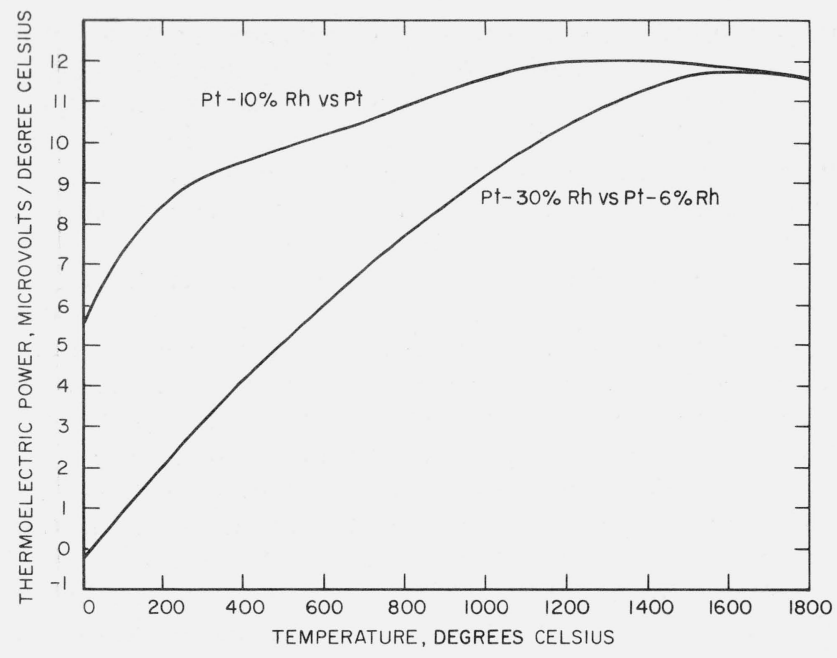

electric power ${ }^{5}$ of the more common $\mathrm{Pt}-10$ percent $\mathrm{Rh}$ versus $\mathrm{Pt}$ thermocouple is also shown in figure 5 for purposes of comparison. The difference between the average calibration of the thermocouples from each manufacturer and the temperature-emf relationship given by the reference table are plotted in figure 6 for the range 0 to $1750{ }^{\circ} \mathrm{C}$. The values shown in the figure in the range 0 to $1063{ }^{\circ} \mathrm{C}$ were calculated from the results of the tests described in sections $4.1 \mathrm{a}$ and $4.1 \mathrm{~b}$, and the values shown in the range 1063 to 1750 ${ }^{\circ} \mathrm{C}$ were calculated from tests described in section 4.1f. Since the elements of the thermocouples from each manufacturer were adjacent elements from the same wire lots, there was very little difference between the temperature-emf relationships of the thermocouples from the same manufacturer. For example, at $1063{ }^{\circ} \mathrm{C}$ the emf of each individual thermocouple from the same manufacturer (as determined in the

FigURE 5. Thermoelectric power $\left(\frac{\mathrm{dE}}{\mathrm{dt}}\right)$ of Pt-10 percent Rh versus $P t$ and Pt-30 percent Rh versus Pt-6 percent Rh thermocouples. ${ }^{5}$ Calculated from the $\mathrm{Pt}-10$ percent $\mathrm{Rh}$ versus $\mathrm{Pt}$ thermocouple reference table given in
NBS Circ. 561.

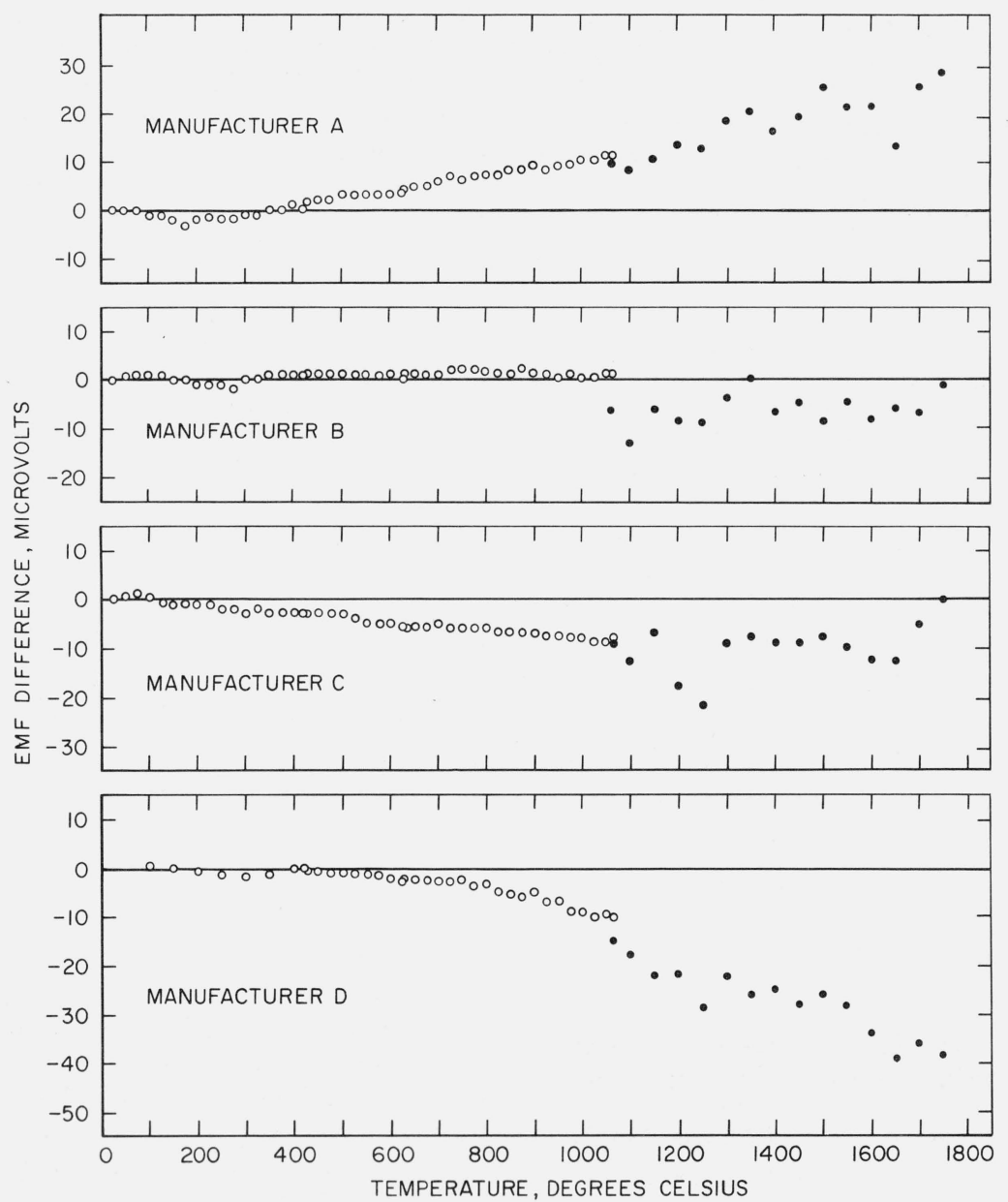

FIGURE 6. Emf difference between average calibration of thermocouples from each manufacturer (see table 2) and the reference table (table $1 A$ ).

Emf difference equals emf of thermocouple minus emf of reference table. Open symbols indicate temperature determined with standard thermocouples and resistance thermometers as described in sections $4.1 \mathrm{a}$ and $4.1 \mathrm{~b}$. respectively. Closed symbols indicate temperature determined with optical pyrometer as described in section 4.lf. 
test described in section 4.1a), in no case differed by more than about $1 \mu \mathrm{V}$ from the average emf of all the thermocouples from the manufacturer. For this reason, the individual calibrations of each of the thermocouples in table 2 are not shown but only the average calibration of the thermocouples of each manufacturer.

In table 7 the emf of the platinum- 6.12 percent rhodium and the platinum 29.60 percent rhodium elements versus $\mathrm{Pt}-27$ are given at $50 \mathrm{deg} \mathrm{C}$ intervals for the range 0 to $1500{ }^{\circ} \mathrm{C}$. The difference between the temperature-emf values for the Pt-6.12 percent $\mathrm{Rh}$ elements of each manufacturer against $\mathrm{Pt}-27$ and the temperature-emf values given in table 7 for the Pt-6.12 percent Rh versus $\mathrm{Pt}-27$ are plotted in figure 7. Similarly, the difference between the temperature-emf values determined for the Pt-29.60 percent Rh elements against Pt-27 and the temperature-emf values given in table 7 for $\mathrm{Pt}-29.60$ percent $\mathrm{Rh}$ versus $\mathrm{Pt}-27$ are plotted in figure 8 .

TABLE 7. Emf of platinum-6.12 percent rhodium and platinum29.60 percent rhodium versus $P t-27$

\begin{tabular}{|c|c|c|}
\hline \multirow{2}{*}{$\begin{array}{l}\text { Temperature } \\
\text { degrees C } \\
\text { (Int. 1948) }\end{array}$} & \multicolumn{2}{|c|}{ Emf (abs. mV) } \\
\hline & $\mathrm{Pt}-6.12 \% \mathrm{Rh}$ & Pt $29.60 \%$ Rh \\
\hline 0 & 0.000 & 0.000 \\
\hline 50 & .276 & .278 \\
\hline 100 & .586 & .619 \\
\hline 150 & .920 & 1.012 \\
\hline 200 & 1.272 & 1.450 \\
\hline 250 & 1.636 & 1.927 \\
\hline 300 & 2.007 & 2.438 \\
\hline 350 & 2.384 & 2.980 \\
\hline 400 & 2.765 & 3.551 \\
\hline 450 & 3.148 & 4.150 \\
\hline 500 & 3.534 & 4.775 \\
\hline 550 & 3.922 & 5.427 \\
\hline 600 & 4.313 & 6.104 \\
\hline 650 & 4.708 & 6.808 \\
\hline 700 & 5.106 & 7.537 \\
\hline 750 & 5.508 & 8.292 \\
\hline 800 & 5.914 & 9.072 \\
\hline 850 & 6.323 & 9.874 \\
\hline 900 & 6.737 & 10.700 \\
\hline 950 & 7.154 & 11.549 \\
\hline 1000 & 7.576 & 12.420 \\
\hline 1050 & 8.003 & 13.314 \\
\hline 1100 & 8.432 & 14.225 \\
\hline 1150 & 8.863 & 15.153 \\
\hline 1200 & 9.296 & 16.096 \\
\hline 1250 & 9.732 & 17.058 \\
\hline 1300 & 10.169 & 18.035 \\
\hline 1350 & 10.608 & 19.026 \\
\hline 1400 & 11.046 & 20.025 \\
\hline 1450 & 11.480 & 21.029 \\
\hline 1500 & 11.911 & 22.035 \\
\hline
\end{tabular}

\subsection{Results of Tests on Platinum-Rhodium Wires With Various Percentages of Rhodium}

The emfs of the platinum-rhodium wires with compositions of Pt -5.90 percent Rh, Pt-5.95 percent Rh, Pt-6.00 percent Rh, Pt-6.05 percent Rh, $\mathrm{Pt}-6.10$ percent $\mathrm{Rh}$ are shown versus a $\mathrm{Pt}-6.12$ percent $\mathrm{Rh}$ wire (negative leg of thermocouple B2) in figure 9. In figure 10

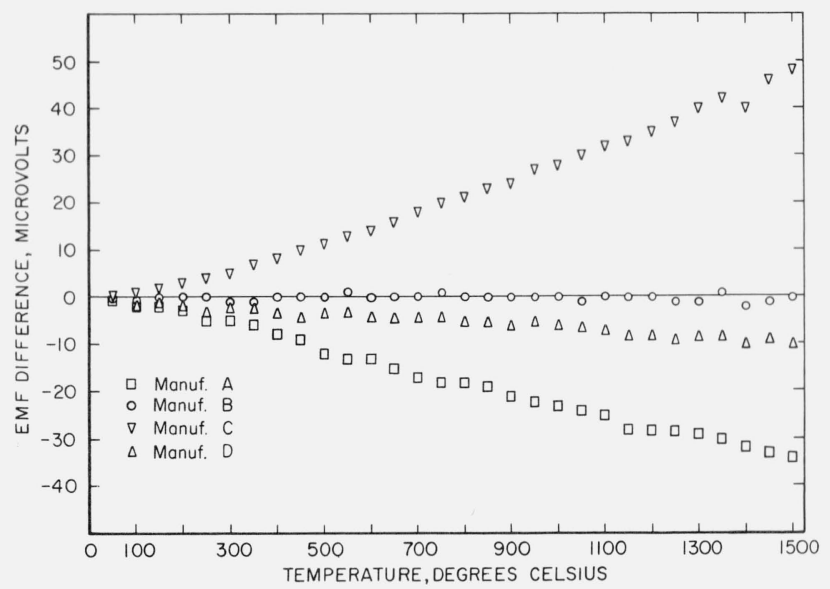

Figure 7. Emf difference between Pt-6.12 percent Rh elements of each manufacturer and corresponding values in table 7 for emf of Pt-6.12 percent Rh versus Pt-27.

Emf difference equals emf of element minus emf in table 7 at temperature indicated. Values shown determined in tests described in sections 4.1a. 4.1b. and 4.1d.

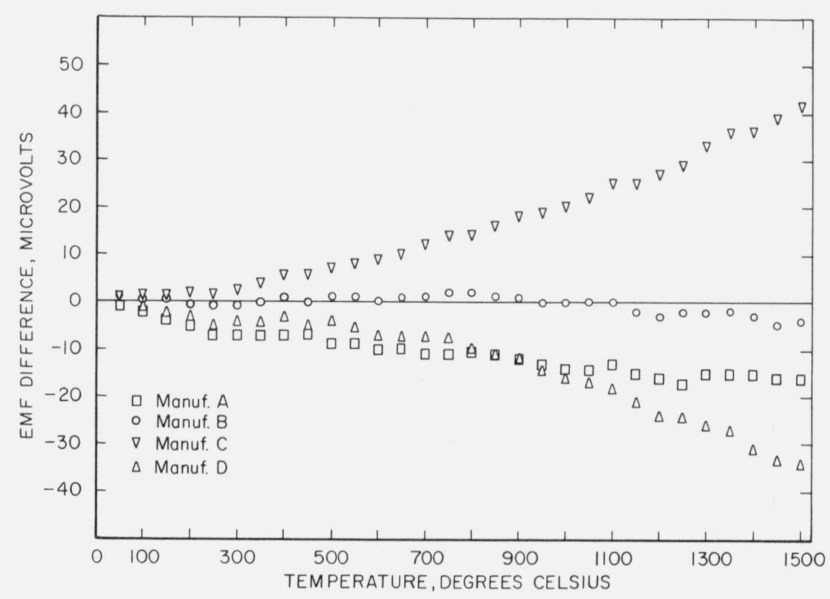

Figure 8. Emf difference between Pt-29.60 percent Rh elements of each manufacturer and corresponding values in table 7 for emf of $P t-29.60$ percent $R h$ versus $P t-27$.

Emf difference equals emf of element minus emf in table 7 at temperature indicated. Values shown determined in tests described in sections 4.1a, 4.1b. and 4.1d.

the emfs of the platinum-rhodium wires with compositions of Pt-29.50 percent Rh, Pt-29.75 percent Rh, Pt-30.00 percent Rh, Pt-30.25 percent Rh are shown versus a $\mathrm{Pt}-29.60$ percent $\mathrm{Rh}$ wire (positive leg of thermocouple B2) for the 0 to $1600{ }^{\circ} \mathrm{C}$ range.

\subsection{Results of Testing for Other 30-6 Thermocouples}

The deviations (expressed in microvolts) of the various thermocouples in table 4 from the reference table are shown in figure 11. 

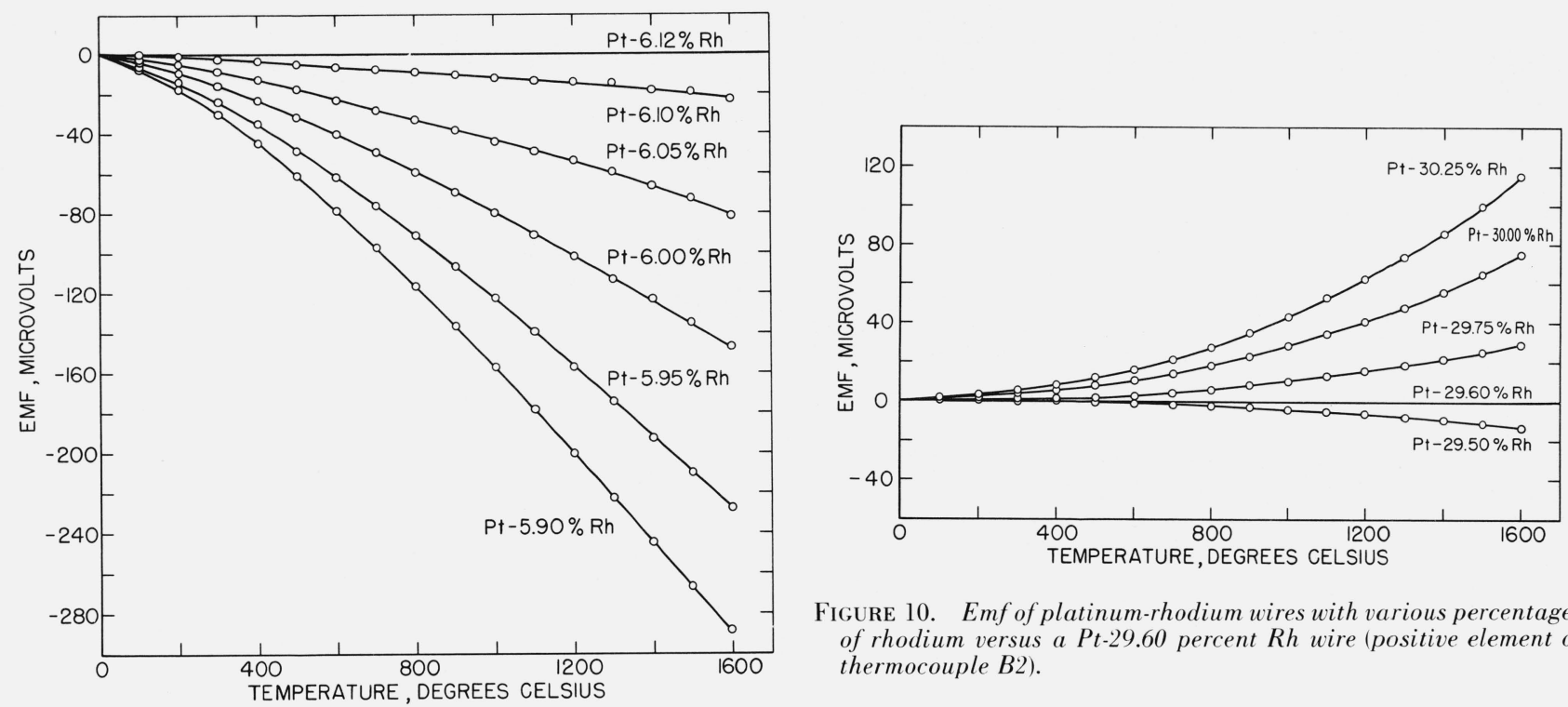

FigURE 10. Emf of platinum-rhodium wires with various percentages of rhodium versus a $\mathrm{Pt}-29.60$ percent $R h$ wire (positive element of thermocouple B2).

FIGURE 9. Emf of platinum-rhodium wires with various percentages of rhodium versus a Pt-6.12 percent Rh wire (negative element of thermocouple B2).

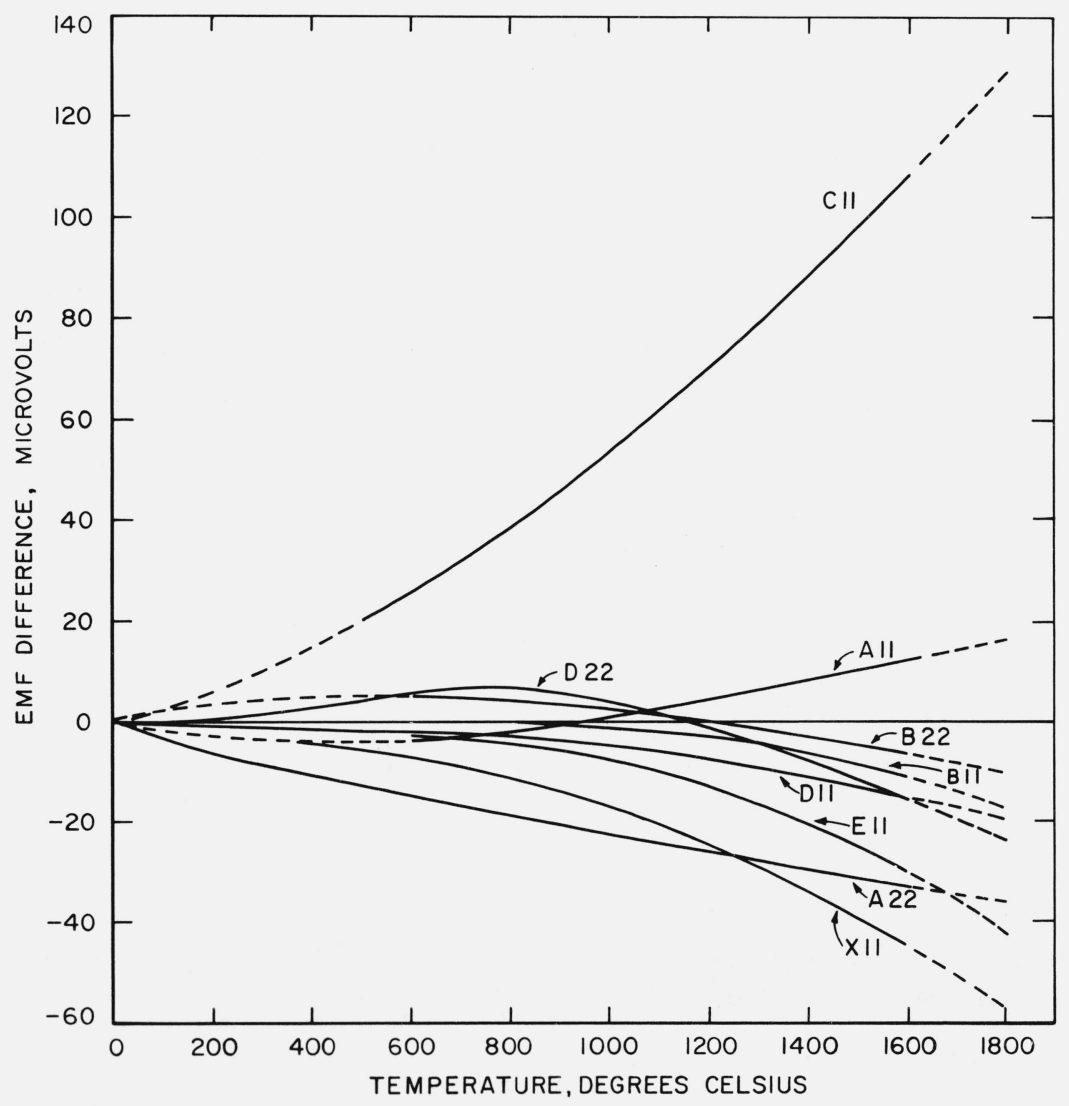

FIGURE 11. Deviation of thermocouples in table 4 from reference table.

Emf difference equals emf of thermocouple minus emf of reference table. Solid portion of curves indicate range of calibration data and dashed portions are extrapolated. 


\section{Discussion}

As shown in figure 6 the differences between the average calibrations of the thermocouples from the different manufacturers and the temperature-emf relationship given by the reference table are quite small. The largest deviation for thermocouples from an American manufacturer occurs at $1750{ }^{\circ} \mathrm{C}$ for the thermocouples from manufacturer $\mathrm{A}$ and is only about $28 \mu \mathrm{V}$ (about $2.4^{\circ} \mathrm{C}$ ). The differences between the temperature-emf relationships of the individual thermoelements of the thermocouples are somewhat larger than the difference between the temperature-emf relationships of the thermocouples themselves, as shown in figures 7 and 8 . The spread between the temperatureemf relationships of the $\mathrm{Pt}-6.12$ percent $\mathrm{Rh}$ thermoelements (fig. 7) is about the same as for the Pt-29.60 percent $\mathrm{Rh}$ thermoelements (fig. 8). The maximum spreads occur at the highest temperature measured, $1500{ }^{\circ} \mathrm{C}$, and are about $80 \mu \mathrm{V}$ and $75 \mu \mathrm{V}$ for the Pt-6.12 percent $\mathrm{Rh}$ and $\mathrm{Pt}-29.60$ percent $\mathrm{Rh}$ thermoelements, respectively.

It is interesting to note that the temperature-emf relationships of thermocouples from different manufacturers may agree quite closely, even though the temperature-emf relationship for the corresponding thermoelements of the thermocouples differ considerably. This is the case for the thermocouples from manufacturers B and C. It is also interesting that the spread between the temperature-emf relationships of the $\mathrm{Pt}-29.60$ percent $\mathrm{Rh}$ elements from different manufacturers is about as large as the spread between the temperature-emf relationships of the $\mathrm{Pt}-6.12$ percent Rh elements. This is a little surprising, since a small variation in rhodium content has a more pronounced effect on the temperature-emf relationship of the dilute alloy (Pt-6.12\% Rh).

The differences between the temperature-emf relationships of the various thermocouples and platinumrhodium thermoelements are attributed to slight variations in the chemical compositions of the wires. In general, two platinum-rhodium wires of the same nominal type will differ slightly in chemical composition because of a variation in purity combined with a slight variation in the rhodium content.

It can be seen from the results of the spectrochemical analyses (table 3 ) that some significant differences in the purity of the platinum-rhodium thermoelements from the various manufacturers do exist. Appreciable amounts of $\mathrm{Fe}, \mathrm{Ir}, \mathrm{Au}, \mathrm{Pd}, \mathrm{Si}$, and $\mathrm{Al}$ were detected in some of the platinum-rhodium wires as well as small traces of $\mathrm{Ca}, \mathrm{Mg}, \mathrm{B}$, and $\mathrm{Cu}$. A fairly large amount of aluminum was detected in the $\mathrm{Pt}-29.60$ percent $\mathrm{Rh}$ wire submitted by manufacturer $\mathrm{B}$, while none was detected in any of the other wires. However, the aluminum is probably present in oxide form and would be expected to have little or no effect on the thermoelectric characteristics of the wire. Of more importance is that the concentrations of $\mathrm{Fe}, \mathrm{Ir}, \mathrm{Au}$, and $\mathrm{Pd}$ detected in the wires of manufacturers $\mathrm{A}$ and $\mathrm{D}$ were, in general, somewhat higher than the concentrations detected in the wires of manufacturers B and C. Another interesting point is that the wires of manufacturer D (Degussa) contained less $\mathrm{Si}$ than the wires submitted by the American manufacturers (A, B, and C). Also, the results of the analysis on the reference grade platinum wire shows that commercially available thermocouple platinum is considerably more pure than platinumrhodium alloys. Consequently, the relative impurity of the platinum-rhodium alloys is attributed for the most part to impurities in the rhodium constituent.

The curves in figures 9 and 10 show the effect on the temperature-emf relationship of $\mathrm{Pt}-6$ percent $\mathrm{Rh}$ and Pt-30 percent Rh thermoelements, respectively, caused by small variations in rhodium content. The differences between the curves are assumed to a first approximation to be entirely due to differences in rhodium. This assumption seems reasonable since the wires in each group were prepared by the same manufacturer from the same batch of platinum and rhodium. For example, the $\mathrm{Pt}-30.25$ percent $\mathrm{Rh}$ wire should contain the same inpurities as the Pt-29.50 percent Rh wire and the concentrations would be expected to differ by a factor of only about $\frac{30.25}{29.50}$ (ratio of the rhodium percentages). It can be calculated from the curves that a 0.1 percent change in the rhodium content of a Pt-29.60 percent $\mathrm{Rh}$ wire will produce a corresponding change in the emf of about $15 \mu \mathrm{V}$ at $1500{ }^{\circ} \mathrm{C}$, while a change in the rhodium content of only about 0.01 percent will produce the same change in the emf of a Pt-6.12 percent $\mathrm{Rh}$ wire.

Efforts to determine the percentage of rhodium in the Pt-Rh elements from the different manufacturers to a few hundredths of a percent by chemical analysis were unsuccessful. Consequently, it is difficult, if not impossible, to establish whether the differences between the temperature-emf relationships of the thermoelements from different manufacturers are caused primarily by variation in purity or by variation in rhodium content. However, the variations of the impurities and their concentrations between thermoelements undoubtedly are large enough to be responsible for at least part of the differences. Also, slight variations in the rhodium content of thermoelements from different manufacturers are unavoidable and these variations combined with the variations in purity can easily account for the differences in emf shown in figures 7 and 8.

It has been suggested that slight differences in the alloying percentage of platinum and rhodium, and variations in purity can explain differences in the temperature-emf relationships of thermoelements and thermocouples from different manufacturers. For these same reasons differences between the temperature-emf relationships of thermocouples from the same manufacturer, but from different lots, will also occur. Comparison of the deviation curves in figure 11 with the deviation curves in figure 6 , shows that the differences between the temperature-emf relationships of thermocouples from the same manufacturer do exist and can be rather large. For example, the difference between the average calibration of thermocouples C1, C2, and 
C3 (shown by curve for manufacturer C in fig. 6) and the calibration of thermocouple C11 (see fig. 11) is about $130 \mu \mathrm{V}$ at $1600{ }^{\circ} \mathrm{C}$. The difference is larger than the differences between the temperature-emf relationships of any of the other thermocouples and probably represents a rather extreme case. For thermocouples tested from the other manufacturers differences in emf at $1600{ }^{\circ} \mathrm{C}$ ranging from a few microvolts up to about $60 \mu \mathrm{V}$ were typical for lot to lot differences.

If thermocouple C11 is disregarded, the variations among the temperature-emf relationships of all the other thermocouples in tables 2 and 4 are surprisingly small considering that five different manufacturers and about 12 different lots of wire are represented. The maximum difference between the temperature-emf relationships of the various thermocouples at $1600^{\circ} \mathrm{C}$ is about $70 \mu \mathrm{V}$ (about $6 \mathrm{deg} \mathrm{C}$ ), and the largest deviation of any thermocouple from the reference table is only about $45 \mu \mathrm{V}$ (about $3.8 \operatorname{deg} \mathrm{C}$ ). Consequently, it is estimated that nearly all the $30-6$ thermocouples produced by manufacturers in this country will have temperature-emf relationships that agree with the temperature-emf relationship given by the reference table to within the equivalent of \pm 0.5 percent of the temperature in the range 500 to $1800{ }^{\circ} \mathrm{C}$ and to within $\pm 15 \mu \mathrm{V}$ for temperatures below $500^{\circ} \mathrm{C}$.

These values do not represent a standard manufacturing tolerance for the 30-6 thermocouple, nor are they a recommendation for one. The values are merely estimates, based upon the calibrations of a rather small sampling of thermocouples which have been tested at NBS. The values are intended to serve as a guide for prospective users of the thermocouple, since no standard manufacturing tolerances exist for the thermocouple at present. If the 30-6 thermocouple comes into common use in this country, technical societies and manufacturers will most likely agree upon and adopt standard manufacturing tolerances.

The difference between the Degussa reference curves (old and new) and the reference table presented with this paper are shown in figure 12. It can be seen that the differences between the new Degussa reference curve, established by Obrowski and Prinz [7], and the temperature-emf relationship given by the NBS table are less than the spread between the temperature-emf relationships of the thermocouples tested in this investigation. The difference at $1600{ }^{\circ} \mathrm{C}$ is 19 $\mu \mathrm{V}$ or about $1.6 \mathrm{deg} \mathrm{C}$ while the maximum difference occurs at $1800{ }^{\circ} \mathrm{C}$ and is only $33 \mu \mathrm{V}$ or about $2.9 \mathrm{deg} \mathrm{C}$. This indicates that the thermocouples used by Obrowski and Prinz in establishing the new Degussa reference curve had essentially the same characteristics as the Pt-29.60 percent $\mathrm{Rh}$ versus $\mathrm{Pt}-6.12$ percent $\mathrm{Rh}$ thermocouples produced by American manufacturers.

The fact that the emf developed by the $30-6$ thermocouple is relatively small (about two-thirds the emf of the $\mathrm{Pt}-10$ percent $\mathrm{Rh}$ versus $\mathrm{Pt}$ thermocouple at 1700 ${ }^{\circ} \mathrm{C}$ as shown in fig. 1) imposes no particular restrictions on the use of the thermocouple at high temperatures. The thermoelectric power or sensitivity of the

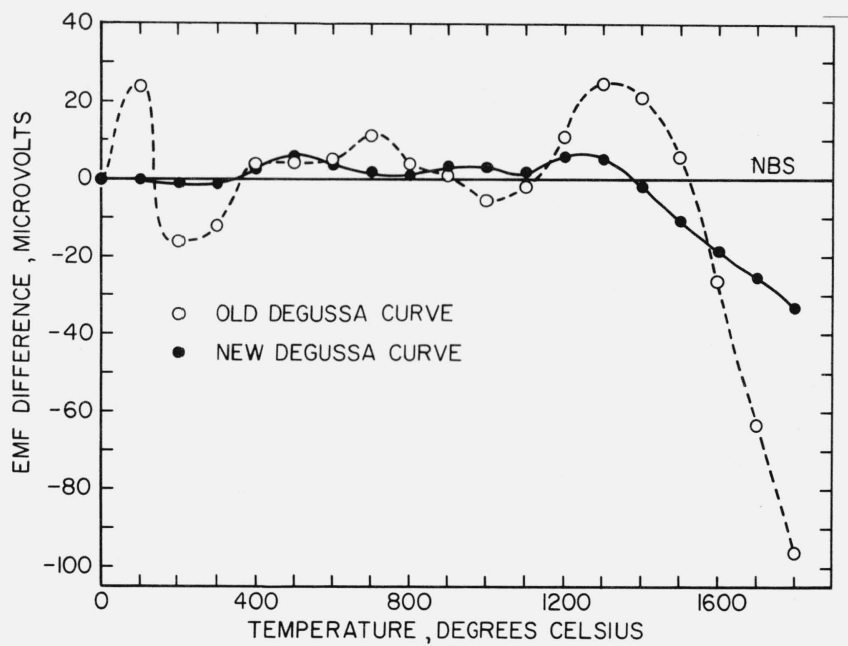

FigURE 12. Emf difference between Degussa reference curves (old and new) and NBS reference table for 30-6 thermocouple. Emf difference equals emf of Degussa curves minus emf of NBS reference table.

thermocouple above $1100{ }^{\circ} \mathrm{C}$, which is most important, is fairly high $\left(>9 \mu \mathrm{V} /{ }^{\circ} \mathrm{C}\right)$ and compares favorably with the thermoelectric power of the Pt-10 percent Rh versus $\mathrm{Pt}$ thermocouple as shown in figure 5 . One advantage of the $30-6$ thermocouple over most other types of thermocouples, is that the thermoelectric power and emf of the thermocouple are almost negligible in the normal room temperature range. Consequently, in most applications the reference junction temperature of the thermocouple does not need to be controlled or even known as long as it is between 0 and $50{ }^{\circ} \mathrm{C}$. For example, as shown by the reference tables the emf developed by the thermocouple with the reference junctions at $0{ }^{\circ} \mathrm{C}$ undergoes a reversal in sign at about $41{ }^{\circ} \mathrm{C}$, and between 0 and $50{ }^{\circ} \mathrm{C}$ varies from a minimum of about $-2 \mu \mathrm{V}$ at about $20^{\circ} \mathrm{C}$ to a maximum of about $+3 \mu \mathrm{V}$ at $50{ }^{\circ} \mathrm{C}$. Therefore, in use, if the reference junctions of the thermocouple are both at the same temperature and within the range 0 to $50{ }^{\circ} \mathrm{C}$, then a $0{ }^{\circ} \mathrm{C}$ reference junction temperature can be assumed and the error introduced will not exceed $3 \mu \mathrm{V}$. At high temperatures (above $1100{ }^{\circ} \mathrm{C}$ ) an additional error of $3 \mu \mathrm{V}$ (about $0.3 \mathrm{deg}$ ) in the measurements would be insignificant in most instances.

The arbitrary nature of the reference tables reported in this paper should be emphasized. The tables are intended only to accurately represent the general shape of the temperature-emf curve for the $30-6$ thermocouple, and should not be expected to represent the actual emf, even for a thermocouple having exactly the composition given (Pt-29.60\% $\mathrm{Rh}$ versus $\mathrm{Pt}-6.12 \% \mathrm{Rh}$ ).

In general, the temperature-emf relationship of a particular 30-6 thermocouple will deviate somewhat from the relationship given by the reference table. The deviation can be expected to be rather small and vary smoothly as shown by the curves in figures 6 and 11. Consequently, a deviation curve from the refer- 
ence table can be constructed that will yield a calibration sufficiently accurate for most purposes, by calibrating a particular thermocouple at relatively few temperatures. The uncertainties in interpolated emf values calculated for the thermocouple from the deviation curve will then depend upon the number and spacing of the calibration points used in constructing the deviation curve, the uncertainty in the calibration points, and the quality or "accuracy" of the reference table. Obviously, the quality or "accuracy" of the reference table will depend to a certain extent on the accuracy of the measurements upon which the table is based and upon the method employed for constructing the table from the measured data.

The inaccuracies introduced in the reference table for the 30-6 thermocouple by the method employed for interpolating between the measured data are not believed to be significant. Almost any interpolation scheme will give an adequate representation of the data since there is an abundance of data and the temperature intervals between the data points are small. Therefore, any inaccuracy in the shape of the temperature-emf relationship given by the table is attributed for the most part to uncertainties in the measurements.

At temperatures below $450{ }^{\circ} \mathrm{C}$ the thermoelectric power of the 30-6 thermocouple becomes quite small. Hence, the accuracy of the measurements is limited in this range by inhomogeneities in the thermocouple materials and by limitations in the testing facilities and measuring equipment, rather than by uncertainties in the calibration of the standard instrument (platinum resistance thermometer) used for measuring the temperature. - In the range 450 to $1063{ }^{\circ} \mathrm{C}$ the accuracy is limited primarily by uncertainties in the calibration of the platinum-10 percent rhodium versus platinum thermocouples used in the measurements for determining the temperature. Similarly the accuracy of the measurements above $1063{ }^{\circ} \mathrm{C}$ is limited by uncertainties in the calibration of the optical pyrometer. In addition, factors such as electrical leakage through the insulating parts and changes in the chemical composition of the wires may contribute to the uncertainty in the measurements above $1063{ }^{\circ} \mathrm{C}$. Changes in the chemical composition of the wires may result from chemical contamination, preferential loss of platinum or rhodium by oxidation and volatilization, and rhodium migration. Considering the thermocouple wire sizes used, the quality and sizes of the alumina insulating tubes used, and the rather short exposure times involved, none of the factors are believed to introduce any significant uncertainty in the measurements for temperature up to about $1600{ }^{\circ} \mathrm{C}$. However, above about $1600{ }^{\circ} \mathrm{C}$ the factors become more serious.

In preliminary experiments, beryllia $(\mathrm{BeO})$ insulating tubes were found to have higher electrical resistance in the 1600 to $1790{ }^{\circ} \mathrm{C}$ range than alumina tubes by a factor of two or more. Consequently, the thermocouples were insulated with $\mathrm{BeO}$ insulating tubes for measurements in the range above $1600{ }^{\circ} \mathrm{C}$. Even so, electrical conduction through the $\mathrm{BeO}$ insulating tubes is believed to have produced a small error in the measurements. From determinations made on the insula- tion resistance of the $\mathrm{BeO}$ tubes, by measuring the resistance between the wires of thermocouples with their measuring junctions open, the magnitude of the error is estimated not to exceed $0.5 \mathrm{deg} \mathrm{C}$ for temperatures up to $1790{ }^{\circ} \mathrm{C}$.

Some significant shifts in the thermoelectric characteristics of the thermocouples occurred as a result of testing in the 1600 to $1790{ }^{\circ} \mathrm{C}$ range. The shifts were detected by measuring the emf of the thermocouples at a lower temperature $\left(1063{ }^{\circ} \mathrm{C}\right)$ before and after the measurements in the 1600 to $1790{ }^{\circ} \mathrm{C}$ range and were attributed to changes in the chemical composition of the thermocouple wires. Chemical contamination by impurities transferred from the insulating and protecting parts was believed to have been the principal cause of the compositional changes. The error introduced in the measurements above $1600{ }^{\circ} \mathrm{C}$ because of the compositional changes in the thermocouple wires is estimated to be not more than about $1 \mathrm{deg} \mathrm{C}$.

Another source of error in the measurements above $1063{ }^{\circ} \mathrm{C}$ is introduced by the alumina "blackbodies." In all the measurements with the optical pyrometer the spectral emissivities of the alumina "blackbodies" at a wavelength of $0.65 \mu$ were taken as 1 . Consequently, any departure in the spectral emissivities from 1 will produce an error in the measurements. The spectral emissivity or quality of a blackbody depends upon the internal dimensions of the blackbody cavity, the nature of the internal reflections (diffuse or specular), the values of the reflection factor, and the temperature distribution over the cavity walls [9]. Assuming uniform temperature of the cavity walls and using the calculations described by DeVos [9] with an experimentally determined value for the partial reflectivity of alumina, the spectral emissivities at a wavelength of $0.65 \mu$ of the alumina "blackbodies" are estimated to be about 0.999 . A departure of 0.001 in the spectral emissivities of the alumina "blackbodies" from the assumed value of 1 produces an uncertainty of less than $0.2{ }^{\circ} \mathrm{C}$ in the measurements in the range 1063 to $1790{ }^{\circ} \mathrm{C}$. However, the temperature distributions along the walls of the blackbody cavities or sight holes were not uniform during the measurements. The temperature gradient along the alumina "blackbody" which was heated in the Pt-Rh wire wound tube furnace seldom exceeded more than $1 \mathrm{deg}$ per inch. This would have a negligible effect upon the spectral emissivity of the blackbody cavity, but would introduce an additional error in the measurements. When there was a temperature gradient along the alumina "blackbody" the measuring junction of the thermocouple being tested would not have been at the temperature of the back wall of the blackbody cavity, since it was located approximately $1 / 8$ in. from the cavity wall. Errors introduced by temperature gradients in the alumina "blackbody" are estimated not to exceed more than 0.2 or $0.3 \mathrm{deg}$ for measurements in the $\mathrm{Pt}-\mathrm{Rh}$ wire wound tube furnace.

The quality of the alumina "blackbodies" is verified experimentally by the good agreement (about $0.5 \mathrm{deg}$ ) achieved at $1063{ }^{\circ} \mathrm{C}$ between the calibrations of the 
various $30-6$ thermocouples determined by comparison with the standard thermocouple (sec. 4.1a and 4.1e) and by comparison with the optical pyrometer (sec. 4.1f). The agreement achieved between the two methods of calibration really reflects the accuracy of the entire system since the quality of the furnace, thermocouples, optical pyrometer calibration and blackbody influence the agreement.

The results of other tests described in this paper also give some experimental verification to the accuracy of the measurements above $1063^{\circ} \mathrm{C}$. The calibrations of thermocouples by direct comparison with the optical pyrometer which were performed in both the silicon carbide tube furnace (sec. 4.1c) and the $\mathrm{Pt}-\mathrm{Rh}$ wire wound tube furnace (sec. 4.1f) were in agreement to within about $0.5 \operatorname{deg} \mathrm{C}$ at $1063{ }^{\circ} \mathrm{C}$ and to within about $2 \operatorname{deg} \mathrm{C}$ at temperatures up to $1600{ }^{\circ} \mathrm{C}$. In general, the calibrations in the $\mathrm{Pt}-\mathrm{Rh}$ wire wound tube furnace yielded slightly higher emfs for the thermocouples than the calibrations performed in the $\mathrm{SiC}$ tube furnace. The calibrations in the Pt-Rh wire wound tube furnace were considered more reliable since problems with electrical leakage, hazing and nonuniformity of temperature were experienced in the $\mathrm{SiC}$ tube furnace. For this reason, the data obtained in the calibrations performed in the $\mathrm{SiC}$ tube furnace were not used in the calculation of the reference table. Even though the measurements made in the $\mathrm{SiC}$ tube furnace may be questionable, the agreement between the calibrations made in the two different furnaces does give added confidence in the measurements. Further confidence in the measurements above $1063{ }^{\circ} \mathrm{C}$ is gained by the agreement achieved between calibrations of thermocouples determined by direct comparison with standard Pt-10 percent $\mathrm{Rh}$ versus $\mathrm{Pt}$ thermocouples (sec. 4.1e) and by direct comparison with the optical pyrometer (sec. 4.1f). Calibrations of the same thermocouples by the two different methods agree to within $1 \mathrm{deg} C$ in the range 1063 to $1350{ }^{\circ} \mathrm{C}$ and to within about $2 \mathrm{deg} \mathrm{C}$ up to $1450{ }^{\circ} \mathrm{C}$. This agreement is quite satisfactory, since the calibrations of the standard $\mathrm{Pt}-10$ percent $\mathrm{Rh}$ versus $\mathrm{Pt}$ thermocouples were obtained by extrapolation above $1063^{\circ} \mathrm{C}$ and are estimated to be uncertain by $2 \operatorname{deg} \mathrm{C}$ at $1450^{\circ} \mathrm{C}$.

Since the $30-6$ thermocouple is primarily intended for use in the range above $1063^{\circ} \mathrm{C}$, particular emphasis is placed upon the accuracy of the measurements in this range. Other tests, which are not described in this paper, were performed in hope of gaining more insight into the accuracy of the measurements. For example several $30-6$ thermocouples were calibrated at the melting points of palladium $\left(1552{ }^{\circ} \mathrm{C}\right)$ and platinum $\left(1769{ }^{\circ} \mathrm{C}\right)$ by the wire method [10], and these calibrations differed from calibrations based upon comparison with an optical pyrometer by no more than about $1 \operatorname{deg} \mathrm{C}$ at the melting point of palladium and by no more than $2 \mathrm{deg} \mathrm{C}$ at the melting point of platinum. These differences were not considered unreasonable since the measurements by the wire method were estimated to be uncertain by about $1.5 \mathrm{deg} C$ at the melting point of palladium and 2 or $3 \mathrm{deg} C$ at the melting point of platinum. Several $30-6$ thermocouples were also calibrated in a vertical "blackbody" furnace [11] at temperatures up to $1600{ }^{\circ} \mathrm{C}$ in an helium atmosphere and a different calibrated optical pyrometer was used to determine the temperature. These calibrations were in agreement with calibrations of the thermocouples performed in air in the $\mathrm{Pt}-\mathrm{Rh}$ wire wound tube furnace to within about $2 \operatorname{deg} \mathrm{C}$ up to $1600{ }^{\circ} \mathrm{C}$. In another test, a 30-6 thermocouple was calibrated by direct comparison with a calibrated Leeds and Northrup type 8640 photoelectric pyrometer in the range 1063 to $1555^{\circ} \mathrm{C}$. The thermocouple was heated in the $\mathrm{Pt}-\mathrm{Rh}$ wire wound furnace. The difference between this calibration and a calibration of the thermocouple in the same furnace, but using the visual optical pyrometer to determine the temperature, varied from about $0.5 \mathrm{deg} \mathrm{C}$ at $1063^{\circ} \mathrm{C}$ to about $1.5 \mathrm{deg} \mathrm{C}$ at $1555^{\circ} \mathrm{C}$.

After considering the capabilities of the standard instruments and test facilities used, the quality and stability of the thermocouples tested, and the results of the various tests performed, the uncertainties in the measurements that were used in calculating the reference table are estimated not to exceed $\pm 2 \mu \mathrm{V}$ in the range 0 to $450{ }^{\circ} \mathrm{C}$ and about $\pm 3 \mu \mathrm{V}$ in the range 450 to $1063{ }^{\circ} \mathrm{C}$. The uncertainties in the measurements increased above $1063{ }^{\circ} \mathrm{C}$ and are estimated not to exceed the equivalent of about $\pm 2 \operatorname{deg} \mathrm{C}$ at $1400{ }^{\circ} \mathrm{C}$, and about \pm 3 or $4 \operatorname{deg} \mathrm{C}$ at $1750^{\circ} \mathrm{C}$. Furthermore, it is estimated that determinations of the emf of a particular 30-6 thermocouple at about 600,1063 , and $1300{ }^{\circ} \mathrm{C}$ by comparison with a standard $\mathrm{Pt}-10$ percent $\mathrm{Rh}$ versus $\mathrm{Pt}$ thermocouple and at the melting point of palladium $\left(1552{ }^{\circ} \mathrm{C}\right)$ by the melting wire method will be sufficient to construct a deviation curve from the reference table such that the resulting calibration will be accurate to within $\pm 6 \mu \mathrm{V}$ up to $1063{ }^{\circ} \mathrm{C}$, the equivalent of about $\pm 3 \operatorname{deg} \mathrm{C}$ up to $1550{ }^{\circ} \mathrm{C}$, and the equivalent of about $\pm 5 \operatorname{deg} \mathrm{C}$ above.

Calibration of other $30-6$ thermocouples can then be determined rather easily by directly comparing them with a calibrated 30-6 thermocouple. In any event, calibration of 30-6 thermocouples by direct comparison with an optical pyrometer will generally prove undesirable, since the method is tedious, time consuming, and requires rather elaborate facilities and techniques. Also, actual calibration of the thermocouples above about $1600{ }^{\circ} \mathrm{C}$ seems undesirable in most instances, since it is likely to introduce some instability in the thermocouple and render it less reliable in use. Calibration values above $1600{ }^{\circ} \mathrm{C}$ can be obtained accurately by extrapolating the deviation curve.

Based upon the experience gained at NBS with the 30-6 thermocouple during the present studies, the following information is summarized for the thermocouple.

(1) Nearly all 30-6 thermocouples produced by manufacturers in this country will have temperatureemf relationships that agree with the temperature-emf relationship given by the reference table to within the equivalent of \pm 0.5 percent of the temperature in the range 500 to $1800^{\circ} \mathrm{C}$ and to within $\pm 15 \mu \mathrm{V}$ for temperatures below $500{ }^{\circ} \mathrm{C}$. 
(2) Calibration of a particular 30-6 thermocouple at four points (about $600,1063,1300$, and $1552{ }^{\circ} \mathrm{C}$ ) will be sufficient to construct a deviation curve from the reference table such that the resulting calibration will be accurate to within $\pm 6 \mu \mathrm{V}$ up to $1063^{\circ} \mathrm{C}$, the equivalent of about $\pm 3{ }^{\circ} \mathrm{C}$ up to $1552{ }^{\circ} \mathrm{C}$, and the equivalent of about $\pm 5{ }^{\circ} \mathrm{C}$ above.

(3) Actual calibration of the thermocouple above about $1600{ }^{\circ} \mathrm{C}$ is not recommended, since some instability may result in the thermocouple. Values above 1600 ${ }^{\circ} \mathrm{C}$ may be accurately determined by extrapolation.

(4) High purity alumina is recommended for insula- tion and protection of the thermocouple but caution should be exercised at temperatures above about 1600 ${ }^{\circ} \mathrm{C}$ for errors introduced by the electrical conductance of the insulators.

(5) The use of large diameter wires (at least $0.020 \mathrm{in}$.) and larger size insulating tubes is recommended for operating temperatures above 1500 or $1600^{\circ} \mathrm{C}$, so as to give the thermocouple added strength and to minimize errors due to electrical leakage.

(6) In most instances the reference junction temperature need not be controlled since the emf and thermoelectric power of the thermocouple at normal room temperatures are very small.

\section{Appendix}

TABLE 1A. Platinum-30 percent Rhodium versus Platinum-6 Percent Rhodium Thermocouples (Temperatures in Degrees C(Int. 1948). Electromotive Force in Absolute Millivolts. Reference Junctions at $0{ }^{\circ} \mathrm{C}$.)

\begin{tabular}{lllllllllllllll}
\hline${ }^{\circ} \mathrm{C}$ & $\mathbf{0}$ & 1 & 2 & 3 & 4 & 5 & 6 & 7 & 9 & \\
\hline
\end{tabular}

Millivolts

\begin{tabular}{|c|c|c|c|c|c|c|c|c|c|c|}
\hline 0 & -0 & -0.000 & -0.000 & -0.001 & -0.001 & -0.001 & -0.001 & -0.001 & -0.002 & -0.002 \\
\hline $\begin{array}{l}10 \\
20 \\
30\end{array}$ & $\begin{array}{l}-0.002 \\
-0.002 \\
-0.002\end{array}$ & $\begin{array}{l}-0.002 \\
-0.002 \\
-0.002\end{array}$ & $\begin{array}{l}-0.002 \\
-0.002 \\
-0.002\end{array}$ & $\begin{array}{l}-0.002 \\
-0.002 \\
-0.002\end{array}$ & $\begin{array}{l}-0.002 \\
-0.002 \\
-0.001\end{array}$ & $\begin{array}{l}-0.002 \\
-0.002 \\
-0.001\end{array}$ & $\begin{array}{l}-0.002 \\
-0.002 \\
-0.001\end{array}$ & $\begin{array}{l}-0.002 \\
-0.002 \\
-0.001\end{array}$ & $\begin{array}{l}-0.002 \\
-0.002 \\
-0.001\end{array}$ & $\begin{array}{l}-0.002 \\
-0.002 \\
-0.001\end{array}$ \\
\hline $\begin{array}{l}40 \\
50 \\
60\end{array}$ & $\begin{array}{r}-0.000 \\
0.002 \\
0.006\end{array}$ & $\begin{array}{r}-0.000 \\
0.003 \\
0.007\end{array}$ & $\begin{array}{l}0.000 \\
0.003 \\
0.007\end{array}$ & $\begin{array}{l}0.000 \\
0.004 \\
0.008\end{array}$ & $\begin{array}{l}0.001 \\
0.004 \\
0.008\end{array}$ & $\begin{array}{l}0.001 \\
0.004 \\
0.009\end{array}$ & $\begin{array}{l}0.001 \\
0.005 \\
0.009\end{array}$ & $\begin{array}{l}0.002 \\
0.005 \\
0.010\end{array}$ & $\begin{array}{l}0.002 \\
0.006 \\
0.010\end{array}$ & $\begin{array}{l}0.002 \\
0.006 \\
0.011\end{array}$ \\
\hline $\begin{array}{l}70 \\
80 \\
90\end{array}$ & $\begin{array}{l}0.011 \\
0.018 \\
0.025\end{array}$ & $\begin{array}{l}0.012 \\
0.018 \\
0.026\end{array}$ & $\begin{array}{l}0.013 \\
0.019 \\
0.027\end{array}$ & $\begin{array}{l}0.013 \\
0.020 \\
0.027\end{array}$ & $\begin{array}{l}0.014 \\
0.020 \\
0.028\end{array}$ & $\begin{array}{l}0.014 \\
0.021 \\
0.029\end{array}$ & $\begin{array}{l}0.015 \\
0.022 \\
0.030\end{array}$ & $\begin{array}{l}0.016 \\
0.023 \\
0.031\end{array}$ & $\begin{array}{l}0.016 \\
0.023 \\
0.032\end{array}$ & $\begin{array}{l}0.017 \\
0.024 \\
0.032\end{array}$ \\
\hline 100 & 0.033 & 0.034 & 0.035 & 0.036 & 0.037 & 0.038 & 0.039 & 0.040 & 0.041 & 0.042 \\
\hline $\begin{array}{l}110 \\
120 \\
130\end{array}$ & $\begin{array}{l}0.043 \\
0.054 \\
0.065\end{array}$ & $\begin{array}{l}0.044 \\
0.055 \\
0.066\end{array}$ & $\begin{array}{l}0.045 \\
0.056 \\
0.068\end{array}$ & $\begin{array}{l}0.046 \\
0.057 \\
0.069\end{array}$ & $\begin{array}{l}0.047 \\
0.058 \\
0.070\end{array}$ & $\begin{array}{l}0.048 \\
0.059 \\
0.072\end{array}$ & $\begin{array}{l}0.049 \\
0.060 \\
0.073\end{array}$ & $\begin{array}{l}0.050 \\
0.062 \\
0.074\end{array}$ & $\begin{array}{l}0.051 \\
0.063 \\
0.075\end{array}$ & $\begin{array}{l}0.052 \\
0.064 \\
0.077\end{array}$ \\
\hline $\begin{array}{l}140 \\
150 \\
160\end{array}$ & $\begin{array}{l}0.078 \\
0.092 \\
0.107\end{array}$ & $\begin{array}{l}0.079 \\
0.094 \\
0.109\end{array}$ & $\begin{array}{l}0.081 \\
0.095 \\
0.110\end{array}$ & $\begin{array}{l}0.082 \\
0.096 \\
0.112\end{array}$ & $\begin{array}{l}0.084 \\
0.098 \\
0.113\end{array}$ & $\begin{array}{l}0.085 \\
0.099 \\
0.115\end{array}$ & $\begin{array}{l}0.086 \\
0.101 \\
0.117\end{array}$ & $\begin{array}{l}0.088 \\
0.102 \\
0.118\end{array}$ & $\begin{array}{l}0.089 \\
0.104 \\
0.120\end{array}$ & $\begin{array}{l}0.091 \\
0.106 \\
0.122\end{array}$ \\
\hline $\begin{array}{l}170 \\
180 \\
190\end{array}$ & $\begin{array}{l}0.123 \\
0.140 \\
0.159\end{array}$ & $\begin{array}{l}0.125 \\
0.142 \\
0.161\end{array}$ & $\begin{array}{l}0.127 \\
0.144 \\
0.163\end{array}$ & $\begin{array}{l}0.128 \\
0.146 \\
0.164\end{array}$ & $\begin{array}{l}0.130 \\
0.148 \\
0.166\end{array}$ & $\begin{array}{l}0.132 \\
0.149 \\
0.168\end{array}$ & $\begin{array}{l}0.133 \\
0.151 \\
0.170\end{array}$ & $\begin{array}{l}0.135 \\
0.153 \\
0.172\end{array}$ & $\begin{array}{l}0.137 \\
0.155 \\
0.174\end{array}$ & $\begin{array}{l}0.139 \\
0.157 \\
0.176\end{array}$ \\
\hline 200 & 0.178 & 0.180 & 0.182 & 0.184 & 0.186 & 0.188 & 0.190 & 0.192 & 0.194 & 0.197 \\
\hline $\begin{array}{l}210 \\
220 \\
230\end{array}$ & $\begin{array}{l}0.199 \\
0.220 \\
0.243\end{array}$ & $\begin{array}{l}0.201 \\
0.222 \\
0.245\end{array}$ & $\begin{array}{l}0.203 \\
0.225 \\
0.247\end{array}$ & $\begin{array}{l}0.205 \\
0.227 \\
0.250\end{array}$ & $\begin{array}{l}0.207 \\
0.229 \\
0.252\end{array}$ & $\begin{array}{l}0.209 \\
0.231 \\
0.254\end{array}$ & $\begin{array}{l}0.211 \\
0.234 \\
0.257\end{array}$ & $\begin{array}{l}0.214 \\
0.236 \\
0.259\end{array}$ & $\begin{array}{l}0.216 \\
0.238 \\
0.262\end{array}$ & $\begin{array}{l}0.218 \\
0.240 \\
0.264\end{array}$ \\
\hline $\begin{array}{l}240 \\
250 \\
260\end{array}$ & $\begin{array}{l}0.266 \\
0.291 \\
0.317\end{array}$ & $\begin{array}{l}0.269 \\
0.294 \\
0.320\end{array}$ & $\begin{array}{l}0.271 \\
0.296 \\
0.322\end{array}$ & $\begin{array}{l}0.274 \\
0.299 \\
0.325\end{array}$ & $\begin{array}{l}0.276 \\
0.301 \\
0.328\end{array}$ & $\begin{array}{l}0.279 \\
0.304 \\
0.330\end{array}$ & $\begin{array}{l}0.281 \\
0.306 \\
0.333\end{array}$ & $\begin{array}{l}0.284 \\
0.309 \\
0.336\end{array}$ & $\begin{array}{l}0.286 \\
0.312 \\
0.338\end{array}$ & $\begin{array}{l}0.289 \\
0.314 \\
0.341\end{array}$ \\
\hline $\begin{array}{l}270 \\
280 \\
290\end{array}$ & $\begin{array}{l}0.344 \\
0.372 \\
0.401\end{array}$ & $\begin{array}{l}0.347 \\
0.374 \\
0.404\end{array}$ & $\begin{array}{l}0.349 \\
0.377 \\
0.406\end{array}$ & $\begin{array}{l}0.352 \\
0.380 \\
0.409\end{array}$ & $\begin{array}{l}0.355 \\
0.383 \\
0.412\end{array}$ & $\begin{array}{l}0.358 \\
0.386 \\
0.415\end{array}$ & $\begin{array}{l}0.360 \\
0.389 \\
0.418\end{array}$ & $\begin{array}{l}0.363 \\
0.392 \\
0.421\end{array}$ & $\begin{array}{l}0.366 \\
0.395 \\
0.424\end{array}$ & $\begin{array}{l}0.369 \\
0.398 \\
0.427\end{array}$ \\
\hline
\end{tabular}


TAble 1A. Platinum-30 percent Rhodium versus Platinum-6 Percent Rhodium Thermocouples-Continued (Temperatures in Degrees C(Int. 1948). Electromotive Force in Absolute Millivolts. Reference Junctions at $0{ }^{\circ} \mathrm{C}$.)

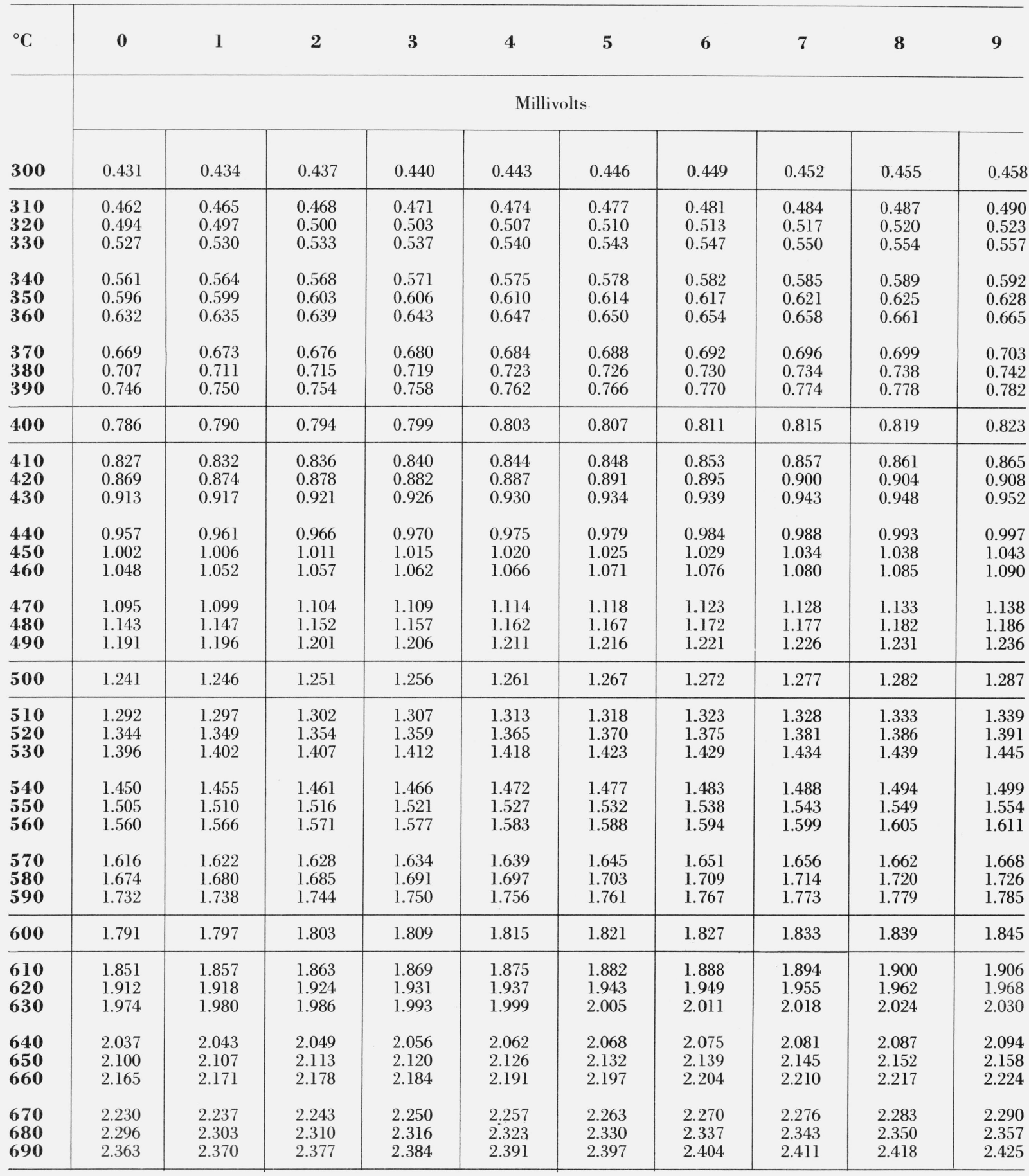


TABle 1A. Platinum-30 percent Rhodium versus Platinum-6 Percent Rhodium Thermocouples-Continued (Temperatures in Degrees C(Int. 1948). Electromotive Force in Absolute Millivolts. Reference Junctions at $0{ }^{\circ} \mathrm{C}$.)

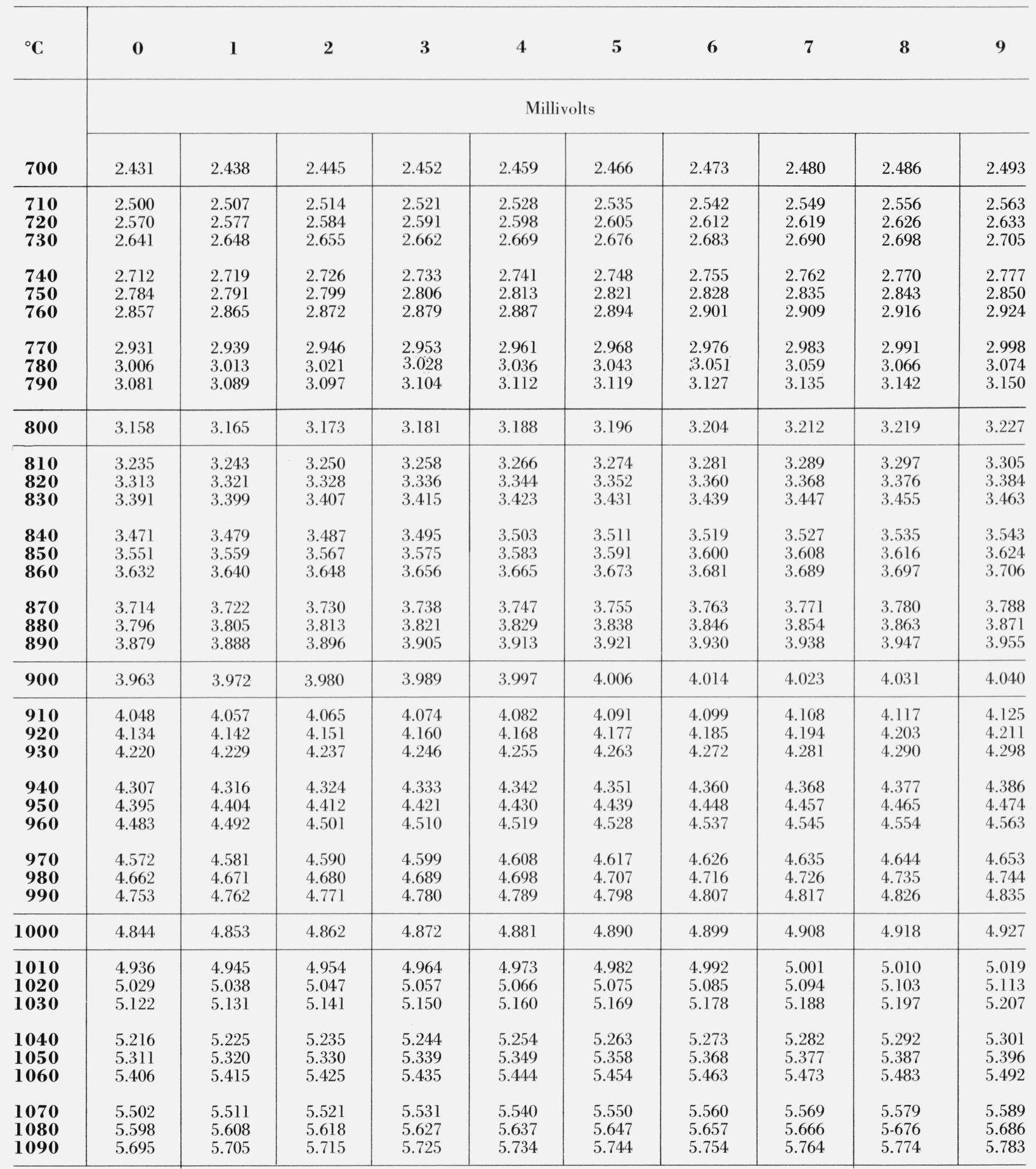


TABle 1A. Platinum-30 percent Rhodium versus Platinum-6 Percent Rhodium Thermocouples-Continued (Temperatures in Degrees C(Int. 1948). Electromotive Force in Absolute Millivolts. Reference Junctions at $0{ }^{\circ} \mathrm{C}$.)

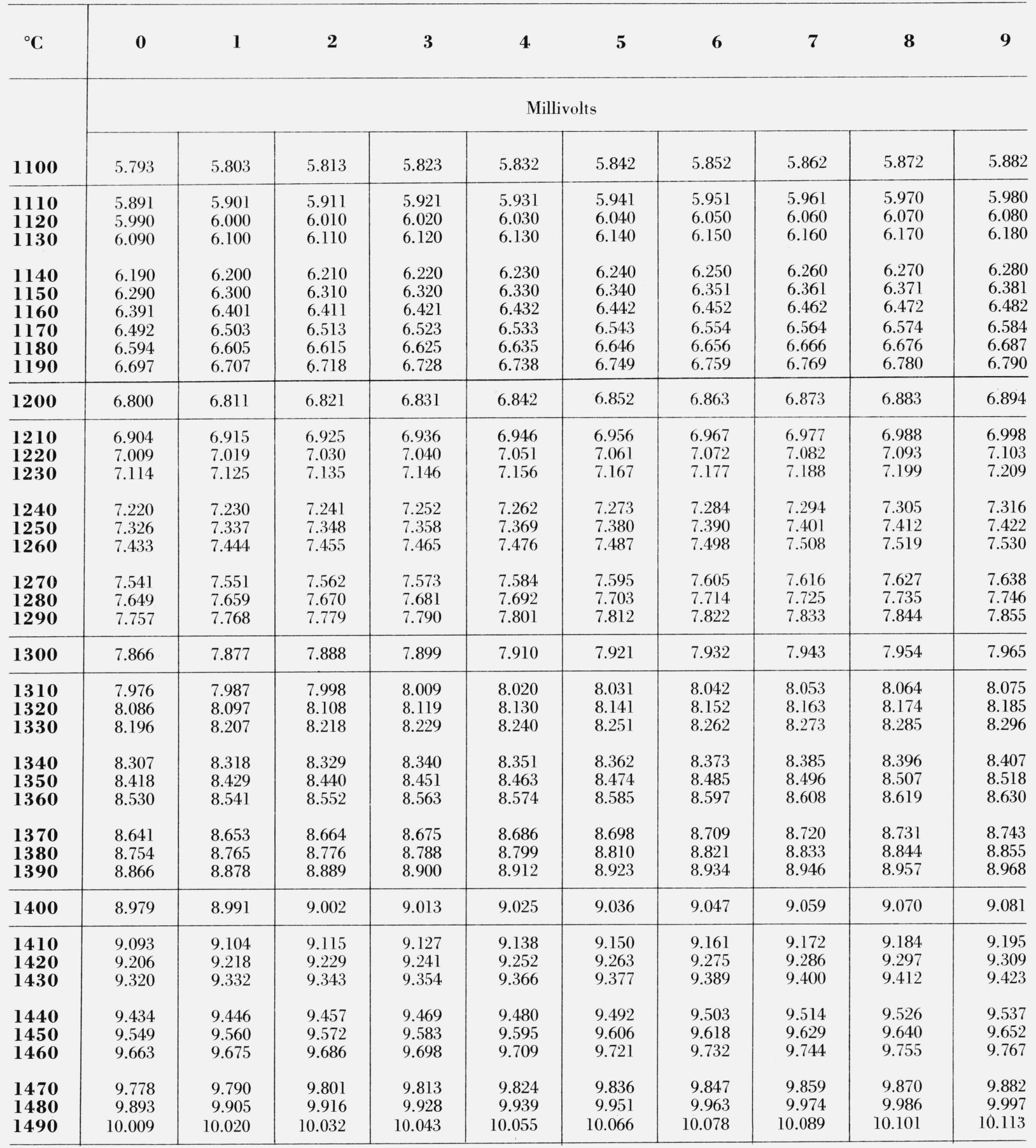


TABle 1A. Platinum-30 percent Rhodium versus Platinum-6 Percent Rhodium Thermocouples-Continued (Temperatures in Degrees C(Int. 1948). Electromotive Force in Absolute Millivolts. Reference Junctions at $0{ }^{\circ} \mathrm{C}$.)

\begin{tabular}{|c|c|c|c|c|c|c|c|c|c|c|}
\hline${ }^{\circ} \mathrm{C}$ & 0 & 1 & 2 & 3 & 4 & 5 & 6 & 7 & 8 & 9 \\
\hline \multirow[b]{2}{*}{1500} & \multicolumn{10}{|c|}{ Millivolts } \\
\hline & 10.124 & 10.136 & 10.147 & 10.159 & 10.170 & 10.182 & 10.193 & 10.205 & 10.217 & 10.228 \\
\hline $\begin{array}{l}1510 \\
1520 \\
1530\end{array}$ & $\begin{array}{l}10.240 \\
10.356 \\
10.471\end{array}$ & $\begin{array}{l}10.251 \\
10.367 \\
10.483\end{array}$ & $\begin{array}{l}10.263 \\
10.379 \\
10.495\end{array}$ & $\begin{array}{l}10.274 \\
10.390 \\
10.506\end{array}$ & $\begin{array}{l}10.286 \\
10.402 \\
10.518\end{array}$ & $\begin{array}{l}10.298 \\
10.413 \\
10.529\end{array}$ & $\begin{array}{l}10.309 \\
10.425 \\
10.541\end{array}$ & $\begin{array}{l}10.321 \\
10.437 \\
10.553\end{array}$ & $\begin{array}{l}10.332 \\
10.448 \\
10.564\end{array}$ & $\begin{array}{l}10.344 \\
10.460 \\
10.576\end{array}$ \\
\hline $\begin{array}{l}1540 \\
1550 \\
1560\end{array}$ & $\begin{array}{l}10.587 \\
10.704 \\
10.820\end{array}$ & $\begin{array}{l}10.599 \\
10.715 \\
10.832\end{array}$ & $\begin{array}{l}10.611 \\
10.727 \\
10.843\end{array}$ & $\begin{array}{l}10.622 \\
10.739 \\
10.855\end{array}$ & $\begin{array}{l}10.634 \\
10.750 \\
10.866\end{array}$ & $\begin{array}{l}10.646 \\
10.762 \\
10.878\end{array}$ & $\begin{array}{l}10.657 \\
10.773 \\
10.890\end{array}$ & $\begin{array}{l}10.669 \\
10.785 \\
10.901\end{array}$ & $\begin{array}{l}10.680 \\
10.797 \\
10.913\end{array}$ & $\begin{array}{l}10.692 \\
10.808 \\
10.925\end{array}$ \\
\hline $\begin{array}{l}1570 \\
1580 \\
1590\end{array}$ & $\begin{array}{l}10.936 \\
11.053 \\
11.169\end{array}$ & $\begin{array}{l}10.948 \\
11.064 \\
11.181\end{array}$ & $\begin{array}{l}10.960 \\
11.076 \\
11.193\end{array}$ & $\begin{array}{l}10.971 \\
11.088 \\
11.204\end{array}$ & $\begin{array}{l}10.983 \\
11.099 \\
11.216\end{array}$ & $\begin{array}{l}10.995 \\
11.111 \\
11.228\end{array}$ & $\begin{array}{l}11.006 \\
11.123 \\
11.239\end{array}$ & $\begin{array}{l}11.018 \\
11.134 \\
11.251\end{array}$ & $\begin{array}{l}11.029 \\
11.146 \\
11.263\end{array}$ & $\begin{array}{l}11.041 \\
11.158 \\
11.274\end{array}$ \\
\hline 1600 & 11.286 & 11.298 & 11.309 & 11.321 & 11.333 & 11.344 & 11.356 & 11.368 & 11.379 & 11.391 \\
\hline $\begin{array}{l}1610 \\
1620 \\
1630\end{array}$ & $\begin{array}{l}11.403 \\
11.519 \\
11.636\end{array}$ & $\begin{array}{l}11.414 \\
11.531 \\
11.648\end{array}$ & $\begin{array}{l}11.426 \\
11.543 \\
11.659\end{array}$ & $\begin{array}{l}11.438 \\
11.554 \\
11.671\end{array}$ & $\begin{array}{l}11.449 \\
11.566 \\
11.683\end{array}$ & $\begin{array}{l}11.461 \\
11.578 \\
11.694\end{array}$ & $\begin{array}{l}11.473 \\
11.589 \\
11.706\end{array}$ & $\begin{array}{l}11.484 \\
11.601 \\
11.718\end{array}$ & $\begin{array}{l}11.496 \\
11.613 \\
11.729\end{array}$ & $\begin{array}{l}11.508 \\
11.624 \\
11.741\end{array}$ \\
\hline $\begin{array}{l}1640 \\
1650 \\
1660\end{array}$ & $\begin{array}{l}11.753 \\
11.869 \\
11.986\end{array}$ & $\begin{array}{l}11.764 \\
11.881 \\
11.998\end{array}$ & $\begin{array}{l}11.776 \\
11.893 \\
12.010\end{array}$ & $\begin{array}{l}11.788 \\
11.905 \\
12.021\end{array}$ & $\begin{array}{l}11.799 \\
11.916 \\
12.033\end{array}$ & $\begin{array}{l}11.811 \\
11.928 \\
12.045\end{array}$ & $\begin{array}{l}11.823 \\
11.940 \\
12.056\end{array}$ & $\begin{array}{l}11.834 \\
11.951 \\
12.068\end{array}$ & $\begin{array}{l}11.846 \\
11.963 \\
12.080\end{array}$ & $\begin{array}{l}11.858 \\
11.975 \\
12.091\end{array}$ \\
\hline $\begin{array}{l}1670 \\
1680 \\
1690\end{array}$ & $\begin{array}{l}12.103 \\
12.220 \\
12.336\end{array}$ & $\begin{array}{l}12.115 \\
12.231 \\
12.348\end{array}$ & $\begin{array}{l}12.126 \\
12.243 \\
12.360\end{array}$ & $\begin{array}{l}12.138 \\
12.255 \\
12.371\end{array}$ & $\begin{array}{l}12.150 \\
12.266 \\
12.383\end{array}$ & $\begin{array}{l}12.161 \\
12.278 \\
12.395\end{array}$ & $\begin{array}{l}12.173 \\
12.290 \\
12.406\end{array}$ & $\begin{array}{l}12.185 \\
12.301 \\
12.418\end{array}$ & $\begin{array}{l}12.196 \\
12.313 \\
12.430\end{array}$ & $\begin{array}{l}12.208 \\
12.325 \\
12.441\end{array}$ \\
\hline 1700 & 12.453 & 12.465 & 12.476 & 12.488 & 12.500 & 12.511 & 12.523 & 12.535 & 12.546 & 12.558 \\
\hline $\begin{array}{l}1710 \\
1720 \\
1730\end{array}$ & $\begin{array}{l}12.570 \\
12.686 \\
12.803\end{array}$ & $\begin{array}{l}12.581 \\
12.698 \\
12.814\end{array}$ & $\begin{array}{l}12.593 \\
12.709 \\
12.826\end{array}$ & $\begin{array}{l}12.605 \\
12.721 \\
12.838\end{array}$ & $\begin{array}{l}12.616 \\
12.733 \\
12.849\end{array}$ & $\begin{array}{l}12.628 \\
12.744 \\
12.861\end{array}$ & $\begin{array}{l}12.640 \\
12.756 \\
12.872\end{array}$ & $\begin{array}{l}12.651 \\
12.768 \\
12.884\end{array}$ & $\begin{array}{l}12.663 \\
12.779 \\
12.896\end{array}$ & $\begin{array}{l}12.675 \\
12.791 \\
12.907\end{array}$ \\
\hline $\begin{array}{l}1740 \\
1750 \\
1760\end{array}$ & $\begin{array}{l}12.919 \\
13.035 \\
13.152\end{array}$ & $\begin{array}{l}12.931 \\
13.047 \\
13.163\end{array}$ & $\begin{array}{l}12.942 \\
13.059 \\
13.175\end{array}$ & $\begin{array}{l}12.954 \\
13.070 \\
13.186\end{array}$ & $\begin{array}{l}12.966 \\
13.082 \\
13.198\end{array}$ & $\begin{array}{l}12.977 \\
13.093 \\
13.210\end{array}$ & $\begin{array}{l}12.989 \\
13.105 \\
13.221\end{array}$ & $\begin{array}{l}13.000 \\
13.117 \\
13.233\end{array}$ & $\begin{array}{l}13.012 \\
13.128 \\
13.245\end{array}$ & $\begin{array}{l}13.024 \\
13.140 \\
13.256\end{array}$ \\
\hline $\begin{array}{l}1770 \\
1780 \\
1790\end{array}$ & $\begin{array}{l}13.268 \\
13.384 \\
13.500\end{array}$ & $\begin{array}{l}13.279 \\
13.395 \\
13.511\end{array}$ & $\begin{array}{l}13.291 \\
13.407 \\
13.523\end{array}$ & $\begin{array}{l}13.303 \\
13.419 \\
13.534\end{array}$ & $\begin{array}{l}13.314 \\
13.430 \\
13.546\end{array}$ & $\begin{array}{l}13.326 \\
13.442 \\
13.558\end{array}$ & $\begin{array}{l}13.337 \\
13.453 \\
13.569\end{array}$ & $\begin{array}{l}13.349 \\
13.465 \\
13.581\end{array}$ & $\begin{array}{l}13.361 \\
13.477 \\
13.592\end{array}$ & $\begin{array}{l}13.372 \\
13.488 \\
13.604\end{array}$ \\
\hline 1800 & 13.616 & 13.627 & 13.639 & 13.650 & 13.662 & 13.673 & 13.685 & 13.696 & 13.708 & 13.720 \\
\hline $\begin{array}{l}1810 \\
1820\end{array}$ & $\begin{array}{l}13.731 \\
13.847\end{array}$ & 13.743 & 13.754 & 13.766 & 13.777 & 13.789 & 13.801 & 13.812 & 13.824 & 13.835 \\
\hline
\end{tabular}


Table 2A. Platinum-30 percent Rhodium versus Platinum-6 Percent Rhodium Thermocouples (Electromotive Force in Absolute Millivolts. Temperatures in Degrees C(Int. 1948). Reference Junctions at $0{ }^{\circ} \mathrm{C}$.)

\begin{tabular}{|c|c|c|c|c|c|c|c|c|c|c|}
\hline Millivolts & 0.000 & 0.010 & 0.020 & 0.030 & 0.040 & 0.050 & 0.060 & 0.070 & 0.080 & 0.090 \\
\hline \multirow[b]{2}{*}{$\mathbf{0 .}$} & \multicolumn{10}{|c|}{ Degrees C } \\
\hline & 0. & 67.3 & 83.4 & 96.2 & 107.1 & 116.8 & 125.6 & 133.8 & 141.4 & 148.6 \\
\hline 0.100 & 155.4 & 161.8 & 168.0 & 174.0 & 179.7 & 185.3 & 190.6 & 195.9 & 200.9 & 205.8 \\
\hline 0.200 & 210.7 & 215.3 & 219.9 & 224.4 & 228.8 & 233.1 & 237.3 & 241.5 & 245.5 & 249.5 \\
\hline 0.300 & 253.5 & 257.4 & 261.2 & 264.9 & 268.6 & 272.3 & 275.9 & 279.4 & 282.9 & 286.4 \\
\hline 0.400 & 289.8 & 293.2 & 296.5 & 299.8 & 303.1 & 306.3 & 309.5 & 312.7 & 315.8 & 318.9 \\
\hline 0.500 & 322.0 & 325.0 & 328.0 & 331.0 & 334.0 & 336.9 & 339.8 & 342.7 & 345.6 & 348.4 \\
\hline 0.600 & 351.2 & 354.0 & 356.8 & 359.5 & 362.2 & 364.9 & 367.6 & 370.3 & 372.9 & 375.6 \\
\hline 0.700 & 378.2 & 380.8 & 383.3 & 385.9 & 388.4 & 391.0 & 393.5 & 396.0 & 398.5 & 400.9 \\
\hline 0.800 & 403.4 & 405.8 & 408.2 & 410.6 & 413.0 & 415.4 & 417.8 & 420.1 & 422.5 & 424.8 \\
\hline 0.900 & 427.1 & 429.4 & 431.7 & 434.0 & 436.3 & 438.5 & 440.8 & 443.0 & 445.2 & 447.4 \\
\hline 1.000 & 449.6 & 451.8 & 454.0 & 456.2 & 458.4 & 460.5 & 462.7 & 464.8 & 466.9 & 469.0 \\
\hline 1.100 & 471.1 & 473.2 & 475.3 & 477.4 & 479.5 & 481.5 & 483.6 & 485.6 & 487.7 & 489.7 \\
\hline 1.200 & 491.7 & 493.7 & 495.8 & 497.8 & 499.7 & 501.7 & 503.7 & 505.7 & 507.6 & 509.6 \\
\hline 1.300 & 511.5 & 513.5 & 515.4 & 517.4 & 519.3 & 521.2 & 523.1 & 525.0 & 526.9 & 528.8 \\
\hline 1.400 & 530.7 & 532.5 & 534.4 & 536.3 & 538.1 & 540.0 & 541.8 & 543.7 & 545.5 & 547.3 \\
\hline 1.500 & 549.2 & 551.0 & 552.8 & 554.6 & 556.4 & 558.2 & 560.0 & 561.8 & 563.6 & 565.3 \\
\hline 1.600 & 567.1 & 568.9 & 570.6 & 572.4 & 574.1 & 575.9 & 577.6 & 579.3 & 581.1 & 582.8 \\
\hline 1.700 & 584.5 & 586.2 & 588.0 & 589.7 & 591.4 & 593.1 & 594.8 & 596.4 & 598.1 & 599.8 \\
\hline 1.800 & 601.5 & 603.2 & 604.8 & 606.5 & 608.1 & 609.8 & 611.5 & 613.1 & 614.7 & 616.4 \\
\hline 1.900 & 618.0 & 619.7 & 621.3 & 622.9 & 624.5 & 626.1 & 627.8 & 629.4 & 631.0 & 632.6 \\
\hline 2.000 & 634.2 & 635.8 & 637.4 & 638.9 & 640.5 & 642.1 & 643.7 & 645.3 & 646.8 & 648.4 \\
\hline 2.100 & 650.0 & 651.5 & 653.1 & 654.6 & 656.2 & 657.7 & 659.3 & 660.8 & 662.3 & 663.9 \\
\hline 2.200 & 665.4 & 666.9 & 668.5 & 670.0 & 671.5 & 673.0 & 674.5 & 676.0 & 677.5 & 679.0 \\
\hline 2.300 & 680.5 & 682.0 & 683.5 & 685.0 & 686.5 & 688.0 & 689.5 & 691.0 & 692.4 & 693.9 \\
\hline 2.400 & 695.4 & 696.9 & 698.3 & 699.8 & 701.2 & 702.7 & 704.2 & 705.6 & 707.1 & 708.5 \\
\hline 2.500 & 710.0 & 711.4 & 712.8 & 714.3 & 715.7 & 717.1 & 718.6 & 720.0 & 721.4 & 722.8 \\
\hline 2.600 & 724.3 & 725.7 & 727.1 & 728.5 & 729.9 & 731.3 & 732.7 & 734.1 & 735.5 & 736.9 \\
\hline 2.700 & 738.3 & 739.7 & 741.1 & 742.5 & 743.9 & 745.3 & 746.7 & 748.1 & 749.4 & 750.8 \\
\hline 2.800 & 752.2 & 753.6 & 754.9 & 756.3 & 757.7 & 759.0 & 760.4 & 761.7 & 763.1 & 764.5 \\
\hline 2.900 & 765.8 & 767.2 & 768.5 & 769.9 & 771.2 & 772.5 & 773.9 & 775.2 & 776.6 & 777.9 \\
\hline 3.000 & 779.2 & 780.6 & 781.9 & 783.2 & 784.5 & 785.9 & 787.2 & 788.5 & 789.8 & 791.1 \\
\hline 3.100 & 792.5 & 793.8 & 795.1 & 796.4 & 797.7 & 799.0 & 800.3 & 801.6 & 802.9 & 804.2 \\
\hline 3.200 & 805.5 & 806.8 & 808.1 & 809.4 & 810.7 & 812.0 & 813.2 & 814.5 & 815.8 & 817.1 \\
\hline 3.300 & 818.4 & 819.7 & 820.9 & 822.2 & 823.5 & 824.7 & 826.0 & 827.3 & 828.6 & 829.8 \\
\hline 3.400 & 831.1 & 832.3 & 833.6 & 834.9 & 836.1 & 837.4 & 838.6 & 839.9 & 841.1 & 842.4 \\
\hline 3.500 & 843.6 & 844.9 & 846.1 & 847.4 & 848.6 & 849.9 & 851.1 & 852.3 & 853.6 & 854.8 \\
\hline 3.600 & 856.1 & 857.3 & 858.5 & 859.8 & 861.0 & 862.2 & 863.4 & 864.7 & 865.9 & 867.1 \\
\hline 3.700 & 868.3 & 869.5 & 870.8 & 872.0 & 873.2 & 874.4 & 875.6 & 876.8 & 878.0 & 879.2 \\
\hline $\mathbf{3 . 8 0 0}$ & 880.5 & 881.7 & 882.9 & 884.1 & 885.3 & 886.5 & 887.7 & 888.9 & 890.1 & 891.3 \\
\hline 3.900 & 892.5 & 893.6 & 894.8 & 896.0 & 897.2 & 898.4 & 899.6 & 900.8 & 902.0 & 903.1 \\
\hline
\end{tabular}


TABle 2A. Platinum-30 percent Rhodium versus Platinum-6 Percent Rhodium Thermocouples-Continued (Electromotive Force in Absolute Millivolts. Temperatures in Degrees C(Int. 1948). Reference Junctions at $0{ }^{\circ} \mathrm{C}$.)

\begin{tabular}{|c|c|c|c|c|c|c|c|c|c|c|}
\hline Millivolts & 0.000 & 0.010 & 0.020 & 0.030 & 0.040 & 0.050 & 0.060 & 0.070 & 0.080 & 0.090 \\
\hline \multirow[b]{2}{*}{4.000} & \multicolumn{10}{|c|}{ Degrees C } \\
\hline & 904.3 & 905.5 & 906.7 & 907.9 & 909.0 & 910.2 & 911.4 & 912.6 & 913.7 & 914.9 \\
\hline 4.100 & 916.1 & 917.2 & 918.4 & 919.6 & 920.7 & 921.9 & 923.1 & 924.2 & 925.4 & 926.5 \\
\hline 4.200 & 927.7 & 928.8 & 930.0 & 931.2 & 932.3 & 933.5 & 934.6 & 935.8 & 936.9 & 938.1 \\
\hline 4.300 & 939.2 & 940.3 & 941.5 & 942.6 & 943.8 & 944.9 & 946.1 & 947.2 & 948.3 & 949.5 \\
\hline 4.400 & 950.6 & 951.7 & 952.9 & 954.0 & 955.1 & 956.3 & 957.4 & 958.5 & 959.6 & 960.8 \\
\hline 4.500 & 961.9 & 963.0 & 964.1 & 965.3 & 966.4 & 967.5 & 968.6 & 969.7 & 970.9 & 972.0 \\
\hline 4.600 & 973.1 & 974.2 & 975.3 & 976.4 & 977.5 & 978.6 & 979.8 & 980.9 & 982.0 & 983.1 \\
\hline 4.700 & 984.2 & 985.3 & 986.4 & 987.5 & 988.6 & 989.7 & 990.8 & 991.9 & 993.0 & 994.1 \\
\hline 4.800 & 995.2 & 996.3 & 997.4 & 998.5 & 999.6 & 1000.6 & 1001.7 & 1002.8 & 1003.9 & 1005.0 \\
\hline 4.900 & 1006.1 & 1007.2 & 1008.3 & 1009.3 & 1010.4 & 1011.5 & 1012.6 & 1013.7 & 1014.8 & 1015.8 \\
\hline 5.000 & 1016.9 & 1018.0 & 1019.1 & 1020.1 & 1021.2 & 1022.3 & 1023.4 & 1024.4 & 1025.5 & 1026.6 \\
\hline 5.100 & 1027.6 & 1028.7 & 1029.8 & 1030.9 & 1031.9 & 1033.0 & 1034.1 & 1035.1 & 1036.2 & 1037.2 \\
\hline 5.200 & 1038.3 & 1039.4 & 1040.4 & 1041.5 & 1042.5 & 1043.6 & 1044.7 & 1045.7 & 1046.8 & 1047.8 \\
\hline 5.300 & 1048.9 & 1049.9 & 1051.0 & 1052.0 & 1053.1 & 1054.1 & 1055.2 & 1056.2 & 1057.3 & 1058.3 \\
\hline 5.400 & 1059.4 & 1060.4 & 1061.5 & 1062.5 & 1063.6 & 1064.6 & 1065.7 & 1066.7 & 1067.7 & 1068.8 \\
\hline 5.500 & 1069.8 & 1070.9 & 1071.9 & 1072.9 & 1074.0 & 1075.0 & 1076.0 & 1077.1 & 1078.1 & 1079.1 \\
\hline 5.600 & 1080.2 & 1081.2 & 1082.2 & 1083.3 & 1084.3 & 1085.3 & 1086.4 & 1087.4 & 1088.4 & 1089.4 \\
\hline 5.700 & 1090.5 & 1091.5 & 1092.5 & 1093.5 & 1094.6 & 1095.6 & 1096.6 & 1097.6 & 1098.7 & 1099.7 \\
\hline 5.800 & 1100.7 & 1101.7 & 1102.7 & 1103.8 & 1104.8 & 1105.8 & 1106.8 & 1107.8 & 1108.8 & 1109.9 \\
\hline 5.900 & 1110.9 & 1111.9 & 1112.9 & 1113.9 & 1114.9 & 1115.9 & 1116.9 & 1118.0 & 1119.0 & 1120.0 \\
\hline 6.000 & 1121.0 & 1122.0 & 1123.0 & 1124.0 & 1125.0 & 1126.0 & 1127.0 & 1128.0 & 1129.0 & 1130.0 \\
\hline 6.100 & 1131.0 & 1132.0 & 1133.0 & 1134.0 & 1135.0 & 1136.0 & 1137.0 & 1138.0 & 1139.0 & 1140.0 \\
\hline 6.200 & 1141.0 & 1142.0 & 1143.0 & 1144.0 & 1145.0 & 1146.0 & 1147.0 & 1148.0 & 1149.0 & 1150.0 \\
\hline 6.300 & 1151.0 & 1152.0 & 1153.0 & 1154.0 & 1155.0 & 1155.9 & 1156.9 & 1157.9 & 1158.9 & 1159.9 \\
\hline 6.400 & 1160.9 & 1161.9 & 1162.9 & 1163.8 & 1164.8 & 1165.8 & 1166.8 & 1167.8 & 1168.8 & 1169.8 \\
\hline 6.500 & 1170.7 & 1171.7 & 1172.7 & 1173.7 & 1174.7 & 1175.6 & 1176.6 & 1177.6 & 1178.6 & 1179.6 \\
\hline 6.600 & 1180.5 & 1181.5 & 1182.5 & 1183.5 & 1184.4 & 1185.4 & 1186.4 & 1187.4 & 1188.3 & 1189.3 \\
\hline 6.700 & 1190.3 & 1191.3 & 1192.2 & 1193.2 & 1194.2 & 1195.1 & 1196.1 & 1197.1 & 1198.0 & 1199.0 \\
\hline 6.800 & 1200.0 & 1200.9 & 1201.9 & 1202.9 & 1203.8 & 1204.8 & 1205.8 & 1206.7 & 1207.7 & 1208.6 \\
\hline 6.900 & 1209.6 & 1210.6 & 1211.5 & 1212.5 & 1213.4 & 1214.4 & 1215.3 & 1216.3 & 1217.2 & 1218.2 \\
\hline 7.000 & 1219.2 & 1220.1 & 1221.1 & 1222.0 & 1223.0 & 1223.9 & 1224.9 & 1225.8 & 1226.8 & 1227.7 \\
\hline 7.100 & 1228.7 & 1229.6 & 1230.6 & 1231.5 & 1232.5 & 1233.4 & 1234.4 & 1235.3 & 1236.2 & 1237.2 \\
\hline 7.200 & 1238.1 & 1239.1 & 1240.0 & 1241.0 & 1241.9 & 1242.8 & 1243.8 & 1244.7 & 1245.7 & 1246.6 \\
\hline 7.300 & 1247.5 & 1248.5 & 1249.4 & 1250.4 & 1251.3 & 1252.2 & 1253.2 & 1254.1 & 1255.0 & 1256.0 \\
\hline 7.400 & 1256.9 & 1257.8 & 1258.8 & 1259.7 & 1260.6 & 1261.6 & 1262.5 & 1263.4 & 1264.4 & 1265.3 \\
\hline 7.500 & 1266.2 & 1267.2 & 1268.1 & 1269.0 & 1269.9 & 1270.9 & 1271.8 & 1272.7 & 1273.7 & 1274.6 \\
\hline 7.600 & 1275.5 & 1276.4 & 1277.4 & 1278.3 & 1279.2 & 1280.1 & 1281.1 & 1282.0 & 1282.9 & 1283.8 \\
\hline 7.700 & 1284.7 & 1285.7 & 1286.6 & 1287.5 & 1288.4 & 1289.3 & 1290.3 & 1291.2 & 1292.1 & 1293.0 \\
\hline 7.800 & 1293.9 & 1294.9 & 1295.8 & 1296.7 & 1297.6 & 1298.5 & 1299.4 & 1300.4 & 1301.3 & 1302.2 \\
\hline 7.900 & 1303.1 & 1304.0 & 1304.9 & 1305.8 & 1306.8 & 1307.7 & 1308.6 & 1309.5 & 1310.4 & 1311.3 \\
\hline
\end{tabular}


Table 2A. Platinum-30 percent Rhodium versus Platinum-6 Percent Rhodium Thermocouples-Continued (Electromotive Force in Absolute Millivolts. Temperatures in Degrees C(Int. 1948). Reference Junctions at $0{ }^{\circ} \mathrm{C}$.)

\begin{tabular}{|c|c|c|c|c|c|c|c|c|c|c|}
\hline Millivolts & 0.000 & 0.010 & 0.020 & 0.030 & 0.040 & 0.050 & 0.060 & 0.070 & 0.080 & 0.090 \\
\hline \multirow[b]{2}{*}{8.000} & \multicolumn{10}{|c|}{ Degrees C } \\
\hline & 1312.2 & 1313.1 & 1314.0 & 1315.0 & 1315.9 & 1316.8 & 1317.7 & 1318.6 & 1319.5 & 1320.4 \\
\hline 8.100 & 1321.3 & 1322.2 & 1323.1 & 1324.0 & 1324.9 & 1325.8 & 1326.7 & 1327.7 & 1328.6 & 1329.5 \\
\hline 8.200 & 1330.4 & 1331.3 & 1332.2 & 1333.1 & 1334.0 & 1334.9 & 1335.8 & 1336.7 & 1337.6 & 1338.5 \\
\hline 8.300 & 1339.4 & 1340.3 & 1341.2 & 1342.1 & 134.3 .0 & 1343.9 & 1344.8 & 1345.7 & 1346.6 & 1347.5 \\
\hline 8.400 & 1348.4 & 1349.3 & 1350.2 & 1351.1 & 1352.0 & 1352.9 & 1353.8 & 1354.7 & 1355.6 & 1356.5 \\
\hline 8.500 & 1357.4 & 1358.3 & 1359.1 & 1360.0 & 1360.9 & 1361.8 & 1362.7 & 1363.6 & 1364.5 & 1365.4 \\
\hline 8.600 & 1366.3 & 1367.2 & 1368.1 & 1369.0 & 1369.9 & 1370.8 & 1371.7 & 1372.5 & 1373.4 & 1374.3 \\
\hline 8.700 & 1375.2 & 1376.1 & 1377.0 & 1377.9 & 1378.8 & 1379.7 & 1380.6 & 1381.4 & 1382.3 & 1383.2 \\
\hline 8.800 & 1384.1 & 1385.0 & 1385.9 & 1386.8 & 1387.7 & 1388.5 & 1389.4 & 1390.3 & 1391.2 & 1392.1 \\
\hline 8.900 & 1393.0 & 1393.9 & 1394.7 & 1395.6 & 1396.5 & 1397.4 & 1398.3 & 1399.2 & 1400.0 & 1400.9 \\
\hline 9.000 & 1401.8 & 1402.7 & 1403.6 & 1404.5 & 1405.3 & 1406.2 & 1407.1 & 1408.0 & 1408.9 & 1409.8 \\
\hline 9.100 & 1410.6 & 1411.5 & 1412.4 & 1413.3 & 1414.2 & 1415.0 & 1415.9 & 1416.8 & 1417.7 & 1418.6 \\
\hline 9.200 & 1419.4 & 1420.3 & 1421.2 & 1422.1 & 1423.0 & 1423.8 & 1424.7 & 1425.6 & 1426.5 & 1427.3 \\
\hline 9.300 & 1428.2 & 1429.1 & 1430.0 & 1430.9 & 1431.7 & 1432.6 & 1433.5 & 1434.4 & 1435.2 & 1436.1 \\
\hline 9.400 & 1437.0 & 1437.9 & 1438.7 & 1439.6 & 1440.5 & 1441.4 & 1442.2 & 1443.1 & 1444.0 & 1444.9 \\
\hline 9.500 & 1445.7 & 1446.6 & 1447.5 & 1448.4 & 1449.2 & 1450.1 & 1451.0 & 1451.9 & 1452.7 & 1453.6 \\
\hline 9.600 & 1454.5 & 1455.3 & 1456.2 & 1457.1 & 1458.0 & 1458.8 & 1459.7 & 1460.6 & 1461.4 & 1462.3 \\
\hline 9.700 & 1463.2 & 1464.1 & 1464.9 & 1465.8 & 1466.7 & 1467.5 & 1468.4 & 1469.3 & 1470.1 & 1471.0 \\
\hline 9.800 & 1471.9 & 1472.8 & 1473.6 & 1474.5 & 1475.4 & 1476.2 & 1477.1 & 1478.0 & 1478.8 & 1479.7 \\
\hline 9.900 & 1480.6 & 1481.4 & 1482.3 & 1483.2 & 1484.0 & 1484.9 & 1485.8 & 1486.6 & 1487.5 & 1488.4 \\
\hline 10.000 & 1489.3 & 1490.1 & 1491.0 & 1491.9 & 1492.7 & 1493.6 & 1494.4 & 1495.3 & 1496.2 & 1497.0 \\
\hline 10.100 & 1497.9 & 1498.8 & 1499.6 & 1500.5 & 1501.4 & 1502.2 & 1503.1 & 1504.0 & 1504.8 & 1505.7 \\
\hline 10.200 & 1506.6 & 1507.4 & 1508.3 & 1509.2 & 1510.0 & 1510.9 & 1511.8 & 1512.6 & 1513.5 & 1514.3 \\
\hline 10.300 & 1515.2 & 1516.1 & 1516.9 & 1517.8 & 1518.7 & 1519.5 & 1520.4 & 1521.3 & 1522.1 & 1523.0 \\
\hline 10.400 & 1523.8 & 1524.7 & 1525.6 & 1526.4 & 1527.3 & 1528.2 & 1529.0 & 1529.9 & 1530.7 & 1531.6 \\
\hline $\mathbf{1 0 . 5 0 0}$ & 1532.5 & 1533.3 & 1534.2 & 1535.0 & 1535.9 & 1536.8 & 1537.6 & 1538.5 & 1539.4 & 1540.2 \\
\hline 10.600 & 1541.1 & 1541.9 & 1542.8 & 1543.7 & 1544.5 & 1545.4 & 1546.2 & 1547.1 & 1548.0 & 1548.8 \\
\hline 10.700 & 1549.7 & 1550.5 & 1551.4 & 1552.3 & 1553.1 & 1554.0 & 1554.8 & 1555.7 & 1556.6 & 1557.4 \\
\hline 10.800 & 1558.3 & 1559.1 & 1560.0 & 1560,9 & 1561.7 & 1562.6 & 1563.4 & 1564.3 & 1565.2 & 1566.0 \\
\hline 10.900 & 1566.9 & 1567.7 & 1568.6 & 1569.5 & 1570.3 & 1571.2 & 1572.0 & 1572.9 & 1573.8 & 1574.6 \\
\hline 11.000 & 1575.5 & 1576.3 & 1577.2 & 1578.0 & 1578.9 & 1579.8 & 1580.6 & 1581.5 & 1582.3 & 1583.2 \\
\hline 11.100 & 1584.1 & 1584.9 & 1585.8 & 1586.6 & 1587.5 & 1588.3 & 1589.2 & 1590.1 & 1590.9 & 1591.8 \\
\hline 11.200 & 1592.6 & 1593.5 & 1594.3 & 1595.2 & 1596.1 & 1596.9 & 1597.8 & 1598.6 & 1599.5 & 1600.3 \\
\hline 11.300 & 1601.2 & 1602.1 & 1602.9 & 1603.8 & 1604.6 & 1605.5 & 1606.3 & 1607.2 & 1608.1 & 1608.9 \\
\hline 11.400 & 1609.8 & 1610.6 & 1611.5 & 1612.3 & 1613.2 & 1614.1 & 1614.9 & 1615.8 & 1616.6 & 1617.5 \\
\hline 11.500 & 1618.3 & 1619.2 & 1620.1 & 1620.9 & 1621.8 & 1622.6 & 1623.5 & 1624.3 & 1625.2 & 1626.1 \\
\hline 11.600 & 1626.9 & 1627.8 & 1628.6 & 1629.5 & 1630.3 & 1631.2 & 1632.1 & 1632.9 & 1633.8 & 1634.6 \\
\hline 11.700 & 1635.5 & 1636.3 & 1637.2 & 1638.1 & 1638.9 & 1639.8 & 1640.6 & 1641.5 & 1642.3 & 1643.2 \\
\hline 11.800 & 1644.0 & 1644.9 & 1645.8 & 1646.6 & 1647.5 & 1648.3 & 1649.2 & 1650.0 & 1650.9 & 1651.8 \\
\hline 11.900 & 1652.6 & 1653.5 & 1654.3 & 1655.2 & 1656.0 & 1656.9 & 1657.8 & 1658.6 & 1659.5 & 1660.3 \\
\hline
\end{tabular}


Table 2A. Platinum-30 percent Rhodium versus Platinum-6 Percent Rhodium Thermocouples-Continued (Electromotive Force in Absolute Millivolts. Temperatures in Degrees C(Int. 1948). Reference Junctions at $0{ }^{\circ} \mathrm{C}$.)

\begin{tabular}{|c|c|c|c|c|c|c|c|c|c|c|}
\hline Millivolts & 0.000 & 0.010 & 0.020 & 0.030 & 0.040 & 0.050 & 0.060 & 0.070 & 0.080 & 0.090 \\
\hline & \multicolumn{10}{|c|}{ Degrees C } \\
\hline 12.000 & 1661.2 & 1662.0 & 1662.9 & 1663.7 & 1664.6 & 1665.5 & 1666.3 & 1667.2 & 1668.0 & 1668.9 \\
\hline $\begin{array}{l}12.100 \\
12.200 \\
12.300\end{array}$ & $\begin{array}{l}1669.7 \\
1678.3 \\
1686.9\end{array}$ & $\begin{array}{l}1670.6 \\
1679.2 \\
1687.7\end{array}$ & $\begin{array}{l}1671.5 \\
1680.0 \\
1688.6\end{array}$ & $\begin{array}{l}1672.3 \\
1680.9 \\
1689.5\end{array}$ & $\begin{array}{l}1673.2 \\
1681.7 \\
1690.3\end{array}$ & $\begin{array}{l}1674.0 \\
1682.6 \\
1691.2\end{array}$ & $\begin{array}{l}1674.9 \\
1683.5 \\
1692.0\end{array}$ & $\begin{array}{l}1675.7 \\
1684.3 \\
1692.9\end{array}$ & $\begin{array}{l}1676.6 \\
1685.2 \\
1693.7\end{array}$ & $\begin{array}{l}1677.5 \\
1686.0 \\
1694.6\end{array}$ \\
\hline $\begin{array}{l}12.400 \\
12.500 \\
12.600\end{array}$ & $\begin{array}{l}1695.5 \\
1704.0 \\
1712.6\end{array}$ & $\begin{array}{l}1696.3 \\
1704.9 \\
1713.5\end{array}$ & $\begin{array}{l}1697.2 \\
1705.7 \\
1714.3\end{array}$ & $\begin{array}{l}1698.0 \\
1706.6 \\
1715.2\end{array}$ & $\begin{array}{l}1698.9 \\
1707.5 \\
1716.0\end{array}$ & $\begin{array}{l}1699.7 \\
1708.3 \\
1716.9\end{array}$ & $\begin{array}{l}1700.6 \\
1709.2 \\
1717.8\end{array}$ & $\begin{array}{l}1701.5 \\
1710.0 \\
1718.6\end{array}$ & $\begin{array}{l}1702.3 \\
1710.9 \\
1719.5\end{array}$ & $\begin{array}{l}1703.2 \\
1711.7 \\
1720.3\end{array}$ \\
\hline $\begin{array}{l}12.700 \\
12.800 \\
12.900\end{array}$ & $\begin{array}{l}1721.2 \\
1729.8 \\
1738.4\end{array}$ & $\begin{array}{l}1722.0 \\
1730.6 \\
1739.2\end{array}$ & $\begin{array}{l}1722.9 \\
1731.5 \\
1740.1\end{array}$ & $\begin{array}{l}1723.8 \\
1732.3 \\
1740.9\end{array}$ & $\begin{array}{l}1724.6 \\
1733.2 \\
1741.8\end{array}$ & $\begin{array}{l}1725.5 \\
1734.1 \\
1742.7\end{array}$ & $\begin{array}{l}1726.3 \\
1734.9 \\
1743.5\end{array}$ & $\begin{array}{l}1727.2 \\
1735.8 \\
1744.4\end{array}$ & $\begin{array}{l}1728.1 \\
1736.6 \\
1745.2\end{array}$ & $\begin{array}{l}1728.9 \\
1737.5 \\
1746.1\end{array}$ \\
\hline 13.000 & 1747.0 & 1747.8 & 1748.7 & 1749.5 & 1750.4 & 1751.3 & 1752.1 & 1753.0 & 1753.8 & 1754.7 \\
\hline $\begin{array}{l}13.100 \\
13.200 \\
13.300\end{array}$ & $\begin{array}{l}1755.6 \\
1764.2 \\
1772.8\end{array}$ & $\begin{array}{l}1756.4 \\
1765.0 \\
1773.6\end{array}$ & $\begin{array}{l}1757.3 \\
1765.9 \\
1774.5\end{array}$ & $\begin{array}{l}1758.1 \\
1766.7 \\
1775.4\end{array}$ & $\begin{array}{l}1759.0 \\
1767.6 \\
1776.2\end{array}$ & $\begin{array}{l}1759.9 \\
1768.5 \\
1777.1\end{array}$ & $\begin{array}{l}1760.7 \\
1769.3 \\
1778.0\end{array}$ & $\begin{array}{l}1761.6 \\
1770.2 \\
1778.8\end{array}$ & $\begin{array}{l}1762.4 \\
1771.1 \\
1779.7\end{array}$ & $\begin{array}{l}1763.3 \\
1771.9 \\
1780.5\end{array}$ \\
\hline $\begin{array}{l}13.400 \\
13.500 \\
13.600\end{array}$ & $\begin{array}{l}1781.4 \\
1790.0 \\
1798.7\end{array}$ & $\begin{array}{l}1782.3 \\
1790.9 \\
1799.5\end{array}$ & $\begin{array}{l}1783.1 \\
1791.8 \\
1800.4\end{array}$ & $\begin{array}{l}1784.0 \\
1792.6 \\
1801.3\end{array}$ & $\begin{array}{l}1784.8 \\
1793.5 \\
1802.1\end{array}$ & $\begin{array}{l}1785.7 \\
1794.3 \\
1803.0\end{array}$ & $\begin{array}{l}1786.6 \\
1795.2 \\
1803.8\end{array}$ & $\begin{array}{l}1787.4 \\
1796.1 \\
1804.7\end{array}$ & $\begin{array}{l}1788.3 \\
1796.9 \\
1805.6\end{array}$ & $\begin{array}{l}1789.2 \\
1797.8 \\
1806.4\end{array}$ \\
\hline $\begin{array}{l}13.700 \\
13.800\end{array}$ & $\begin{array}{l}1807.3 \\
1816.0\end{array}$ & $\begin{array}{l}1808.2 \\
1816.8\end{array}$ & $\begin{array}{l}1809.0 \\
1817.7\end{array}$ & $\begin{array}{l}1809.9 \\
1818.6\end{array}$ & $\begin{array}{l}1810.8 \\
1819.4\end{array}$ & 1811.6 & 1812.5 & 1813.4 & 1814.2 & 1815.1 \\
\hline
\end{tabular}


Table 3A Platinum-30 percent Rhodium versus Platinum-6 Percent Rhodium Thermocouples

(Temperatures in Degrees F. Electromotive Force in Absolute Millivolts. Reference Junctions at $32^{\circ} \mathrm{F}$.)

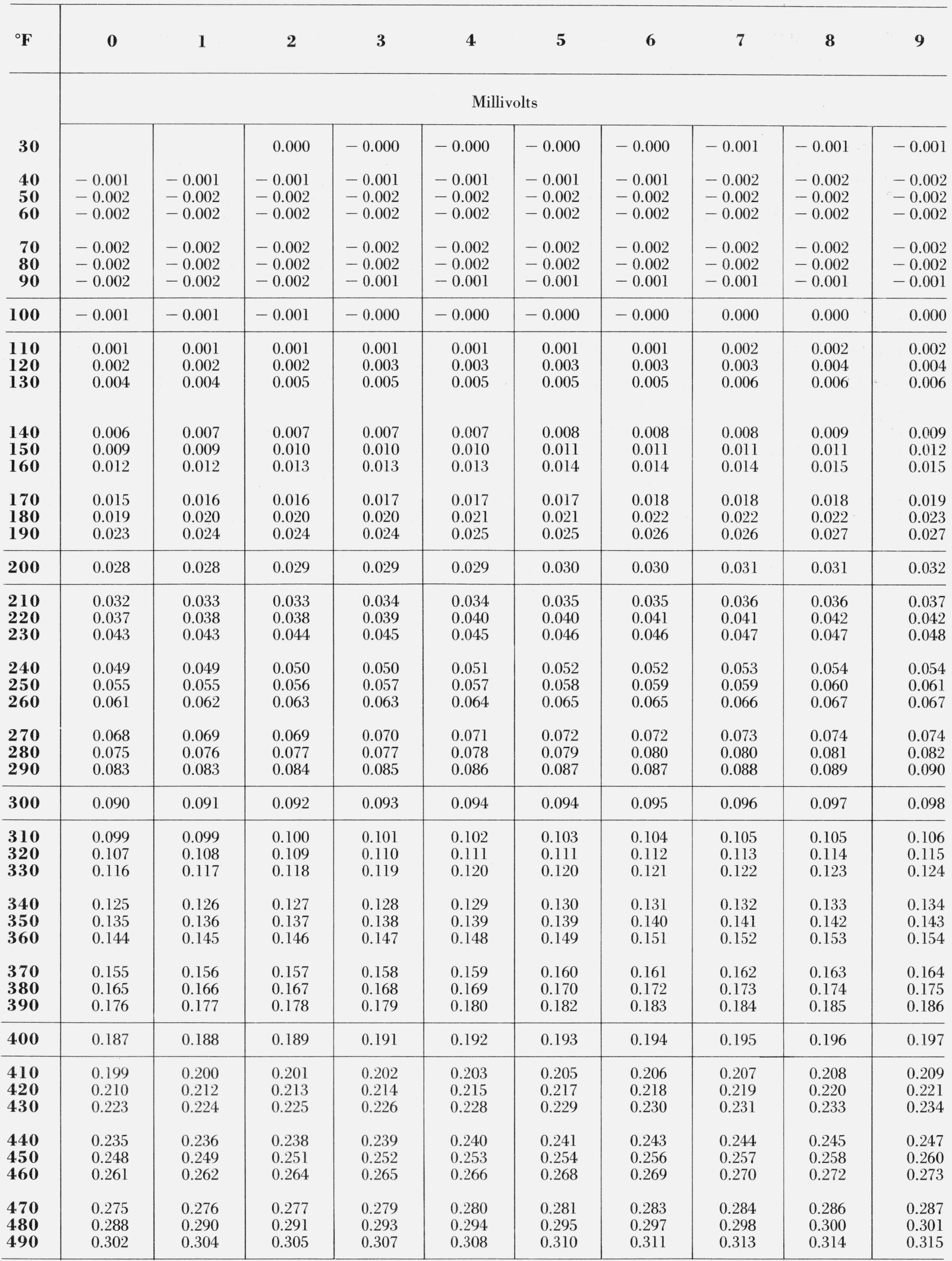


TABle 3A Platinum-30 percent Rhodium versus Platinum-6 Percent Rhodium Thermocouples-Continued (Temperatures in Degrees F. Electromotive Force in Absolute Millivolts. Reference Junctions at $32{ }^{\circ} \mathrm{F}$.)

\begin{tabular}{|c|c|c|c|c|c|c|c|c|c|c|}
\hline \multirow{2}{*}{${ }^{\circ} \mathbf{F}$} & 0 & 1 & 2 & 3 & 4 & 5 & 6 & 7 & 8 & 9 \\
\hline & \multicolumn{10}{|c|}{ Millivolts } \\
\hline 500 & 0.317 & 0.318 & 0.320 & 0.321 & 0.323 & 0.324 & 0.326 & 0.327 & 0.329 & 0.330 \\
\hline \multirow{3}{*}{$\begin{array}{l}510 \\
520 \\
530\end{array}$} & 0.332 & 0.333 & 0.335 & 0.336 & 0.338 & 0.339 & 0.341 & 0.342 & 0.344 & 0.345 \\
\hline & 0.347 & 0.348 & 0.350 & 0.351 & 0.353 & 0.354 & 0.356 & 0.358 & 0.359 & 0.361 \\
\hline & 0.362 & 0.364 & 0.365 & 0.367 & 0.368 & 0.370 & 0.372 & 0.373 & 0.375 & 0.376 \\
\hline \multirow{3}{*}{$\begin{array}{l}\mathbf{5 4 0} \\
\mathbf{5 5 0} \\
\mathbf{5 6 0}\end{array}$} & 0.378 & 0.380 & 0.381 & 0.383 & 0.384 & 0.386 & 0.388 & 0.389 & 0.391 & 0.392 \\
\hline & 0.394 & 0.396 & 0.397 & 0.399 & 0.401 & 0.402 & 0.404 & 0.405 & 0.407 & 0.409 \\
\hline & 0.410 & 0.412 & 0.414 & 0.415 & 0.417 & 0.419 & 0.420 & 0.422 & 0.424 & 0.425 \\
\hline \multirow{3}{*}{$\begin{array}{l}570 \\
580 \\
590\end{array}$} & 0.427 & 0.429 & 0.431 & 0.432 & 0.434 & 0.436 & 0.437 & 0.439 & 0.441 & 0.442 \\
\hline & 0.444 & 0.446 & 0.448 & 0.449 & 0.451 & 0.453 & 0.455 & 0.456 & 0.458 & 0.460 \\
\hline & 0.462 & 0.463 & 0.465 & 0.467 & 0.469 & 0.470 & 0.472 & 0.474 & 0.476 & 0.477 \\
\hline 600 & 0.479 & 0.481 & 0.483 & 0.485 & 0.486 & 0.488 & 0.490 & 0.492 & 0.494 & 0.495 \\
\hline \multirow{3}{*}{$\begin{array}{l}610 \\
620 \\
630\end{array}$} & 0.497 & 0.499 & 0.501 & 0.503 & 0.504 & 0.506 & 0.508 & 0.510 & 0.512 & 0.514 \\
\hline & 0.515 & 0.517 & 0.519 & 0.521 & 0.523 & 0.525 & 0.527 & 0.528 & 0.530 & 0.532 \\
\hline & 0.534 & 0.536 & 0.538 & 0.540 & 0.542 & 0.543 & 0.545 & 0.547 & 0.549 & 0.551 \\
\hline \multirow{3}{*}{$\begin{array}{l}640 \\
650 \\
660\end{array}$} & 0.553 & 0.555 & 0.557 & 0.559 & 0.561 & 0.563 & 0.564 & 0.566 & 0.568 & 0.570 \\
\hline & 0.572 & 0.574 & 0.576 & 0.578 & 0.580 & 0.582 & 0.584 & 0.586 & 0.588 & 0.590 \\
\hline & 0.592 & 0.594 & 0.596 & 0.598 & 0.600 & 0.602 & 0.604 & 0.606 & 0.608 & 0.610 \\
\hline \multirow{3}{*}{$\begin{array}{l}670 \\
680 \\
690\end{array}$} & 0.612 & 0.614 & 0.616 & 0.618 & 0.620 & 0.622 & 0.624 & 0.626 & 0.628 & 0.630 \\
\hline & 0.632 & 0.634 & 0.636 & 0.638 & 0.640 & 0.642 & 0.644 & 0.646 & 0.648 & 0.650 \\
\hline & 0.652 & 0.654 & 0.656 & 0.659 & 0.661 & 0.663 & 0.665 & 0.667 & 0.669 & 0.671 \\
\hline 700 & 0.673 & 0.675 & 0.677 & 0.679 & 0.682 & 0.684 & 0.686 & 0.688 & 0.690 & 0.692 \\
\hline \multirow{3}{*}{$\begin{array}{l}710 \\
720 \\
730\end{array}$} & 0.694 & 0.696 & 0.698 & 0.701 & 0.703 & 0.705 & 0.707 & 0.709 & 0.711 & 0.714 \\
\hline & 0.716 & 0.718 & 0.720 & 0.722 & 0.724 & 0.726 & 0.729 & 0.731 & 0.733 & 0.735 \\
\hline & 0.737 & 0.740 & 0.742 & 0.744 & 0.746 & 0.748 & 0.751 & 0.753 & 0.755 & 0.757 \\
\hline \multirow{3}{*}{$\begin{array}{l}740 \\
750 \\
760\end{array}$} & 0.759 & 0.762 & 0.764 & 0.766 & 0.768 & 0.771 & 0.773 & 0.755 & 0.777 & 0.780 \\
\hline & 0.782 & 0.784 & 0.786 & 0.789 & 0.791 & 0.793 & 0.795 & 0.798 & 0.800 & 0.802 \\
\hline & 0.804 & 0.807 & 0.809 & 0.811 & 0.814 & 0.816 & 0.818 & 0.820 & 0.823 & 0.825 \\
\hline \multirow{3}{*}{$\begin{array}{l}770 \\
780 \\
790\end{array}$} & 0.827 & 0.830 & 0.832 & 0.834 & 0.837 & 0.839 & 0.841 & 0.844 & 0.846 & 0.848 \\
\hline & 0.851 & 0.853 & 0.855 & 0.858 & 0.860 & 0.862 & 0.865 & 0.867 & 0.869 & 0.872 \\
\hline & 0.874 & 0.877 & 0.879 & 0.881 & 0.884 & 0.886 & 0.888 & 0.891 & 0.893 & 0.896 \\
\hline 800 & 0.898 & 0.900 & 0.903 & 0.905 & 0.908 & 0.910 & 0.913 & 0.915 & 0.917 & 0.920 \\
\hline \multirow{3}{*}{$\begin{array}{l}810 \\
820 \\
830\end{array}$} & 0.922 & 0.925 & 0.927 & 0.930 & 0.932 & 0.934 & 0.937 & 0.939 & 0.942 & 0.944 \\
\hline & 0.947 & 0.949 & 0.952 & 0.954 & 0.957 & 0.959 & 0.962 & 0.964 & 0.967 & 0.969 \\
\hline & 0.972 & 0.974 & 0.976 & 0.979 & 0.982 & 0.984 & 0.987 & 0.989 & 0.992 & 0.994 \\
\hline \multirow{3}{*}{$\begin{array}{l}840 \\
850 \\
860\end{array}$} & 0.997 & 0.999 & 1.002 & 1.004 & 1.007 & 1.009 & 1.012 & 1.014 & 1.017 & 1.019 \\
\hline & 1.022 & 1.025 & 1.027 & 1.030 & 1.032 & 1.035 & 1.037 & 1.040 & 1.042 & 1.045 \\
\hline & 1.048 & 1.050 & 1.053 & 1.055 & 1.058 & 1.061 & 1.063 & 1.066 & 1.068 & 1.071 \\
\hline \multirow{3}{*}{$\begin{array}{l}870 \\
880 \\
890\end{array}$} & 1.074 & 1.076 & 1.079 & 1.081 & 1.084 & 1.087 & 1.089 & 1.092 & 1.095 & 1.097 \\
\hline & 1.100 & 1.103 & 1.105 & 1.108 & 1.110 & 1.113 & 1.116 & 1.118 & 1.121 & 1.124 \\
\hline & 1.126 & 1.129 & 1.132 & 1.134 & 1.137 & 1.140 & 1.143 & 1.145 & 1.148 & 1.151 \\
\hline
\end{tabular}


TABle 3A Platinum-30 percent Rhodium versus Platinum-6 Percent Rhodium Thermocouples-Continued (Temperatures in Degrees F. Electromotive Force in Absolute Millivolts. Reference Junctions at $32^{\circ} \mathrm{F}$.)

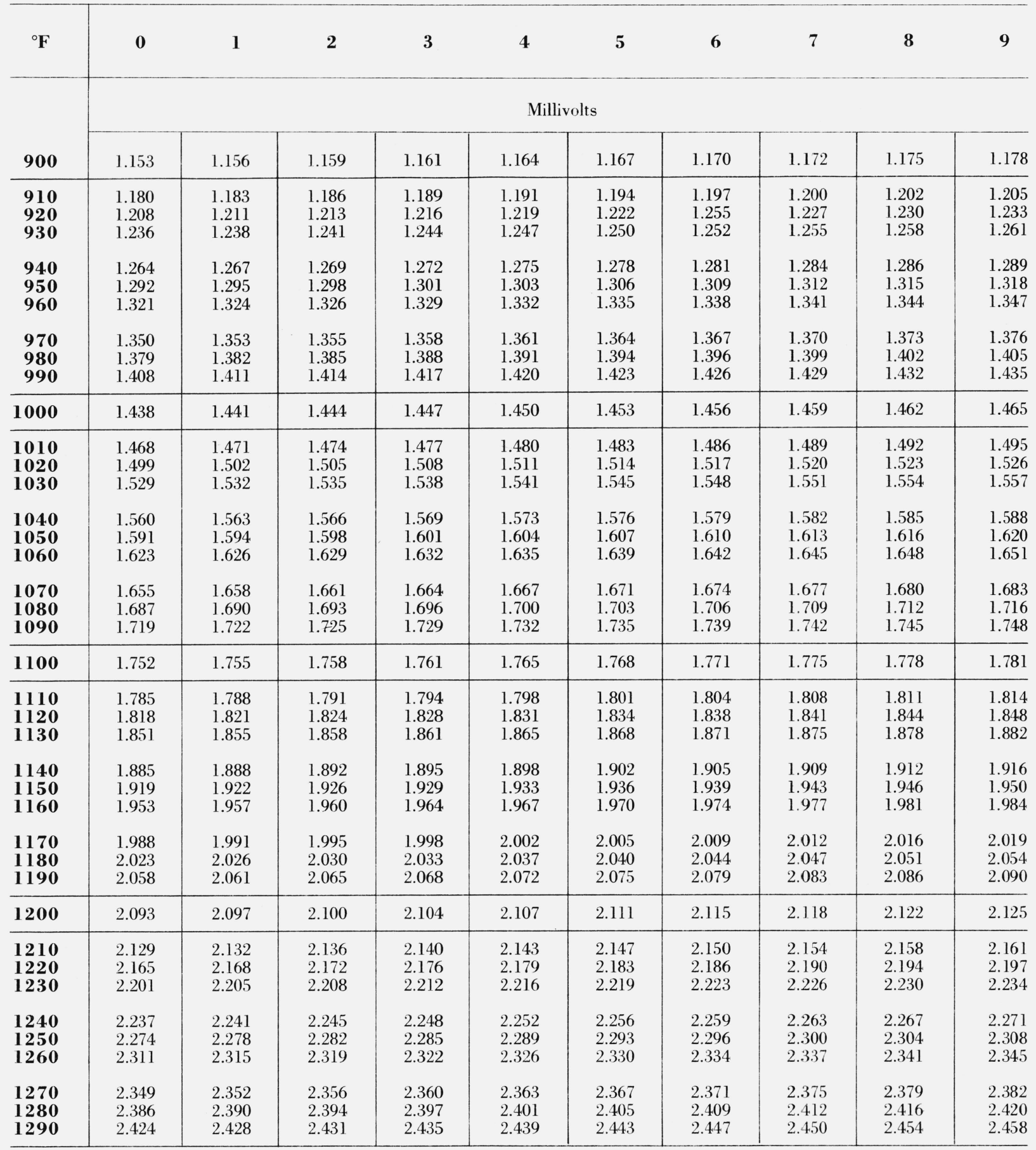


TABle 3A Platinum-30 percent Rhodium versus Platinum-6 Percent Rhodium Thermocouples-Continued

(Temperatures in Degrees F. Electromotive Force in Absolute Millivolts. Reference Junctions at $32{ }^{\circ} \mathrm{F}$.)

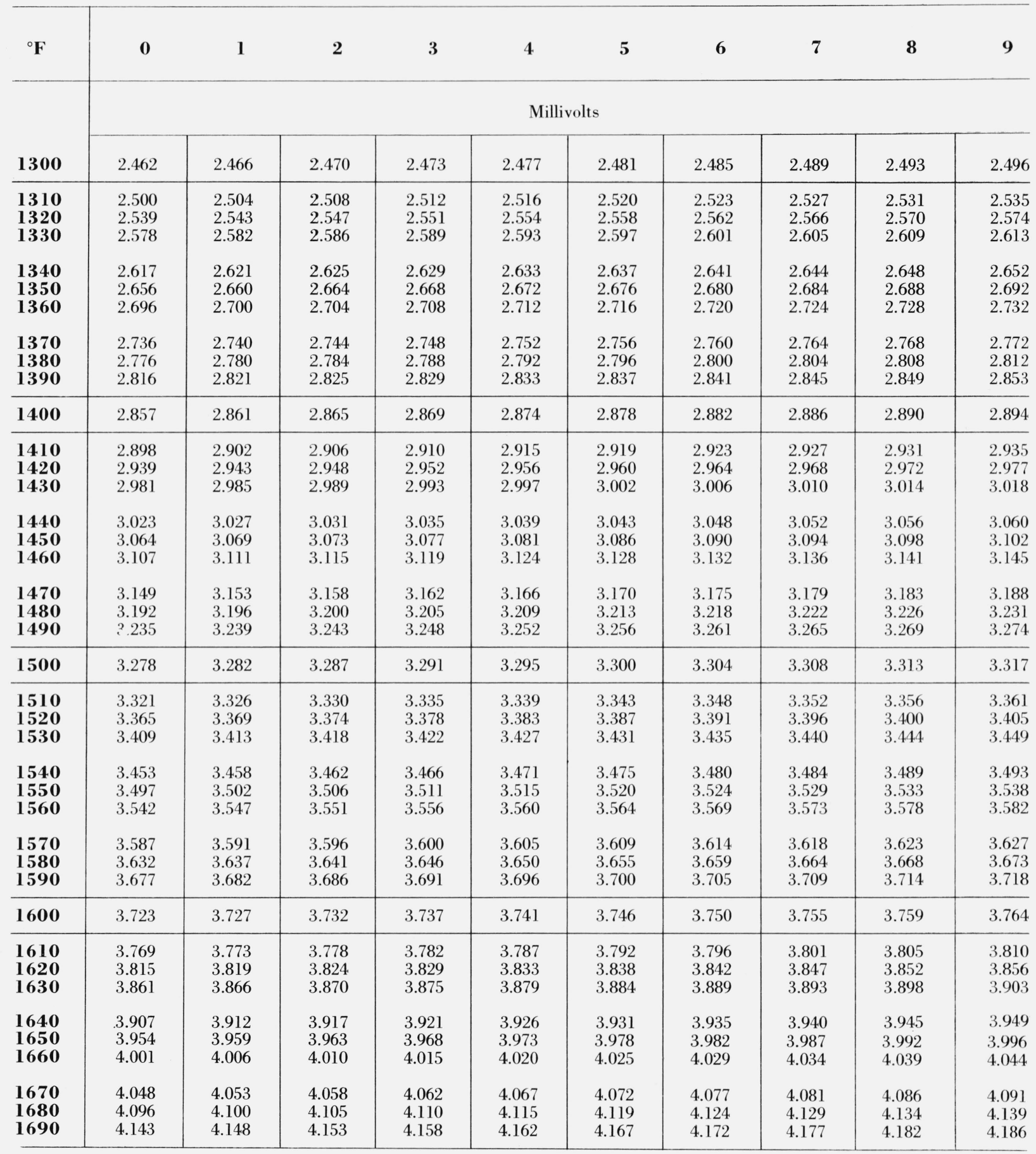


TABle 3A Platinum-30 percent Rhodium versus Platinum-6 Percent Rhodium Thermocouples-Continued (Temperatures in Degrees F. Electromotive Force in Absolute Millivolts. Reference Junctions at $32{ }^{\circ} \mathrm{F}$.)

\begin{tabular}{|c|c|c|c|c|c|c|c|c|c|c|}
\hline \multirow[b]{2}{*}{1700} & 0 & 1 & 2 & 3 & 4 & 5 & 6 & 7 & 8 & 9 \\
\hline & 4.191 & 4.196 & 4.201 & 4.206 & 4.210 & 4.215 & 4.220 & 4.225 & 4.230 & 4.234 \\
\hline $\begin{array}{l}1740 \\
1750 \\
1760\end{array}$ & $\begin{array}{l}4.385 \\
4.434 \\
4.483\end{array}$ & $\begin{array}{l}4.390 \\
4.439 \\
4.488\end{array}$ & $\begin{array}{l}4.395 \\
4.444 \\
4.493\end{array}$ & $\begin{array}{l}4.400 \\
4.449 \\
4.498\end{array}$ & $\begin{array}{l}4.404 \\
4.454 \\
4.503\end{array}$ & $\begin{array}{l}4.409 \\
4.458 \\
4.508\end{array}$ & $\begin{array}{l}4.414 \\
4.463 \\
4.513\end{array}$ & $\begin{array}{l}4.419 \\
4.468 \\
4.518\end{array}$ & $\begin{array}{l}4.424 \\
4.473 \\
4.523\end{array}$ & $\begin{array}{l}4.429 \\
4.478 \\
4.528\end{array}$ \\
\hline $\begin{array}{l}1770 \\
1780 \\
1790\end{array}$ & $\begin{array}{l}4.533 \\
4.582 \\
4.632\end{array}$ & $\begin{array}{l}4.538 \\
4.587 \\
4.637\end{array}$ & $\begin{array}{l}4.543 \\
4.592 \\
4.642\end{array}$ & $\begin{array}{l}4.547 \\
4.597 \\
4.647\end{array}$ & $\begin{array}{l}4.552 \\
4.602 \\
4.652\end{array}$ & $\begin{array}{l}4.557 \\
4.607 \\
4.657\end{array}$ & $\begin{array}{l}4.562 \\
4.612 \\
4.662\end{array}$ & $\begin{array}{l}4.567 \\
4.617 \\
4.667\end{array}$ & $\begin{array}{l}4.572 \\
4.622 \\
4.672\end{array}$ & $\begin{array}{l}4.577 \\
4.627 \\
4.677\end{array}$ \\
\hline $\begin{array}{l}1810 \\
1820 \\
1830\end{array}$ & $\begin{array}{l}4.733 \\
4.783 \\
4.834\end{array}$ & $\begin{array}{l}4.738 \\
4.788 \\
4.839\end{array}$ & $\begin{array}{l}4.743 \\
4.793 \\
4.844\end{array}$ & $\begin{array}{l}4.748 \\
4.798 \\
4.849\end{array}$ & $\begin{array}{l}4.753 \\
4.803 \\
4.854\end{array}$ & $\begin{array}{l}4.758 \\
4.808 \\
4.859\end{array}$ & $\begin{array}{l}4.763 \\
4.814 \\
4.864\end{array}$ & $\begin{array}{l}4.768 \\
4.819 \\
4.870\end{array}$ & $\begin{array}{l}4.773 \\
4.824 \\
4.875\end{array}$ & $\begin{array}{l}4.778 \\
4.829 \\
4.880\end{array}$ \\
\hline $\begin{array}{l}1840 \\
1850 \\
1860\end{array}$ & $\begin{array}{l}4.885 \\
4.936 \\
4.987\end{array}$ & $\begin{array}{l}4.890 \\
4.941 \\
4.993\end{array}$ & $\begin{array}{l}4.895 \\
4.946 \\
4.998\end{array}$ & $\begin{array}{l}4.900 \\
4.951 \\
5.003\end{array}$ & $\begin{array}{l}4.905 \\
4.957 \\
5.008\end{array}$ & $\begin{array}{l}4.910 \\
4.962 \\
5.013\end{array}$ & $\begin{array}{l}4.916 \\
4.967 \\
5.018\end{array}$ & $\begin{array}{l}4.921 \\
4.972 \\
5.024\end{array}$ & $\begin{array}{l}4.926 \\
4.977 \\
5.029\end{array}$ & $\begin{array}{l}4.931 \\
4.982 \\
5.034\end{array}$ \\
\hline $\begin{array}{l}1870 \\
1880 \\
1890\end{array}$ & $\begin{array}{l}5.039 \\
5.091 \\
5.143\end{array}$ & $\begin{array}{l}5.044 \\
5.096 \\
5.148\end{array}$ & $\begin{array}{l}5.049 \\
5.101 \\
5.153\end{array}$ & $\begin{array}{l}5.055 \\
5.106 \\
5.158\end{array}$ & $\begin{array}{l}5.060 \\
5.112 \\
5.164\end{array}$ & $\begin{array}{l}5.065 \\
5.117 \\
5.169\end{array}$ & $\begin{array}{l}5.070 \\
5.122 \\
5.174\end{array}$ & $\begin{array}{l}5.075 \\
5.127 \\
5.179\end{array}$ & $\begin{array}{l}5.080 \\
5.132 \\
5.185\end{array}$ & $\begin{array}{l}5.086 \\
5.138 \\
5.190\end{array}$ \\
\hline 1900 & 5.195 & 5.200 & 5.206 & 5.211 & 5.216 & 5.221 & 5.226 & 5.232 & 5.237 & 5.242 \\
\hline $\begin{array}{l}1970 \\
1980 \\
1990\end{array}$ & $\begin{array}{l}5.566 \\
5.620 \\
.5 .674\end{array}$ & $\begin{array}{l}5.571 \\
5.625 \\
5.679\end{array}$ & $\begin{array}{l}5.577 \\
6.631 \\
5.685\end{array}$ & $\begin{array}{l}5.582 \\
5.636 \\
5.690\end{array}$ & $\begin{array}{l}5.588 \\
5.641 \\
5.695\end{array}$ & $\begin{array}{l}5.593 \\
5.647 \\
5.701\end{array}$ & $\begin{array}{l}5.598 \\
5.652 \\
5.706\end{array}$ & $\begin{array}{l}5.604 \\
5.658 \\
5.712\end{array}$ & $\begin{array}{l}5.609 \\
5.663 \\
5.717\end{array}$ & $\begin{array}{l}5.614 \\
5.668 \\
5.723\end{array}$ \\
\hline 2000 & 5.728 & 5.733 & 5.739 & 5.744 & 5.750 & 5.755 & 5.761 & 5.766 & 5.771 & 5.777 \\
\hline $\begin{array}{l}2010 \\
2020 \\
2030\end{array}$ & $\begin{array}{l}5.782 \\
5.837 \\
5.891\end{array}$ & $\begin{array}{l}5.788 \\
5.842 \\
5.897\end{array}$ & $\begin{array}{l}5.793 \\
5.848 \\
5.902\end{array}$ & $\begin{array}{l}5.799 \\
5.853 \\
5.908\end{array}$ & $\begin{array}{l}5.804 \\
5.859 \\
5.913\end{array}$ & $\begin{array}{l}5.809 \\
5.864 \\
5.919\end{array}$ & $\begin{array}{l}5.815 \\
5.870 \\
5.924\end{array}$ & $\begin{array}{l}5.820 \\
5.875 \\
5.930\end{array}$ & $\begin{array}{l}5.826 \\
5.880 \\
5.935\end{array}$ & $\begin{array}{l}5.831 \\
5.886 \\
5.941\end{array}$ \\
\hline $\begin{array}{l}2040 \\
2050 \\
2060\end{array}$ & $\begin{array}{l}5.946 \\
6.001 \\
6.056\end{array}$ & $\begin{array}{l}5.952 \\
6.007 \\
6.062\end{array}$ & $\begin{array}{l}5.957 \\
6.012 \\
6.068\end{array}$ & $\begin{array}{l}5.963 \\
6.018 \\
6.073\end{array}$ & $\begin{array}{l}5.968 \\
6.023 \\
6.079\end{array}$ & $\begin{array}{l}5.974 \\
6.029 \\
6.084\end{array}$ & $\begin{array}{l}5.979 \\
6.034 \\
6.090\end{array}$ & $\begin{array}{l}5.985 \\
6.040 \\
6.095\end{array}$ & $\begin{array}{l}5.990 \\
6.045 \\
6.101\end{array}$ & $\begin{array}{l}5.996 \\
6.051 \\
6.106\end{array}$ \\
\hline $\begin{array}{l}2070 \\
2080 \\
2090\end{array}$ & $\begin{array}{l}6.112 \\
6.167 \\
6.223\end{array}$ & $\begin{array}{l}6.117 \\
6.173 \\
6.229\end{array}$ & $\begin{array}{l}6.123 \\
6.178 \\
6.234\end{array}$ & $\begin{array}{l}6.128 \\
6.184 \\
6.240\end{array}$ & $\begin{array}{l}6.134 \\
6.190 \\
6.245\end{array}$ & $\begin{array}{l}6.140 \\
6.195 \\
6.251\end{array}$ & $\begin{array}{l}6.145 \\
6.201 \\
6.257\end{array}$ & $\begin{array}{l}6.151 \\
6.206 \\
6.262\end{array}$ & $\begin{array}{l}6.156 \\
6.212 \\
6.268\end{array}$ & $\begin{array}{l}6.162 \\
6.217 \\
6.273\end{array}$ \\
\hline
\end{tabular}


Table 3A Platinum-30 percent Rhodium versus Platinum-6 Percent Rhodium Thermocouples-Continued

(Temperatures in Degrees F. Electromotive Force in Absolute Millivolts. Reference Junctions at $32^{\circ} \mathrm{F}$.)

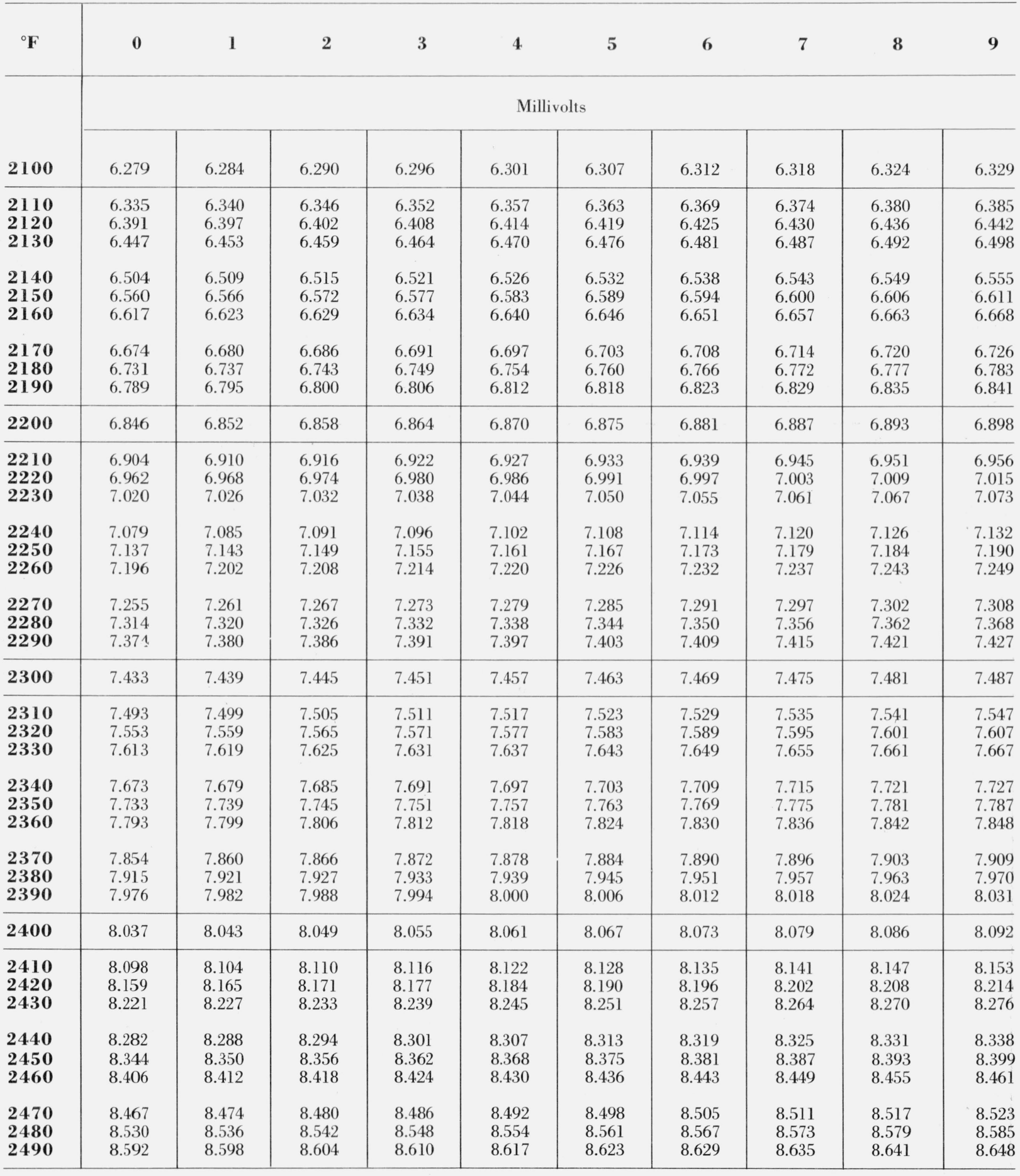


TABle 3A Platinum-30 percent Rhodium versus Platinum-6 Percent Rhodium Thermocouples-Continued (Temperatures in Degrees F. Electromotive Force in Absolute Millivolts. Reference Junctions at $32^{\circ} \mathrm{F}$.)

\begin{tabular}{|c|c|c|c|c|c|c|c|c|c|c|}
\hline \multirow[b]{2}{*}{2500} & 0 & 1 & 2 & 3 & 4 & 5 & 6 & 7 & 8 & 9 \\
\hline & 8.654 & 8.660 & 8.666 & 8.673 & 8.679 & 8.685 & 8.691 & 8.698 & 8.704 & 8.710 \\
\hline $\begin{array}{l}2540 \\
2550 \\
2560\end{array}$ & $\begin{array}{l}8.904 \\
8.967 \\
9.030\end{array}$ & $\begin{array}{l}8.910 \\
8.973 \\
9.036\end{array}$ & $\begin{array}{l}8.917 \\
8.979 \\
9.042\end{array}$ & $\begin{array}{l}8.923 \\
8.986 \\
9.049\end{array}$ & $\begin{array}{l}8.929 \\
8.992 \\
9.055\end{array}$ & $\begin{array}{l}8.935 \\
8.998 \\
9.061\end{array}$ & $\begin{array}{l}8.942 \\
9.005 \\
9.068\end{array}$ & $\begin{array}{l}8.948 \\
9.011 \\
9.074\end{array}$ & $\begin{array}{l}8.954 \\
9.017 \\
9.080\end{array}$ & $\begin{array}{l}8.961 \\
9.023 \\
9.086\end{array}$ \\
\hline $\begin{array}{l}2610 \\
2620 \\
2630\end{array}$ & $\begin{array}{l}9.346 \\
9.409 \\
9.473\end{array}$ & $\begin{array}{l}9.352 \\
9.415 \\
9.479\end{array}$ & $\begin{array}{l}9.358 \\
9.422 \\
9.485\end{array}$ & $\begin{array}{l}9.365 \\
9.428 \\
9.492\end{array}$ & $\begin{array}{l}9.371 \\
9.434 \\
9.498\end{array}$ & $\begin{array}{l}9.377 \\
9.441 \\
9.504\end{array}$ & $\begin{array}{l}9.384 \\
9.447 \\
9.511\end{array}$ & $\begin{array}{l}9.390 \\
9.453 \\
9.517\end{array}$ & $\begin{array}{l}9.396 \\
9.460 \\
9.523\end{array}$ & $\begin{array}{l}9.403 \\
9.466 \\
9.530\end{array}$ \\
\hline $\begin{array}{l}2640 \\
2650 \\
2660\end{array}$ & $\begin{array}{l}9.536 \\
9.600 \\
9.663\end{array}$ & $\begin{array}{l}9.542 \\
9.606 \\
9.670\end{array}$ & $\begin{array}{l}9.549 \\
9.612 \\
9.676\end{array}$ & $\begin{array}{l}9.555 \\
9.619 \\
9.683\end{array}$ & $\begin{array}{l}9.562 \\
9.625 \\
9.689\end{array}$ & $\begin{array}{l}9.568 \\
9.632 \\
9.695\end{array}$ & $\begin{array}{l}9.574 \\
9.638 \\
9.702\end{array}$ & $\begin{array}{l}9.581 \\
9.644 \\
9.708\end{array}$ & $\begin{array}{l}9.587 \\
9.651 \\
9.714\end{array}$ & $\begin{array}{l}9.593 \\
9.657 \\
9.721\end{array}$ \\
\hline $\begin{array}{l}2670 \\
2680 \\
2690\end{array}$ & $\begin{array}{l}9.727 \\
9.791 \\
9.855\end{array}$ & $\begin{array}{l}9.734 \\
9.797 \\
9.861\end{array}$ & $\begin{array}{l}9.740 \\
9.804 \\
9.868\end{array}$ & $\begin{array}{l}9.746 \\
9.810 \\
9.874\end{array}$ & $\begin{array}{l}9.753 \\
9.817 \\
9.881\end{array}$ & $\begin{array}{l}9.759 \\
9.823 \\
9.887\end{array}$ & $\begin{array}{l}9.766 \\
9.829 \\
9.893\end{array}$ & $\begin{array}{l}9.772 \\
9.836 \\
9.900\end{array}$ & $\begin{array}{l}9.778 \\
9.842 \\
9.906\end{array}$ & $\begin{array}{l}9.785 \\
9.849 \\
9.913\end{array}$ \\
\hline 2700 & 9.919 & 9.925 & 9.932 & 9.938 & 9.945 & 9.951 & 9.957 & 9.964 & 9.970 & 9.977 \\
\hline $\begin{array}{l}2770 \\
2780 \\
2790\end{array}$ & $\begin{array}{l}10.368 \\
10.433 \\
10.497\end{array}$ & $\begin{array}{l}10.375 \\
10.439 \\
10.504\end{array}$ & $\begin{array}{l}10.381 \\
10.446 \\
10.510\end{array}$ & $\begin{array}{l}10.388 \\
10.452 \\
10.517\end{array}$ & $\begin{array}{l}10.394 \\
10.459 \\
10.523\end{array}$ & $\begin{array}{l}10.401 \\
10.465 \\
10.529\end{array}$ & $\begin{array}{l}10.407 \\
10.471 \\
10.536\end{array}$ & $\begin{array}{l}10.413 \\
10.478 \\
10.542\end{array}$ & $\begin{array}{l}10.420 \\
10.484 \\
10.549\end{array}$ & $\begin{array}{l}10.426 \\
10.491 \\
10.555\end{array}$ \\
\hline 2800 & 10.562 & 10.568 & 10.575 & 10.581 & 10.587 & 10.594 & 10.600 & 10.607 & 10.613 & 10.620 \\
\hline $\begin{array}{l}2810 \\
2820 \\
2830\end{array}$ & $\begin{array}{l}10.626 \\
10.691 \\
10.755\end{array}$ & $\begin{array}{l}10.633 \\
10.697 \\
10.762\end{array}$ & $\begin{array}{l}10.639 \\
10.704 \\
10.768\end{array}$ & $\begin{array}{l}10.646 \\
10.710 \\
10.775\end{array}$ & $\begin{array}{l}10.652 \\
10.717 \\
10.781\end{array}$ & $\begin{array}{l}10.658 \\
10.723 \\
10.788\end{array}$ & $\begin{array}{l}10.665 \\
10.729 \\
10.794\end{array}$ & $\begin{array}{l}10.671 \\
10.736 \\
10.801\end{array}$ & $\begin{array}{l}10.678 \\
10.742 \\
10.807\end{array}$ & $\begin{array}{l}10.684 \\
10.749 \\
10.813\end{array}$ \\
\hline $\begin{array}{l}2840 \\
2850 \\
2860\end{array}$ & $\begin{array}{l}10.820 \\
10.885 \\
10.949\end{array}$ & $\begin{array}{l}10.826 \\
10.891 \\
10.956\end{array}$ & $\begin{array}{l}10.833 \\
10.898 \\
10.962\end{array}$ & $\begin{array}{l}10.839 \\
10.904 \\
10.969\end{array}$ & $\begin{array}{l}10.846 \\
10.910 \\
10.975\end{array}$ & $\begin{array}{l}10.852 \\
10.917 \\
10.982\end{array}$ & $\begin{array}{l}10.859 \\
10.923 \\
10.988\end{array}$ & $\begin{array}{l}10.865 \\
10.930 \\
10.995\end{array}$ & $\begin{array}{l}10.872 \\
10.936 \\
11.001\end{array}$ & $\begin{array}{l}10.878 \\
10.943 \\
11.007\end{array}$ \\
\hline $\begin{array}{l}2870 \\
2880 \\
2890\end{array}$ & $\begin{array}{l}11.014 \\
11.079 \\
11.143\end{array}$ & $\begin{array}{l}11.020 \\
11.085 \\
11.150\end{array}$ & $\begin{array}{l}11.027 \\
11.092 \\
11.156\end{array}$ & $\begin{array}{l}11.033 \\
11.098 \\
11.163\end{array}$ & $\begin{array}{l}11.040 \\
11.105 \\
11.169\end{array}$ & $\begin{array}{l}11.046 \\
11.111 \\
11.176\end{array}$ & $\begin{array}{l}11.053 \\
11.118 \\
11.182\end{array}$ & $\begin{array}{l}11.059 \\
11.124 \\
11.189\end{array}$ & $\begin{array}{l}11.066 \\
11.130 \\
11.195\end{array}$ & $\begin{array}{l}11.072 \\
11.137 \\
11.202\end{array}$ \\
\hline
\end{tabular}


Table 3A Platinum-30 percent Rhodium versus Platinum-6 Percent Rhodium Thermocouples-Continued (Temperatures in Degrees F. Electromotive Force in Absolute Millivolts. Reference Junctions at $32{ }^{\circ} \mathrm{F}$.)

\begin{tabular}{|c|c|c|c|c|c|c|c|c|c|c|}
\hline${ }^{\circ} \mathbf{F}$ & O & 1 & 2 & 3 & 4 & 5 & 6 & 7 & 8 & 9 \\
\hline \multirow[b]{2}{*}{2900} & \multicolumn{10}{|c|}{ Millivolts } \\
\hline & 11.208 & 11.215 & 11.221 & 11.228 & 11.234 & 11.241 & 11.247 & 11.254 & 11.260 & 11.266 \\
\hline $\begin{array}{l}2910 \\
2920 \\
2930\end{array}$ & $\begin{array}{l}11.273 \\
11.338 \\
11.4 .03\end{array}$ & $\begin{array}{l}11.279 \\
11.344 \\
11.409\end{array}$ & $\begin{array}{l}11.286 \\
11.351 \\
11.416\end{array}$ & $\begin{array}{l}11.292 \\
11.357 \\
11.422\end{array}$ & $\begin{array}{l}11.299 \\
11.364 \\
11.429\end{array}$ & $\begin{array}{l}11.305 \\
11.370 \\
11.435\end{array}$ & $\begin{array}{l}11.312 \\
11.377 \\
11.441\end{array}$ & $\begin{array}{l}11.318 \\
11.383 \\
11.448\end{array}$ & $\begin{array}{l}11.325 \\
11.390 \\
11.454\end{array}$ & $\begin{array}{l}11.331 \\
11.396 \\
11.461\end{array}$ \\
\hline $\begin{array}{l}2940 \\
2950 \\
2960\end{array}$ & $\begin{array}{l}11.467 \\
11.532 \\
11.597\end{array}$ & $\begin{array}{l}11.474 \\
11.539 \\
11.604\end{array}$ & $\begin{array}{l}11.480 \\
11.545 \\
11.610\end{array}$ & $\begin{array}{l}11.487 \\
11.552 \\
11.617\end{array}$ & $\begin{array}{l}11.493 \\
11.558 \\
11.623\end{array}$ & $\begin{array}{l}11.500 \\
11.565 \\
11.530\end{array}$ & $\begin{array}{l}11.506 \\
11.571 \\
11.636\end{array}$ & $\begin{array}{l}11.513 \\
11.578 \\
11.642\end{array}$ & $\begin{array}{l}11.519 \\
11.584 \\
11.649\end{array}$ & $\begin{array}{l}11.526 \\
11.591 \\
11.655\end{array}$ \\
\hline $\begin{array}{l}2970 \\
2980 \\
2990\end{array}$ & $\begin{array}{l}11.662 \\
11.727 \\
11.792\end{array}$ & $\begin{array}{l}11.668 \\
11.733 \\
11.798\end{array}$ & $\begin{array}{l}11.675 \\
11.740 \\
11.805\end{array}$ & $\begin{array}{l}11.681 \\
11.746 \\
11.811\end{array}$ & $\begin{array}{l}11.688 \\
11.753 \\
11.818\end{array}$ & $\begin{array}{l}11.694 \\
11.759 \\
11.824\end{array}$ & $\begin{array}{l}11.701 \\
11.766 \\
11.831\end{array}$ & $\begin{array}{l}11.707 \\
11.772 \\
11.837\end{array}$ & $\begin{array}{l}11.714 \\
11.779 \\
11.844\end{array}$ & $\begin{array}{l}11.720 \\
11.785 \\
11.850\end{array}$ \\
\hline 3000 & 11.857 & 11.863 & 11.869 & 11.876 & 11.882 & 11.889 & 11.895 & 11.902 & 11.908 & 11.915 \\
\hline $\begin{array}{l}3010 \\
3020 \\
3030\end{array}$ & $\begin{array}{l}11.921 \\
11.986 \\
12.051\end{array}$ & $\begin{array}{l}11.928 \\
11.993 \\
12.058\end{array}$ & $\begin{array}{l}11.934 \\
11.999 \\
12.064\end{array}$ & $\begin{array}{l}11.941 \\
12.006 \\
12.071\end{array}$ & $\begin{array}{l}11.947 \\
12.012 \\
12.077\end{array}$ & $\begin{array}{l}11.954 \\
12.019 \\
12.084\end{array}$ & $\begin{array}{l}11.960 \\
12.025 \\
12.090\end{array}$ & $\begin{array}{l}11.967 \\
12.032 \\
12.096\end{array}$ & $\begin{array}{l}11.973 \\
12.038 \\
12.103\end{array}$ & $\begin{array}{l}11.980 \\
12.045 \\
12.109\end{array}$ \\
\hline $\begin{array}{l}3040 \\
3050 \\
3060\end{array}$ & $\begin{array}{l}12.116 \\
12.181 \\
12.246\end{array}$ & $\begin{array}{l}12.122 \\
12.187 \\
12.252\end{array}$ & $\begin{array}{l}12.129 \\
12.194 \\
12.259\end{array}$ & $\begin{array}{l}12.135 \\
12.200 \\
12.265\end{array}$ & $\begin{array}{l}12.142 \\
12.207 \\
12.272\end{array}$ & $\begin{array}{l}12.148 \\
12.213 \\
12.278\end{array}$ & $\begin{array}{l}12.155 \\
12.220 \\
12.285\end{array}$ & $\begin{array}{l}12.161 \\
12.226 \\
12.291\end{array}$ & $\begin{array}{l}12.168 \\
12.233 \\
12.297\end{array}$ & $\begin{array}{l}12.174 \\
12.239 \\
12.304\end{array}$ \\
\hline $\begin{array}{l}3070 \\
3080 \\
3090\end{array}$ & $\begin{array}{l}12.310 \\
12.375 \\
12.440\end{array}$ & $\begin{array}{l}12.317 \\
12.382 \\
12.447\end{array}$ & $\begin{array}{l}12.323 \\
12.388 \\
12.453\end{array}$ & $\begin{array}{l}12.330 \\
12.395 \\
12.459\end{array}$ & $\begin{array}{l}12.336 \\
12.401 \\
12.466\end{array}$ & $\begin{array}{l}12.343 \\
12.408 \\
12.472\end{array}$ & $\begin{array}{l}12.349 \\
12.414 \\
12.479\end{array}$ & $\begin{array}{l}12.356 \\
12.421 \\
12.485\end{array}$ & $\begin{array}{l}12.362 \\
12.427 \\
12.492\end{array}$ & $\begin{array}{l}12.369 \\
12.434 \\
12.498\end{array}$ \\
\hline 3100 & 12.505 & 12.511 & 12.518 & 12.524 & 12.531 & 12.537 & 12.544 & 12.550 & 12.557 & 12.563 \\
\hline $\begin{array}{l}3110 \\
3120 \\
3130\end{array}$ & $\begin{array}{l}12.570 \\
12.634 \\
12.699\end{array}$ & $\begin{array}{l}12.576 \\
12.641 \\
12.706\end{array}$ & $\begin{array}{l}12.583 \\
12.647 \\
12.712\end{array}$ & $\begin{array}{l}12.589 \\
12.654 \\
12.719\end{array}$ & $\begin{array}{l}12.596 \\
12.660 \\
12.725\end{array}$ & $\begin{array}{l}12.602 \\
12.667 \\
12.731\end{array}$ & $\begin{array}{l}12.608 \\
12.673 \\
12.738\end{array}$ & $\begin{array}{l}12.615 \\
12.680 \\
12.744\end{array}$ & $\begin{array}{l}12.621 \\
12.686 \\
12.751\end{array}$ & $\begin{array}{l}12.628 \\
12.693 \\
12.757\end{array}$ \\
\hline $\begin{array}{l}3140 \\
3150 \\
3160\end{array}$ & $\begin{array}{l}12.764 \\
12.829 \\
12.893\end{array}$ & $\begin{array}{l}12.770 \\
12.835 \\
12.900\end{array}$ & $\begin{array}{l}12.777 \\
12.841 \\
12.906\end{array}$ & $\begin{array}{l}12.783 \\
12.848 \\
12.913\end{array}$ & $\begin{array}{l}12.790 \\
12.854 \\
12.919\end{array}$ & $\begin{array}{l}12.796 \\
12.861 \\
12.926\end{array}$ & $\begin{array}{l}12.803 \\
12.867 \\
12.932\end{array}$ & $\begin{array}{l}12.809 \\
12.874 \\
12.938\end{array}$ & $\begin{array}{l}12.816 \\
12.880 \\
12.945\end{array}$ & $\begin{array}{l}12.822 \\
12.887 \\
12.951\end{array}$ \\
\hline $\begin{array}{l}3170 \\
3180 \\
3190\end{array}$ & $\begin{array}{l}12.958 \\
13.022 \\
13.087\end{array}$ & $\begin{array}{l}12.964 \\
13.029 \\
13.093\end{array}$ & $\begin{array}{l}12.971 \\
13.035 \\
13.100\end{array}$ & $\begin{array}{l}12.977 \\
13.042 \\
13.106\end{array}$ & $\begin{array}{l}12.984 \\
13.048 \\
13.113\end{array}$ & $\begin{array}{l}12.990 \\
13.055 \\
13.119\end{array}$ & $\begin{array}{l}12.997 \\
13.061 \\
13.126\end{array}$ & $\begin{array}{l}13.003 \\
13.068 \\
13.132\end{array}$ & $\begin{array}{l}13.010 \\
13.074 \\
13.139\end{array}$ & $\begin{array}{l}13.016 \\
13.081 \\
13.145\end{array}$ \\
\hline 3200 & 13.152 & 13.158 & 13.165 & 13.171 & 13.177 & 13.184 & 13.190 & 13.197 & 13.203 & 13.210 \\
\hline $\begin{array}{l}3210 \\
3220 \\
3230\end{array}$ & $\begin{array}{l}13.216 \\
13.281 \\
13.345\end{array}$ & $\begin{array}{l}13.223 \\
13.287 \\
13.352\end{array}$ & $\begin{array}{l}13.229 \\
13.294 \\
13.358\end{array}$ & $\begin{array}{l}13.235 \\
13.300 \\
13.364\end{array}$ & $\begin{array}{l}13.242 \\
13.306 \\
13.371\end{array}$ & $\begin{array}{l}13.248 \\
13.313 \\
13.377\end{array}$ & $\begin{array}{l}13.255 \\
13.319 \\
13.384\end{array}$ & $\begin{array}{l}13.261 \\
13.326 \\
13.390\end{array}$ & $\begin{array}{l}13.268 \\
13.332 \\
13.397\end{array}$ & $\begin{array}{l}13.274 \\
13.339 \\
13.403\end{array}$ \\
\hline $\begin{array}{l}3240 \\
3250 \\
3260\end{array}$ & $\begin{array}{l}13.410 \\
13.474 \\
13.538\end{array}$ & $\begin{array}{l}13.416 \\
13.480 \\
13.545\end{array}$ & $\begin{array}{l}13.422 \\
13.487 \\
13.551\end{array}$ & $\begin{array}{l}13.429 \\
13.493 \\
13.558\end{array}$ & $\begin{array}{l}13.435 \\
13.500 \\
13.564\end{array}$ & $\begin{array}{l}13.442 \\
13.506 \\
13.570\end{array}$ & $\begin{array}{l}13.448 \\
13.513 \\
13.577\end{array}$ & $\begin{array}{l}13.455 \\
13.519 \\
13.583\end{array}$ & $\begin{array}{l}13.461 \\
13.525 \\
13.590\end{array}$ & $\begin{array}{l}13.468 \\
13.532 \\
13.596\end{array}$ \\
\hline $\begin{array}{l}3270 \\
3280 \\
3290\end{array}$ & $\begin{array}{l}13.603 \\
13.667 \\
13.731\end{array}$ & $\begin{array}{l}13.609 \\
13.673 \\
13.738\end{array}$ & $\begin{array}{l}13.615 \\
13.680 \\
13.744\end{array}$ & $\begin{array}{l}13.622 \\
13.686 \\
13.750\end{array}$ & $\begin{array}{l}13.628 \\
13.693 \\
13.757\end{array}$ & $\begin{array}{l}13.635 \\
13.699 \\
13.763\end{array}$ & $\begin{array}{l}13.641 \\
13.705 \\
13.770\end{array}$ & $\begin{array}{l}13.648 \\
13.712 \\
13.776\end{array}$ & $\begin{array}{l}13.654 \\
13.718 \\
13.783\end{array}$ & $\begin{array}{l}13.660 \\
13.725 \\
13.789\end{array}$ \\
\hline 3300 & 13.795 & 13.802 & 13.808 & 13.815 & 13.821 & 13.827 & 13.834 & 13.840 & 13.847 & \\
\hline
\end{tabular}


TABle 4A. Platinum-30 percent Rhodium versus Platinum-6 Percent Rhodium Thermocouples (Electromotive Force in Absolute Millivolts. Temperatures in Degrees F. Reference Junctions at $32^{\circ} \mathrm{F}$.)

\begin{tabular}{|c|c|c|c|c|c|c|c|c|c|c|}
\hline Millivolts & 0.000 & 0.010 & 0.020 & 0.030 & 0.040 & 0.050 & 0.060 & 0.070 & 0.080 & 0.090 \\
\hline & \multicolumn{10}{|c|}{ Degrees F } \\
\hline 0. & 32.0 & 153.2 & 182.2 & 205.1 & 224.8 & 242.3 & 258.2 & 272.8 & 286.5 & 299.4 \\
\hline 0.100 & 311.7 & 323.3 & 334.5 & 345.2 & 355.5 & 365.5 & 375.2 & 384.5 & 393.7 & 402.5 \\
\hline $\begin{array}{l}0.200 \\
0.300 \\
0.400\end{array}$ & $\begin{array}{l}411.2 \\
488.3 \\
553.7\end{array}$ & $\begin{array}{l}419.6 \\
495.2 \\
559.7\end{array}$ & $\begin{array}{l}427.9 \\
502.1 \\
565.8\end{array}$ & $\begin{array}{l}435.9 \\
508.9 \\
571.7\end{array}$ & $\begin{array}{l}443.8 \\
515.5 \\
577.6\end{array}$ & $\begin{array}{l}451.6 \\
522.1 \\
583.4\end{array}$ & $\begin{array}{l}459.2 \\
528.6 \\
589.1\end{array}$ & $\begin{array}{l}466.6 \\
535.0 \\
594.8\end{array}$ & $\begin{array}{l}474.0 \\
541.3 \\
600.5\end{array}$ & $\begin{array}{l}481.2 \\
547.5 \\
606.0\end{array}$ \\
\hline $\begin{array}{l}0.500 \\
0.600 \\
0.700\end{array}$ & $\begin{array}{l}611.6 \\
664.2 \\
712.7\end{array}$ & $\begin{array}{l}617.0 \\
669.2 \\
717.4\end{array}$ & $\begin{array}{l}622.5 \\
674.2 \\
722.0\end{array}$ & $\begin{array}{l}627.8 \\
679.1 \\
726.6\end{array}$ & $\begin{array}{l}633.2 \\
684.0 \\
731.2\end{array}$ & $\begin{array}{l}638.4 \\
688.9 \\
735.7\end{array}$ & $\begin{array}{l}643.7 \\
693.7 \\
740.3\end{array}$ & $\begin{array}{l}648.9 \\
698.5 \\
744.7\end{array}$ & $\begin{array}{l}654.0 \\
703.3 \\
749.2\end{array}$ & $\begin{array}{l}659.1 \\
708.0 \\
753.6\end{array}$ \\
\hline $\begin{array}{l}0.800 \\
0.900\end{array}$ & $\begin{array}{l}758.1 \\
800.8\end{array}$ & $\begin{array}{l}762.4 \\
804.9\end{array}$ & $\begin{array}{l}766.8 \\
809.1\end{array}$ & $\begin{array}{l}771.1 \\
813.2\end{array}$ & $\begin{array}{l}775.4 \\
817.3\end{array}$ & $\begin{array}{l}779.7 \\
821.3\end{array}$ & $\begin{array}{l}784.0 \\
825.4\end{array}$ & $\begin{array}{l}788.2 \\
829.4\end{array}$ & $\begin{array}{l}792.4 \\
833.4\end{array}$ & $\begin{array}{l}796.6 \\
837.4\end{array}$ \\
\hline 1.000 & 841.4 & 845.3 & 849.2 & 853.1 & 857.0 & 860.9 & 864.8 & 868.6 & 872.4 & 876.3 \\
\hline $\begin{array}{l}1.100 \\
1.200 \\
1.300\end{array}$ & $\begin{array}{l}880.0 \\
917.1 \\
952.8\end{array}$ & $\begin{array}{l}883.8 \\
920.7 \\
956.3\end{array}$ & $\begin{array}{l}887.6 \\
924.4 \\
959.8\end{array}$ & $\begin{array}{l}891.3 \\
928.0 \\
963.2\end{array}$ & $\begin{array}{l}895.1 \\
931.5 \\
966.7\end{array}$ & $\begin{array}{l}898.8 \\
935.1 \\
970.1\end{array}$ & $\begin{array}{l}902.5 \\
938.7 \\
973.6\end{array}$ & $\begin{array}{l}906.2 \\
942.2 \\
977.0\end{array}$ & $\begin{array}{l}909.8 \\
945.8 \\
980.4\end{array}$ & $\begin{array}{l}913.5 \\
949.3 \\
983.8\end{array}$ \\
\hline $\begin{array}{l}1.400 \\
1.500 \\
1.600\end{array}$ & $\begin{array}{r}987.2 \\
1020.5 \\
1052.8\end{array}$ & $\begin{array}{r}990.6 \\
1023.8 \\
1055.9\end{array}$ & $\begin{array}{r}993.9 \\
1027.0 \\
1059.1\end{array}$ & $\begin{array}{r}997.3 \\
1030.3 \\
1062.3\end{array}$ & $\begin{array}{l}1000.6 \\
1033.5 \\
1065.4\end{array}$ & $\begin{array}{l}1004.0 \\
1036.7 \\
1068.6\end{array}$ & $\begin{array}{l}1007.3 \\
1040.0 \\
1071.7\end{array}$ & $\begin{array}{l}1010.6 \\
1043.2 \\
1074.8\end{array}$ & $\begin{array}{l}1013.9 \\
1046.4 \\
1077.9\end{array}$ & $\begin{array}{l}1017.2 \\
1049.6 \\
1081.0\end{array}$ \\
\hline $\begin{array}{l}1.700 \\
1.800 \\
1.900\end{array}$ & $\begin{array}{l}1084.1 \\
1114.7 \\
1144.4\end{array}$ & $\begin{array}{l}1087.2 \\
1117.7 \\
1147.4\end{array}$ & $\begin{array}{l}1090.3 \\
1120.7 \\
1150.3\end{array}$ & $\begin{array}{l}1093.4 \\
1123.7 \\
1153.2\end{array}$ & $\begin{array}{l}1096.4 \\
1126.7 \\
1156.2\end{array}$ & $\begin{array}{l}1099.5 \\
1129.6 \\
1159.1\end{array}$ & $\begin{array}{l}1102.6 \\
1132.6 \\
1162.0\end{array}$ & $\begin{array}{l}1105.6 \\
1135.6 \\
1164.9\end{array}$ & $\begin{array}{l}1108.6 \\
1138.5 \\
1167.7\end{array}$ & $\begin{array}{l}1111.7 \\
1141.5 \\
1170.6\end{array}$ \\
\hline 2.000 & 1173.5 & 1176.4 & 1179.2 & 1182.1 & 1184.9 & 1187.8 & 1190.6 & 1193.5 & 1196.3 & 1199.1 \\
\hline $\begin{array}{l}2.100 \\
2.200 \\
2.300\end{array}$ & $\begin{array}{l}1201.9 \\
1229.7 \\
1257.0\end{array}$ & $\begin{array}{l}1204.7 \\
1232.5 \\
1259.7\end{array}$ & $\begin{array}{l}1207.5 \\
1235.2 \\
1262.4\end{array}$ & $\begin{array}{l}1210.3 \\
1238.0 \\
1265.0\end{array}$ & $\begin{array}{l}1213.1 \\
1240.7 \\
1267.7\end{array}$ & $\begin{array}{l}1215.9 \\
1243.4 \\
1270.4\end{array}$ & $\begin{array}{l}1218.7 \\
1246.1 \\
1273.1\end{array}$ & $\begin{array}{l}1221.4 \\
1248.9 \\
1275.7\end{array}$ & $\begin{array}{l}1224.2 \\
1251.6 \\
1278.4\end{array}$ & $\begin{array}{l}1227.0 \\
1254.3 \\
1281.0\end{array}$ \\
\hline $\begin{array}{l}2.400 \\
2.500 \\
2.600\end{array}$ & $\begin{array}{l}1283.7 \\
1309.9 \\
1335.7\end{array}$ & $\begin{array}{l}1286.3 \\
1312.5 \\
1338.2\end{array}$ & $\begin{array}{l}1289.0 \\
1315.1 \\
1340.8\end{array}$ & $\begin{array}{l}1291.6 \\
1317.7 \\
1343.3\end{array}$ & $\begin{array}{l}1294.2 \\
1320.3 \\
1345.9\end{array}$ & $\begin{array}{l}1296.9 \\
1322.9 \\
1348.4\end{array}$ & $\begin{array}{l}1299.5 \\
1325.4 \\
1350.9\end{array}$ & $\begin{array}{l}1302.1 \\
1328.0 \\
1353.5\end{array}$ & $\begin{array}{l}1304.7 \\
1330.6 \\
1356.0\end{array}$ & $\begin{array}{l}1307.3 \\
1333.1 \\
1358.5\end{array}$ \\
\hline $\begin{array}{l}2.700 \\
2.800 \\
2.900\end{array}$ & $\begin{array}{l}1361.0 \\
1385.9 \\
1410.5\end{array}$ & $\begin{array}{l}1363.5 \\
1388.4 \\
1412.9\end{array}$ & $\begin{array}{l}1366.0 \\
1390.9 \\
1415.3\end{array}$ & $\begin{array}{l}1368.5 \\
1393.3 \\
1417.7\end{array}$ & $\begin{array}{l}1371.0 \\
1395.8 \\
1420.2\end{array}$ & $\begin{array}{l}1373.5 \\
1398.2 \\
1422.6\end{array}$ & $\begin{array}{l}1376.0 \\
1400.7 \\
1425.0\end{array}$ & $\begin{array}{l}1378.5 \\
1403.1 \\
1427.4\end{array}$ & $\begin{array}{l}1381.0 \\
1405.6 \\
1429.8\end{array}$ & $\begin{array}{l}1383.5 \\
1408.0 \\
1432.2\end{array}$ \\
\hline 3.000 & 1434.6 & 1437.0 & 1439.4 & 1441.8 & 1444.2 & 1446.6 & 1448.9 & 1451.3 & 1453.7 & 1456.1 \\
\hline $\begin{array}{l}3.100 \\
3.200 \\
3.300\end{array}$ & $\begin{array}{l}1458.4 \\
1481.9 \\
1505.1\end{array}$ & $\begin{array}{l}1460.8 \\
1484.2 \\
1507.4\end{array}$ & $\begin{array}{l}1463.1 \\
1486.6 \\
1509.7\end{array}$ & $\begin{array}{l}1465.5 \\
1488.9 \\
1512.0\end{array}$ & $\begin{array}{l}1467.8 \\
1491.2 \\
1514.3\end{array}$ & $\begin{array}{l}1470.2 \\
1493.5 \\
1516.5\end{array}$ & $\begin{array}{l}1472.5 \\
1495.8 \\
1518.8\end{array}$ & $\begin{array}{l}1474.9 \\
1498.1 \\
1521.1\end{array}$ & $\begin{array}{l}1477.2 \\
1500.5 \\
1523.4\end{array}$ & $\begin{array}{l}1479.6 \\
1502.8 \\
1525.7\end{array}$ \\
\hline $\begin{array}{l}3.400 \\
\mathbf{3 . 5 0 0} \\
\mathbf{3 . 6 0 0}\end{array}$ & $\begin{array}{l}1528.0 \\
1550.6 \\
1572.9\end{array}$ & $\begin{array}{l}1530.2 \\
1552.8 \\
1575.1\end{array}$ & $\begin{array}{l}1532.5 \\
1555.1 \\
1577.3\end{array}$ & $\begin{array}{l}1534.8 \\
1557.3 \\
1579.6\end{array}$ & $\begin{array}{l}1537.0 \\
1559.5 \\
1581.8\end{array}$ & $\begin{array}{l}1539.3 \\
1561.8 \\
1584.0\end{array}$ & $\begin{array}{l}1541.6 \\
1564.0 \\
1586.2\end{array}$ & $\begin{array}{l}1543.8 \\
1566.2 \\
1588.4\end{array}$ & $\begin{array}{l}1546.1 \\
1568.5 \\
1590.6\end{array}$ & $\begin{array}{l}1548.3 \\
1570.7 \\
1592.8\end{array}$ \\
\hline $\begin{array}{l}3.700 \\
3.800 \\
3.900\end{array}$ & $\begin{array}{l}1595.0 \\
1616.8 \\
1638.4\end{array}$ & $\begin{array}{l}1597.2 \\
1619.0 \\
1640.6\end{array}$ & $\begin{array}{l}1599.4 \\
1621.2 \\
1642.7\end{array}$ & $\begin{array}{l}1601.6 \\
1623.3 \\
1644.8\end{array}$ & $\begin{array}{l}1603.7 \\
1625.5 \\
1647.0\end{array}$ & $\begin{array}{l}1605.9 \\
1627.6 \\
1649.1 \\
\end{array}$ & $\begin{array}{l}1608.1 \\
1629.8 \\
1651.3\end{array}$ & $\begin{array}{l}1610.3 \\
1632.0 \\
1653.4\end{array}$ & $\begin{array}{l}1612.5 \\
1634.1 \\
1655.5\end{array}$ & $\begin{array}{l}1614.6 \\
1636.3 \\
1657.6 \\
\end{array}$ \\
\hline
\end{tabular}


Table 4A. Platinum-30 percent Rhodium versus Platinum-6 Percent Rhodium Thermocouples-Continued (Electromotive Force in Absolute Millivolts. Temperatures in Degrees F. Reference Junctions at $32^{\circ} \mathrm{F}$.)

\begin{tabular}{|c|c|c|c|c|c|c|c|c|c|c|}
\hline Millivolts & 0.000 & 0.010 & 0.020 & 0.030 & 0.040 & 0.050 & 0.060 & 0.070 & 0.080 & 0.090 \\
\hline \multirow[b]{2}{*}{4.000} & \multicolumn{10}{|c|}{ Degrees F } \\
\hline & 1659.8 & 1661.9 & 1664.0 & 1666.1 & 1668.3 & 1670.4 & 1672.5 & 1674.6 & 1676.7 & 1678.8 \\
\hline 4.100 & 1680.9 & 1683.0 & 1685.1 & 1687.2 & 1689.3 & 1691.4 & 1693.5 & 1695.6 & 1697.7 & 1699.8 \\
\hline 4.200 & 1701.8 & 1703.9 & 1706.0 & 1708.1 & 1710.2 & 1712.2 & 1714.3 & 1716.4 & 1718.4 & 1720.5 \\
\hline 4.300 & 1722.6 & 1724.6 & 1726.7 & 1728.7 & 1730.8 & 1732.8 & 1734.9 & 1736.9 & 1739.0 & 1741.0 \\
\hline 4.400 & 1743.1 & 1745.1 & 1747.2 & 1749.2 & 1751.2 & 1753.3 & 1755.3 & 1757.3 & 1759.4 & 1761.4 \\
\hline 4.500 & 1763.4 & 1765.4 & 1767.5 & 1769.5 & 1771.5 & 1773.5 & 1775.5 & 1777.5 & 1779.5 & 1781.6 \\
\hline 4.600 & 1783.6 & 1785.6 & 1787.6 & 1789.6 & 1791.6 & 1793.6 & 1795.6 & 1797.6 & 1799.6 & 1801.5 \\
\hline 4.700 & 1803.5 & 1805.5 & 1807.5 & 1809.5 & 1811.5 & 1813.5 & 1815.4 & 1817.4 & 1819.4 & 1821.4 \\
\hline 4.800 & 1823.3 & 1825.3 & 1827.3 & 1829.2 & 1831.2 & 1833.2 & 1835.1 & 1837.1 & 1839.1 & 1841.0 \\
\hline 4.900 & 1843.0 & 1844.9 & 1846.9 & 1848.8 & 1850.8 & 1852.7 & 1854.7 & 1856.6 & 1858.6 & 1860.5 \\
\hline 5.000 & 1862.4 & 1864.4 & 1866.3 & 1868.3 & 1870.2 & 1872.1 & 1874.1 & 1876.0 & 1877.9 & 1879.8 \\
\hline 5.100 & 1881.8 & 1883.7 & 1885.6 & 1887.5 & 1889.5 & 1891.4 & 1893.3 & 1895.2 & 1897.1 & 1899.0 \\
\hline 5.200 & 1900.9 & 1902.9 & 1904.8 & 1906.7 & 1908.6 & 1910.5 & 1912.4 & 1914.3 & 1916.2 & 1918.1 \\
\hline 5.300 & 1920.0 & 1921.9 & 1923.8 & 1925.7 & 1927.6 & 1929.5 & 1931.3 & 1933.2 & 1935.1 & 1937.0 \\
\hline 5.400 & 1938.9 & 1940.8 & 1942.7 & 1944.5 & 1946.4 & 1948.3 & 1950.2 & 1952.0 & 1953.9 & 1955.8 \\
\hline 5.500 & 1957.7 & 1959.5 & 1961.4 & 1963.3 & 1965.1 & 1967.0 & 1968.9 & 1970.7 & 1972.6 & 1974.5 \\
\hline 5.600 & 1976.3 & 1978.2 & 1980.0 & 1981.9 & 1983.7 & 1985.6 & 1987.4 & 1989.3 & 1991.1 & 1993.0 \\
\hline 5.700 & 1994.8 & 1996.7 & 1998.5 & 2000.4 & 2002.2 & 2004.1 & 2005.9 & 2007.7 & 2009.6 & 2011.4 \\
\hline 5.800 & 2013.3 & 2015.1 & 2016.9 & 2018.8 & 2020.6 & 2022.4 & 2024.3 & 2026.1 & 2027.9 & 2029.7 \\
\hline 5.900 & 2031.6 & 2033.4 & 2035.2 & 2037.0 & 2038.9 & 2040.7 & 2042.5 & 2044.3 & 2046.1 & 2047.9 \\
\hline 6.000 & 2049.8 & 2051.6 & 2053.4 & 2055.2 & 2057.0 & 2058.8 & 2060.6 & 2062.4 & 2064.2 & 2066.1 \\
\hline 6.100 & 2067.9 & 2069.7 & 2071.5 & 2073.3 & 2075.1 & 2076.9 & 2078.7 & 2080.5 & 2082.3 & 2084.1 \\
\hline 6.200 & 2085.9 & 2087.7 & 2089.5 & 2091.2 & 2093.0 & 2094.8 & 2096.6 & 2098.4 & 2100.2 & 2102.0 \\
\hline 6.300 & 2103.8 & 2105.6 & 2107.3 & 2109.1 & 2110.9 & 2112.7 & 2114.5 & 2116.3 & 2118.0 & 2119.8 \\
\hline 6.400 & 2121.6 & 2123.4 & 2125.1 & 2126.9 & 2128.7 & 2130.5 & 2132.2 & 2134.0 & 2135.8 & 2137.6 \\
\hline 6.500 & 2139.3 & 2141.1 & 2142.9 & 2144.6 & 2146.4 & 2148.2 & 2149.9 & 2151.7 & 2153.5 & 2155.2 \\
\hline 6.600 & 2157.0 & 2158.7 & 2160.5 & 2162.3 & 2164.0 & 2165.8 & 2167.5 & 2169.3 & 2171.0 & 2172.8 \\
\hline 6.700 & 2174.5 & 2176.3 & 2178.0 & 2179.8 & 2181.5 & 2183.2 & 2185.0 & 2186.7 & 2188.5 & 2190.2 \\
\hline 6.800 & 2191.9 & 2193.7 & 2195.4 & 2197.2 & 2198.9 & 2200.6 & 2202.4 & 2204.1 & 2205.8 & 2207.5 \\
\hline 6.900 & 2209.3 & 2211.0 & 2212.7 & 2214.4 & 2216.2 & 2217.9 & 2219.6 & 2221.3 & 2223.0 & 2224.8 \\
\hline 7.000 & 2226.5 & 2228.2 & 2229.9 & 2231.6 & 2233.3 & 2235.1 & 2236.8 & 2238.5 & 2240.2 & 2241.9 \\
\hline 7.100 & 2243.6 & 2245.3 & 2247.0 & 2248.7 & 2250.4 & 2252.1 & 2253.8 & 2255.5 & 2257.2 & 2258.9 \\
\hline 7.200 & 2260.6 & 2262.3 & 2264.0 & 2265.7 & 2267.4 & 2269.1 & 2270.8 & 2272.5 & 2274.2 & 2275.9 \\
\hline 7.300 & 2277.6 & 2279.3 & 2281.0 & 2282.6 & 2284.3 & 2286.0 & 2287.7 & 2289.4 & 2291.1 & 2292.8 \\
\hline 7.400 & 2294.4 & 2296.1 & 2297.8 & 2299.5 & 2301.2 & 2302.8 & 2304.5 & 2306.2 & 2307.9 & 2309.5 \\
\hline 7.500 & 2311.2 & 2312.9 & 2314.6 & 2316.2 & 2317.9 & 2319.6 & 2321.2 & 2322.9 & 2324.6 & 2326.2 \\
\hline 7.600 & 2327.9 & 2329.6 & 2331.2 & 2332.9 & 2334.6 & 2336.2 & 2337.9 & 2339.6 & 2341.2 & 2342.9 \\
\hline 7.700 & 2344.5 & 2346.2 & 2347.9 & 2349.5 & 2351.2 & 2352.8 & 2354.5 & 2356.1 & 2357.8 & ․ 2359.4 \\
\hline 7.800 & 2361.1 & 2362.7 & 2364.4 & 2366.0 & 2367.7 & 2369.3 & 2371.0 & 2372.6 & 2374.3 & 2375.9 \\
\hline 7.900 & 2377.6 & 2379.2 & 2380.9 & 2382.5 & 2384.2 & 2385.8 & 2387.4 & 2389.1 & 2390.7 & 2392.4 \\
\hline
\end{tabular}


TABle 4A. Platinum-30 percent Rhodium versus Platinum-6 Percent Rhodium Thermocouples-Continued

(Electromotive Force in Absolute Millivolts. Temperatures in Degrees F. Reference Junctions at $32{ }^{\circ} \mathrm{F}$.)

\begin{tabular}{|c|c|c|c|c|c|c|c|c|c|c|}
\hline Millivolts & 0.000 & 0.010 & 0.020 & 0.030 & 0.040 & 0.050 & 0.060 & 0.070 & 0.080 & 0.090 \\
\hline & \multicolumn{10}{|c|}{ Degrees $\mathrm{F}$} \\
\hline 8.000 & 2394.0 & 2395.6 & 2397.3 & 2398.9 & 2400.6 & 2402.2 & 2403.8 & 2405.5 & 2407.1 & 2408.7 \\
\hline $\begin{array}{l}8.100 \\
8.200 \\
8.300\end{array}$ & $\begin{array}{l}2410.4 \\
2426.7 \\
2442.9\end{array}$ & $\begin{array}{l}2412.0 \\
2428.3 \\
2444.5\end{array}$ & $\begin{array}{l}2413.6 \\
2429.9 \\
2446.2\end{array}$ & $\begin{array}{l}2415.3 \\
2431.5 \\
2447.8\end{array}$ & $\begin{array}{l}2416.9 \\
2433.2 \\
2449.4\end{array}$ & $\begin{array}{l}2418.5 \\
2434.8 \\
2451.0\end{array}$ & $\begin{array}{l}2420.2 \\
2436.4 \\
2452.6\end{array}$ & $\begin{array}{l}2421.8 \\
2438.0 \\
2454.3\end{array}$ & $\begin{array}{l}2423.4 \\
2439.7 \\
2455.9\end{array}$ & $\begin{array}{l}2425.0 \\
2441.3 \\
2457.5\end{array}$ \\
\hline $\begin{array}{l}8.400 \\
8.500 \\
8.600\end{array}$ & $\begin{array}{l}2459.1 \\
2475.2 \\
2491.3\end{array}$ & $\begin{array}{l}2460.7 \\
2476.9 \\
2492.9\end{array}$ & $\begin{array}{l}2462.3 \\
2478.5 \\
2494.6\end{array}$ & $\begin{array}{l}2464.0 \\
2480.1 \\
2496.2\end{array}$ & $\begin{array}{l}2465.6 \\
2481.7 \\
2497.8\end{array}$ & $\begin{array}{l}2467.2 \\
2483.3 \\
2499.4\end{array}$ & $\begin{array}{l}2468.8 \\
2484.9 \\
2501.0\end{array}$ & $\begin{array}{l}2470.4 \\
2486.5 \\
2502.6\end{array}$ & $\begin{array}{l}2472.0 \\
2488.1 \\
2504.2\end{array}$ & $\begin{array}{l}2473.6 \\
2489.7 \\
2505.8\end{array}$ \\
\hline $\begin{array}{l}8.700 \\
8.800 \\
8.900\end{array}$ & $\begin{array}{l}2507.4 \\
2523.4 \\
2539.3\end{array}$ & $\begin{array}{l}2509.0 \\
2525.0 \\
2540.9\end{array}$ & $\begin{array}{l}2510.6 \\
2526.6 \\
2542.5\end{array}$ & $\begin{array}{l}2512.2 \\
2528.2 \\
2544.1\end{array}$ & $\begin{array}{l}2513.8 \\
2529.8 \\
2545.7\end{array}$ & $\begin{array}{l}2515.4 \\
2531.4 \\
2547.3\end{array}$ & $\begin{array}{l}2517.0 \\
2533.0 \\
2548.9\end{array}$ & $\begin{array}{l}2518.6 \\
2534.6 \\
2550.5\end{array}$ & $\begin{array}{l}2520.2 \\
2536.2 \\
2552.1\end{array}$ & $\begin{array}{l}2521.8 \\
2537.8 \\
2553.7\end{array}$ \\
\hline 9.000 & 2555.3 & 2556.9 & 2558.4 & 2560.0 & 2561.6 & 2563.2 & 2564.8 & 2566.4 & 2568.0 & 2569.6 \\
\hline $\begin{array}{l}9.100 \\
9.200 \\
9.300\end{array}$ & $\begin{array}{l}2571.1 \\
2587.0 \\
2602.8\end{array}$ & $\begin{array}{l}2572.7 \\
2588.6 \\
2604.4\end{array}$ & $\begin{array}{l}2574.3 \\
2590.2 \\
2606.0\end{array}$ & $\begin{array}{l}2575.9 \\
2591.7 \\
2607.5\end{array}$ & $\begin{array}{l}2577.5 \\
2593.3 \\
2609.1\end{array}$ & $\begin{array}{l}2579.1 \\
2594.9 \\
2610.7\end{array}$ & $\begin{array}{l}2580.7 \\
2596.5 \\
2612.3\end{array}$ & $\begin{array}{l}2582.2 \\
2598.1 \\
2613.9\end{array}$ & $\begin{array}{l}2583.8 \\
2599.6 \\
2615.4\end{array}$ & $\begin{array}{l}2585.4 \\
2601.2 \\
2617.0\end{array}$ \\
\hline $\begin{array}{l}9.400 \\
9.500 \\
9.600\end{array}$ & $\begin{array}{l}2618.6 \\
2634.3 \\
2650.0\end{array}$ & $\begin{array}{l}2620.2 \\
2635.9 \\
2651.6\end{array}$ & $\begin{array}{l}2621.7 \\
2637.5 \\
2653.2\end{array}$ & $\begin{array}{l}2623.3 \\
2639.0 \\
2654.8\end{array}$ & $\begin{array}{l}2624.9 \\
2640.6 \\
2656.3\end{array}$ & $\begin{array}{l}2626.5 \\
2642.2 \\
2657.9\end{array}$ & $\begin{array}{l}2628.0 \\
2643.8 \\
2659.5\end{array}$ & $\begin{array}{l}2629.6 \\
2645.3 \\
2661.0\end{array}$ & $\begin{array}{l}2631.2 \\
2646.9 \\
2662.6\end{array}$ & $\begin{array}{l}2632.8 \\
2648.5 \\
2664.2\end{array}$ \\
\hline $\begin{array}{l}9.700 \\
9.800 \\
9.900\end{array}$ & $\begin{array}{l}2665.7 \\
2681.4 \\
2697.0\end{array}$ & $\begin{array}{l}2667.3 \\
2683.0 \\
2698.6\end{array}$ & $\begin{array}{l}2668.9 \\
2684.5 \\
2700.2\end{array}$ & $\begin{array}{l}2670.4 \\
2686.1 \\
2701.7\end{array}$ & $\begin{array}{l}2672.0 \\
2687.7 \\
2703.3\end{array}$ & $\begin{array}{l}2673.6 \\
2689.2 \\
2704.8\end{array}$ & $\begin{array}{l}2675.1 \\
2690.8 \\
2706.4\end{array}$ & $\begin{array}{l}2676.7 \\
2692.3 \\
2708.0\end{array}$ & $\begin{array}{l}2678.3 \\
2693.9 \\
2709.5\end{array}$ & $\begin{array}{l}2679.8 \\
2695.5 \\
2711.1\end{array}$ \\
\hline 10.000 & 2712.7 & 2714.2 & 2715.8 & 2717.3 & 2718.9 & 2720.5 & 2722.0 & 2723.6 & 2725.1 & 2726.7 \\
\hline $\begin{array}{l}10.100 \\
10.200 \\
10.300\end{array}$ & $\begin{array}{l}2728.2 \\
2743.8 \\
2759.4\end{array}$ & $\begin{array}{l}2729.8 \\
2745.4 \\
2760.9\end{array}$ & $\begin{array}{l}2731.4 \\
2746.9 \\
2762.5\end{array}$ & $\begin{array}{l}2732.9 \\
2748.5 \\
2764.0\end{array}$ & $\begin{array}{l}2734.5 \\
2750.0 \\
2765.6\end{array}$ & $\begin{array}{l}2736.0 \\
2751.6 \\
2767.1\end{array}$ & $\begin{array}{l}2737.6 \\
2753.2 \\
2768.7\end{array}$ & $\begin{array}{l}2739.1 \\
2754.7 \\
2770.3\end{array}$ & $\begin{array}{l}2740.7 \\
2756.3 \\
2771.8\end{array}$ & $\begin{array}{l}2742.3 \\
2757.8 \\
2773.4\end{array}$ \\
\hline $\begin{array}{l}10.400 \\
10.500 \\
10.600\end{array}$ & $\begin{array}{l}2774.9 \\
2790.4 \\
2805.9\end{array}$ & $\begin{array}{l}2776.5 \\
2792.0 \\
2807.5\end{array}$ & $\begin{array}{l}2778.0 \\
2793.5 \\
2809.0\end{array}$ & $\begin{array}{l}2779.6 \\
2795.1 \\
2810.6\end{array}$ & $\begin{array}{l}2781.1 \\
2796.6 \\
2812.1\end{array}$ & $\begin{array}{l}2782.7 \\
2798.2 \\
2813.7\end{array}$ & $\begin{array}{l}2784.2 \\
2799.7 \\
2815.2\end{array}$ & $\begin{array}{l}2785.8 \\
2801.3 \\
2816.8\end{array}$ & $\begin{array}{l}2787.3 \\
2802.8 \\
2818.3\end{array}$ & $\begin{array}{l}2788.9 \\
2804.4 \\
2819.9\end{array}$ \\
\hline $\begin{array}{l}10.700 \\
10.800 \\
10.900\end{array}$ & $\begin{array}{l}2821.4 \\
2836.9 \\
2852.4\end{array}$ & $\begin{array}{l}2823.0 \\
2838.5 \\
2853.9\end{array}$ & $\begin{array}{l}2824.5 \\
2840.0 \\
2855.5\end{array}$ & $\begin{array}{l}2826.1 \\
2841.6 \\
2857.0\end{array}$ & $\begin{array}{l}2827.6 \\
2843.1 \\
2858.6\end{array}$ & $\begin{array}{l}2829.2 \\
2844.6 \\
2860.1\end{array}$ & $\begin{array}{l}2830.7 \\
2846.2 \\
1861.7\end{array}$ & $\begin{array}{l}2832.3 \\
2847.7 \\
2863.2\end{array}$ & $\begin{array}{l}2833.8 \\
2849.3 \\
2864.8\end{array}$ & $\begin{array}{l}2835.4 \\
2850.8 \\
2866.3\end{array}$ \\
\hline 11.000 & 2867.8 & 2869.4 & 2870.9 & 2872.5 & 2874.0 & 2875.6 & 2877.1 & 2878.7 & 2880.2 & 2881.7 \\
\hline $\begin{array}{l}11.100 \\
11.200 \\
11.300\end{array}$ & $\begin{array}{l}2883.3 \\
2898.7 \\
2914.2\end{array}$ & $\begin{array}{l}2884.8 \\
2900.3 \\
2915.7\end{array}$ & $\begin{array}{l}2886.4 \\
2901.8 \\
2917.3\end{array}$ & $\begin{array}{l}2887.9 \\
2903.4 \\
2918.8\end{array}$ & $\begin{array}{l}2889.5 \\
2904.9 \\
2920.3\end{array}$ & $\begin{array}{l}2891.0 \\
2906.5 \\
2921.9\end{array}$ & $\begin{array}{l}2892.6 \\
2908.0 \\
2923.4\end{array}$ & $\begin{array}{l}2894.1 \\
2909.5 \\
2925.0\end{array}$ & $\begin{array}{l}2895.6 \\
2911.1 \\
2926.5\end{array}$ & $\begin{array}{l}2897.2 \\
2912.6 \\
2928.1\end{array}$ \\
\hline $\begin{array}{l}11.400 \\
11.500 \\
11.600\end{array}$ & $\begin{array}{l}2929.6 \\
2945.0 \\
2960.4\end{array}$ & $\begin{array}{l}2931.1 \\
2946.6 \\
2962.0\end{array}$ & $\begin{array}{l}2932.7 \\
2948.1 \\
2963.5\end{array}$ & $\begin{array}{l}2934.2 \\
2949.7 \\
2965.1\end{array}$ & $\begin{array}{l}2935.8 \\
2951.2 \\
2966.6\end{array}$ & $\begin{array}{l}2937.3 \\
2952.7 \\
2968.2\end{array}$ & $\begin{array}{l}2938.9 \\
2954.3 \\
2969.7\end{array}$ & $\begin{array}{l}2940.4 \\
2955.8 \\
2971.2\end{array}$ & $\begin{array}{l}2941.9 \\
2957.4 \\
2972.8\end{array}$ & $\begin{array}{l}2943.5 \\
2958.9 \\
2974.3\end{array}$ \\
\hline $\begin{array}{l}11.700 \\
11.800 \\
11.900\end{array}$ & $\begin{array}{l}2975.9 \\
2991.3 \\
3006.7\end{array}$ & $\begin{array}{l}2977.4 \\
2992.8 \\
3008.2\end{array}$ & $\begin{array}{l}2979.0 \\
2994.4 \\
3009.8\end{array}$ & $\begin{array}{l}2980.5 \\
2995.9 \\
3011.3\end{array}$ & $\begin{array}{l}2982.0 \\
2997.5 \\
3012.9\end{array}$ & $\begin{array}{l}2983.6 \\
2999.0 \\
3014.4\end{array}$ & $\begin{array}{l}2985.1 \\
3000.5 \\
3016.0\end{array}$ & $\begin{array}{l}2986.7 \\
3002.1 \\
3017.5\end{array}$ & $\begin{array}{l}2988.2 \\
3003.6 \\
3019.0\end{array}$ & $\begin{array}{l}2989.7 \\
3005.2 \\
3020.6\end{array}$ \\
\hline
\end{tabular}


Table 4A. Platinum-30 percent Rhodium versus Platinum-6 Percent Rhodium Thermocouples-Continued (Electromotive Force in Absolute Millivolts. Temperatures in Degrees F. Reference Junctions at $32^{\circ} \mathrm{F}$

\begin{tabular}{|c|c|c|c|c|c|c|c|c|c|c|}
\hline Millivolts & 0.000 & 0.010 & 0.020 & 0.030 & 0.040 & 0.050 & 0.060 & 0.070 & 0.080 & 0.090 \\
\hline \multirow[b]{2}{*}{12.000} & \multicolumn{10}{|c|}{ Degrees F } \\
\hline & 3022.1 & 3023.7 & 3025.2 & 3026.7 & 3028.3 & 3029.8 & 3031.4 & 3032.9 & 3034.5 & 3036.0 \\
\hline 12.100 & 3037.5 & 3039.1 & 3040.6 & 3042.2 & 3043.7 & 3045.3 & 3046.8 & 3048.3 & 3049.9 & 3051.4 \\
\hline 12.200 & 3053.0 & 3054.5 & 3056.0 & 3057.6 & 3059.1 & 3060.7 & 3062.2 & 3063.8 & 3065.3 & 3066.8 \\
\hline 12.300 & 3068.4 & 3069.9 & 3071.5 & 3073.0 & 3074.6 & 3076.1 & 3077.6 & 3079.2 & 3080.7 & 3082.3 \\
\hline 12.400 & 3083.8 & 3085.4 & 3086.9 & 3088.4 & 3090.0 & 3091.5 & 3093.1 & 3094.6 & 3096.2 & 3097.7 \\
\hline 12.500 & 3099.3 & 3100.8 & 3102.3 & 3103.9 & 3105.4 & 3107.0 & 3108.5 & 3110.1 & 3111.6 & 3113.1 \\
\hline 12.600 & 3114.7 & 3116.2 & 3117.8 & 3119.3 & 3120.9 & 3122.4 & 3124.0 & 3125.5 & 3127.0 & 3128.6 \\
\hline 12.700 & 3130.1 & 3131.7 & 3133.2 & 3134.8 & 3136.3 & 3137.9 & 3139.4 & 3141.0 & 3142.5 & 3144.0 \\
\hline 12.800 & 3145.6 & 3147.1 & 3148.7 & 3150.2 & 3151.8 & 3153.3 & 3154.9 & 3156.4 & 3158.0 & 3159.5 \\
\hline 12.900 & 3161.1 & 3162.6 & 3164.1 & 3165.7 & 3167.2 & 3168.8 & 3170.3 & 3171.9 & 3173.4 & 3175.0 \\
\hline 13.000 & 3176.5 & 3178.1 & 3179.6 & 3181.2 & 3182.7 & 3184.3 & 3185.8 & 3187.4 & 3188.9 & 3190.5 \\
\hline 13.100 & 3192.0 & 3193.6 & 3195.1 & 3196.7 & 3198.2 & 3199.8 & 3201.3 & 3202.9 & 3204.4 & 3206.0 \\
\hline 13.200 & 3207.5 & 3209.0 & 3210.6 & 3212.1 & 3213.7 & 3215.3 & 3216.8 & 3218.4 & 3219.9 & 3221.5 \\
\hline 13.300 & 3223.0 & 3224.6 & 3226.1 & 3227.7 & 3229.2 & 3230.8 & 3232.3 & 3233.9 & 3235.4 & 3237.0 \\
\hline 13.400 & 3238.5 & 3240.1 & 3241.6 & 3243.2 & 3244.7 & 3246.3 & 3247.8 & 3249.4 & 3250.9 & 3252.5 \\
\hline 13.500 & 3254.0 & 3255.6 & 3257.2 & 3258.7 & 3260.3 & 3261.8 & 3263.4 & 3264.9 & 3266.5 & 3268.0 \\
\hline 13.600 & 3269.6 & 3271.1 & 3272.7 & 3274.3 & 3275.8 & 3277.4 & 3278.9 & 3280.5 & 3282.0 & 3283.6 \\
\hline 13.700 & 3285.1 & 3286.7 & 3288.3 & 3289.8 & 3291.4 & 3292.9 & 3294.5 & 3296.0 & 3297.6 & 3299.2 \\
\hline 13.800 & 3300.7 & 3302.3 & 3303.8 & 3305.4 & 3307.0 & & & & & \\
\hline
\end{tabular}

\section{References}

[1] H. Ehringer, Über die lebensdauer von ptrh-thermoelementen, Metall 8, 596 (1954).

[2] B. E. Walker, C. T. Ewing, and R. R. Miller, Thermoelectric instablility of some noble metal thermocouples at high temperatures, Rev. Sci. Instr. 33, 1029 (Oct. 1962).

[3] B. E. Walker, C. T. Ewing, and R. R. Miller. Study of the in stability of noble metal thermocouples in vacuum, Rev. Sci. Instr. 36, 601 (May 1965).

[4] R. C. Jewell, E. G. Knowles, and T. Land, High Temperature Thermocouple, Metal Ind (London) 87, 217, (1955).

[5] J. S. Acken. Some Physical Properties of Platinum-Rhodium Alloys, BS J. Res. 12, 249. (1934) (RP660).

[6] J. W. Hendricks and D. L. McElroy, High-temperature high vacuum thermocouple drift tests, presented at sec 2 . Sub IV of ASTM E-20 Committee. ASTM Meeting. Chicago, III. June 25, 1964.
[7] W. Obrowski and W. Prinz, Neu bestimmte grundwerte für die thermopaarkombination pt $30 \%$ rh-pt $6 \%$ rh. Arch. Eisenhüttenwesen 33, 1 (1962).

[8] G. W. Burns, Studies at NBS of the platinum-6\% rhodium versus platinum-30\% rhodium thermocouple-a preliminary report. presented at SAE meeting Sept. 23-27. 1963. Los Angeles. Calif., paper $750 \mathrm{~B}$.

[9] J. C. DeVos. Evaluation of the quality of a blackbody. Physica 20, 660 (1954).

[10] Section 3.2 of NBS Circ. 590. Methods of testing thermocouples and thermocouple materials.

111] D. B. Thomas, A furnace for thermocouple calibrations to 2.200 ${ }^{\circ} \mathrm{C}$, J. Res.. NBS 66C, No. 3, 255-260 (July-Sept.. 1962). 